UNIVERSIDADE DE BRASÍLIA

INSTITUTO DE PSICOLOGIA

PROGRAMA DE PÓS-GRADUAÇÃO EM PSICOLOGIA CLÍNICA E CULTURA - PPGPSiCC

PAULA OLIVEIRA SOBRAL

O Feminino e o Irrepresentável 
PAULA OLIVEIRA SOBRAL

\section{O Feminino e o Irrepresentável}

Tese apresentada ao Programa de Pósgraduação em Psicologia Clínica e Cultura da Universidade de Brasília como requisito à obtenção do título de Doutora em Psicologia.

Orientadora: Prof. ${ }^{\mathrm{a}}$ Dr $^{\mathrm{a}}$. Terezinha de Camargo Viana 


\section{O Feminino e o Irrepresentável}

Tese apresentada ao Programa de Pós-graduação em Psicologia clínica e cultura da Universidade de Brasília como requisito à obtenção do título de Doutora em Psicologia.

\section{Banca Examinadora:}

Presidente:

Prof $^{a}$. Dr ${ }^{\mathrm{a}}$. Terezinha de Camargo Viana

Universidade de Brasília - UnB

Membro:

Prof $f^{\mathrm{a}}$. Dr ${ }^{\mathrm{a}}$. Andréa Hortélio Fernandes

Universidade Federal da Bahia - UFBA

Membro:

Prof. Dr. Henrique Figueiredo Carneiro

Universidade de Pernambuco - UPE

Membro:

Prof ${ }^{a}$. Dr ${ }^{\mathrm{a}}$. Daniela Scheinkman Chatelard

Universidade de Brasília - UnB

Membro:

Prof $^{\mathrm{a}}$. Dra ${ }^{\mathrm{a}}$. Márcia Teresa Portela de Carvalho

Universidade de Brasília - UnB

Suplente:

Prof. Dr. Luiz Augusto Monnerat Celes

Universidade de Brasília - UnB 


\section{AGRADECIMENTOS}

À Prof ${ }^{a}$. Dr ${ }^{a}$ Terezinha de Camargo Viana, orientadora deste trabalho de Tese, agradeço pela aposta e confiança em meu percurso, pelo incentivo sempre presente, oferecendo oportunidades e caminhos acadêmicos. Divido com você o resultado deste trabalho que deixa marcas escritas em mim. Muito obrigada!

Aos professores Marie-Jean Sauret e Sidi Askofaré, por me receberem em estágio sanduíche na Université de Toulouse Jean Jaurès - França e pela possibilidade de dedicação intensa às leituras e elaborações psicanalíticas;

À CAPES - Coordenadoria e Aperfeiçoamento de Pessoal de Ensino Superior, por viabilizar a realização deste Doutorado;

Aos professores do Programa de Pós-Graduação em Psicologia Clínica e Cultura, em especial à Professora Eliana Lazarinni, pela abertura para o diálogo sempre e pela amizade, e à Professora Daniela Chatelard, pelas inspirações e identificações teóricas;

Aos professores da banca examinadora da qualificação, Prof ${ }^{a}$. Dra ${ }^{\mathrm{a}}$. Andréa Hortélio Fernandes, Prof ${ }^{\mathrm{a}}$. Dr ${ }^{\mathrm{a}}$. Angélica Bastos de F. R. Grimberg e Prof. Dr. Luiz Augusto Monnerat Celes, pelas preciosas contribuições que ressoaram na escrita deste trabalho. Bem como, ao Prof. Dr. Henrique Carneiro Ribeiro, a Prof ${ }^{a}$. Dr ${ }^{a}$. Daniela Chatelard e a Prof ${ }^{a}$. Dr ${ }^{\mathrm{a}}$. Márcia Portela de Carvalho pela participação e contribuições à versão final;

A Beatriz Lavieri, pelo acompanhamento da minha trajetória, pela leitura atenta e pelo olhar comprometido com o meu trabalho e com meu estilo;

Aos colegas do grupo de pesquisa Psicanálise, Subjetivação e Cultura, pelo trabalho ao longo destes quatro anos;

Aos alunos da disciplina Teorias Psicanalíticas II, parte do meu estágio de docência, pela possibilidade de uma transmissão e de um aprendizado instigantes e questionadores. Em especial a André Gouvêa, Suzana Gouvêa e Bruno de Paula pela 
formação do grupo de leitura e por compartilhar discussões fundamentais à construção deste trabalho;

Aos amigos queridos Renata Leite Soares e Mauro Pioli, por animarem meus dias com uma amizade sincera e um laço prazeroso de trabalho;

A Matheus Ferreira, meu parceiro na vida e nas letras, o agradecimento é especial. Por seu olhar atento, sua escuta sensível e sua leitura dedicada. Pelas discussões de textos teóricos, pelos ajustes de concordâncias verbais e, principalmente, por sempre abrir espaço em mim para a poesia e incursões literárias. Obrigada sempre!

À minha família, meus pais, meus irmãos e minha irmã, pelo continum dessa experiência de amor que dá suporte ao caminhar e afago às exigências da vida!

A Zalex Romera Suffert, pelo encontro singular comigo mesma;

Por fim, agradeço à experiência clínica que em suas duas dimensões, prática clínica e análise pessoal, fomentaram esta pesquisa. 
Talvez eu seja O sonho de mim mesma

Criatura-ninguém

Espelhismo de outra

Tão em sigilo e extrema

Tão sem medida

Densa e clandestina

Que a bem da vida A carne se fez sombra.

Talvez eu seja tu mesmo

Tua soberba e afronta.

E o retrato

De muitas inalcançáveis

Coisas mortas.

Talvez não seja. E ínfima, tangente

Aspire indefinida

Um infinito de sonhos

E de vidas.

Hilda Hilst ${ }^{1}$

\footnotetext{
${ }^{1}$ Hilda Hilst (2004, p. 82).
} 


\section{RESUMO}

A tese desenvolvida neste trabalho articula o feminino à noção de irrepresentável, a partir dos fundamentos de Sigmund Freud e de Jacques Lacan. A necessidade de articular esse tema se apresentou a partir dos impasses vivenciados na experiência clínica, principalmente dos questionamentos acerca do dispositivo analítico - a interpretação -, desembocando na questão do manejo clínico com o irrepresentável do gozo feminino. A psicanálise confere um lugar à discussão sobre o feminino e se empenha em indagar sobre a particularidade de um gozo especificamente feminino cuja principal característica é sua não inscrição nos domínios da linguagem - seu caráter irrepresentável. Na delimitação do feminino, recorremos ao ensino de Freud, à experiência com as histéricas, à teorização sobre o falo e à fundamentação da diferença sexual como estrutural e estruturante do psiquismo. Recorremos, ainda, ao ensino de Lacan na sua teorização sobre o mais além do falo que desemboca na questão do gozo feminino. Quanto ao irrepresentável, baseamos sua definição na articulação de conceitos cruciais à prática analítica: o de representação, em Freud, os de real, simbólico e imaginário, em Lacan, assim como nas noções de letra e significante e nas funções da fala e da escrita. A partir do ensino de Lacan, o feminino ganhou o estatuto de uma particularidade de gozo, pois, segundo ele, uma mulher é dividida em seu gozo. O falo, como significante que representa o sexo no inconsciente, não é suficiente para representar o feminino, pois ele só abarca a parte fálica do gozo. Há, no feminino, um gozo Outro que frui justamente em função da falta de um significante que inscreva o sexo da mulher no simbólico, no campo do Outro. É um gozo que se produz no ponto de furo do campo do Outro, onde o sujeito experimenta uma ausência de si, resultado da falta de inscrição simbólica, para viver, em uma espécie de assujeitamento, uma experiência com o irrepresentável. A leitura feita neste trabalho sobre a articulação entre o feminino e o irrepresentável na clínica psicanalítica segue a via do fazer poético e da invenção, que funcionam na cena analítica como um savoir-y-faire, um saber-fazer-ali, diante do real, do impossível e dos limites que o gozo impõe à palavra. Não é um saberfazer comum, daqueles que se constituem nos moldes de um oficio onde algo é aprendido e transmitido. O savoir-y-faire é um saber-fazer com o vazio, no sentido de se virar, o sujeito, com o gozo que insiste irrepresentável, se virar com o traço radicalmente singular registrado como marca no gozo que insiste na repetição. Seguimos, então, a indicação de que, na clínica, o trabalho com o feminino convoca uma interpretação que inclua o irrepresentável, o que nos leva, ao mesmo tempo, ao campo da escritura, aos limites da interpretação e à invenção de uma saída singular e criadora.

Palavras-Chave: Freud, Lacan, Feminino, Gozo, Irrepresentável, Interpretação, Poesia. 


\section{RÉSUMÉ}

La thèse développée dans cette étude articule le fèminin à notion de l'irreprésentable a partir des fondamentaux de Sigmund Freud e de Jacques Lacan. La nécessité d'articuler ce thème est présenté par les impasses rencontrées dans l'expérience clinique, principalement de questions sur le dispositif d'analytique - l'interprétation - par rapport à la question de la jouissance féminin irreprésentable dans la clinique psychanalytique. La psychanalyse donne un lieu de discussion sur le fèminin et s'efforce de se renseigner sur la particularité d'une jouissance spécifiquement féminine dont la principale caractéristique est sa non-inclusion complète dans les domaines de la langage. À propos du théme du fèminin nous nous référons à l'enseignement de Freud, l'expérience avec l'hystérique, des théories sur le phallus et la différence sexuelle comme structurelle du psychisme. Nous avons également fait appel à l'enseignement de Lacan dans sa réflexion sur au-delà du phallus qui conduit à la question de la jouissance féminine. Quant à l'irreprésentable, nous basons leur définition sur l'articulation des notions cruciales pour la pratique analytique: la notion de représentation dans Freud; la notion de réel, symbolique et imaginaire chez Lacan, les notions de lettre et signifiant, ainsi que les fonctions de la parole et de l'écriture. De l'enseignement de Lacan, le féminin a gagné le statut d'une particularité de jouissance, parce que, il s'agit d'une divisée - une femme est divisé en son jouissance. Le phallus, comme signifiant que représente le sexe dans l'inconscient, n'est pas suffisant pour représenter le féminin car il ne couvre qu'une partie de la jouissance, le phallique. Il y a dans la femme une jouissance Autre que frui précisément en raison de l'absence d'un signifiant qui enregistre le sexe de la femme dans la symbolique, dans le domaine de l'Autre. C'est une jouissance qui est produit au point de trou de champ de l'Autre, où le sujet éprouve une absence de lui-même en raison de l'absence d'inscription symbolique, et, dans une sorte de assujettissement, il vit une expérience avec l'irreprésentable. La lecture que nous faisons dans cette thèse sur la relation entre le fèminin et l'irreprésentable dans la clinique psychanalytique, suit le chemin de la poésie et de l'invention, dont ils fonctionnent sur la scène analytique comme un savoir-y-faire, um savoir-faire là devant le réel, l'impossible, du limite que la jouissance met à le signifiant. N'est-ce pas un savoir-faire commun, ceux qui apprennent comme un office et, par conséquent, ne peuvent pas être transmis. Le savoir-y-faire est un savoir-faire avec le vide, c'est à dire, se tournant vers la jouissance qui insiste irreprésentable, c'est-à-tourner avec le trait radicalement singulier enregistré en tant que marque dans la jouissance qui insiste sur la répétition. Nous suivons, alors, l'indication que dans le travail clinique avec le fèminin appelle une interprétation qui inclut l'irreprésentable, ce qui nous amène à la fois dans le domaine de l'écriture, les limites de l'interprétation et l'invention d'une sortie unique et créative.

Mots-clè: Freud, Lacan, Féminin, Jouissance, Irrepresentable, Interpretation, Poésie. 


\section{SUMÁRIO}

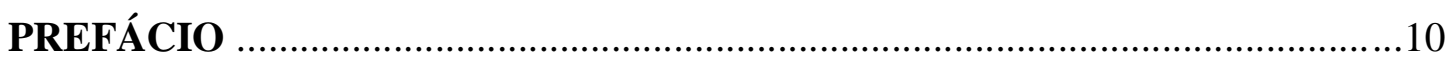

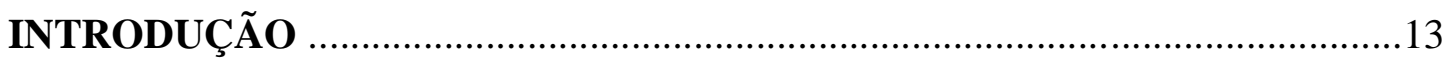

\section{CAPÍTULO 1 - Entre elas: de uma mulher à outra}

1.1 Freud e as Histéricas: uma leitura acerca do feminino ……................................24

1.2 A diferença sexual, a castração e o Édipo: referências ao percurso feminino ......29

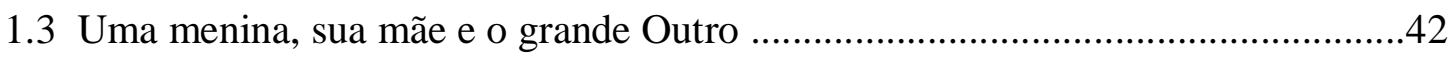

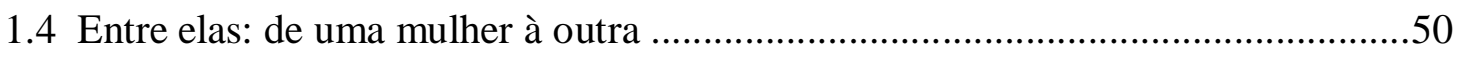

\section{CAPÍTULO 2 - O Irrepresentável: o traço real}

2.1 A Representação e o Irrepresentável .............................................................61

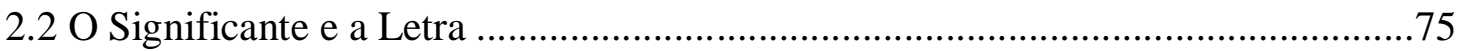

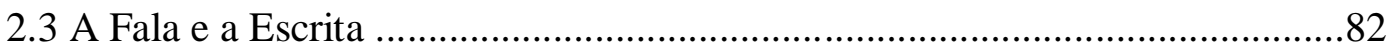

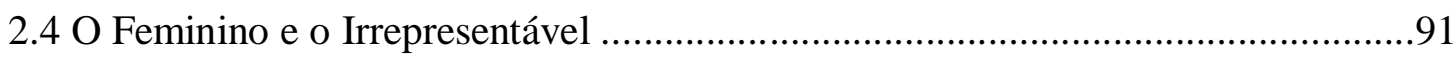

\section{CAPÍTUlO 3 - Perspectivas Clínicas}

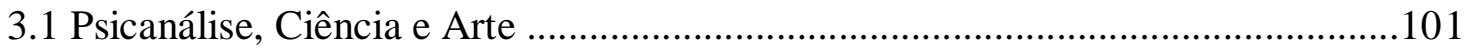

3.2 A linguagem do inconsciente e a linguagem poética ..........................................108

$3.3 \mathrm{O}$ irrepresentável entre psicanálise e poesia .........................................................114

3.4 O trabalho com o feminino e o irrepresentável na clínica psicanalítica .................124

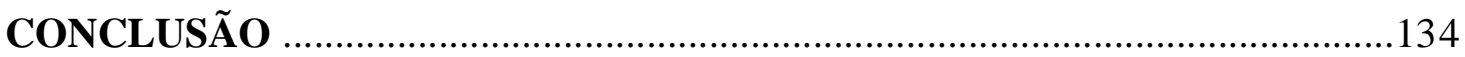

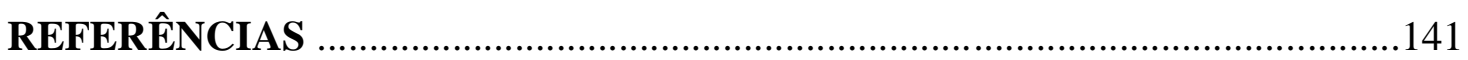




\section{PREFÁCIO}

O presente trabalho intitulado $O$ feminino e o irrepresentável é resultado da pesquisa realizada no período entre outubro de 2010 e novembro de 2014, no Programa de Pós-Graduação em Psicologia Clínica e Cultura (PPGPsiCC), do Instituto de Psicologia (IP), da Universidade de Brasília (UnB), sob a orientação da Prof ${ }^{a}$. Dr ${ }^{a}$. Terezinha de Camargo Viana e com financiamento da CAPES - Coordenação e Aperfeiçoamento de Pessoal de Nível Superior.

O objeto de estudo da pesquisa é a especificidade da inscrição do feminino no campo do inconsciente. Tal especificidade no âmbito da teoria Lacaniana, referencial teórico norteador dessa pesquisa, remete à noção de irrepresentável, na medida em que não há representação suficiente para o feminino no inconsciente. A localização do irrepresentável no cerne do feminino é o motivo pelo qual buscamos a interlocução com a Arte, mais especificamente a poesia, nos limites em que ela subverte a linguagem, afastando-se da lógica científica e buscando uma forma de articular o real.

Assim, fica definido como objetivo da pesquisa demonstrar a importância de o trabalho com o feminino na clínica psicanalítica apoiar sua metodologia de intervenção no fazer poético, a partir da hipótese de que a maneira de articular o irrepresentável, na abordagem clínica do feminino, é buscar uma intervenção que leve em conta o real em jogo, conforme será desenvolvido ao longo do texto.

A metodologia utilizada foi a da pesquisa bibliográfica, tendo como referencial teórico os estudos de Sigmund Freud a respeito da diferença sexual, da feminilidade e da arte, e de Jacques Lacan, em especial os Seminários 20, Mais ainda e 7, A ética da psicanálise, no qual ele trabalha o feminino e as relações da psicanálise com a arte, 
respectivamente, tomando como baliza a clínica psicanalítica, tanto em sua vertente de prática profissional como de experiência pessoal de análise.

Ao longo da pesquisa bibliográfica, alguns espaços de discussão foram importantes por permitir o contato com diferentes estudantes e pesquisadores e, consequentemente, diferentes opiniões a respeito do tema, que apontaram novas indicações de bibliografia, dentre eles: o grupo de pesquisa Freud, a literatura e a subjetivação contemporânea: linhas de interlocução, conduzido pela professora Terezinha de Camargo Viana; a formação do grupo de leitura com os alunos da disciplina Teorias Psicanalíticas II, decorrente da realização do estágio de docência; e a realização do Estágio de Doutorado Sanduíche no Exterior, transcorrido entre janeiro e julho de 2014, no Laboratoire de Cliniques Psychopathologiques et Interculturelle da Université de Toulouse - Jean Jaurès, França, sob a orientação do Prof. Dr. Marie-Jean Sauret e com financiamento da CAPES. A experiência de estágio trouxe um aprofundamento e a finalização deste trabalho de pesquisa, tendo em vista o referencial teórico Lacaniano presente nas pesquisas e nos estudos desenvolvidos no laboratório, bem como, o enfoque nas questões da clínica psicanalítica.

Por fim, a Banca de Qualificação, realizada em setembro de 2012, foi um momento especialmente significativo por ter situado as possibilidades e os limites do trabalho e ter permitido uma reorganização e a tomada de novas conduções para o texto. Esse momento permitiu ter uma maior clareza a respeito do lugar assumido pela poesia, para a pesquisa, e localizar a interlocução entre esta e a psicanálise, no que se refere ao feminino.

Dessa forma, o último período de pesquisa foi dedicado a amarrar os estudos sobre o feminino e sobre o irrepresentável ao fazer poético, tanto no que diz respeito ao 
jogo com a linguagem como ao ato de criação em torno do vazio onde reside o irrepresentável.

Isto posto, esperamos que o trabalho possa ser útil para consultas e estudos posteriores e agradecemos a atenção do leitor e, em especial, da banca julgadora pela oportunidade de discussão e pelas contribuições.

Paula Oliveira Sobral 


\section{INTRODUÇÃO}

A Mulher da cultura, da política, do escarro. A mãe, a mulher da vida e do trabalho. Nomear a mulher pode dizer da sua condição, do seu fardo, mas não desvenda seu enigma. Faladas nas músicas, descritas nos poemas, narradas em prosa, pintadas em telas, o lugar da mulher oscila entre adoração e questionamentos: Quem é essa mulher? A psicanálise confere um lugar à discussão sobre o enigmático universo feminino e empenha-se em indagar sobre a particularidade de um gozo que não se representa completamente pela palavra, um Outro gozo que resta sempre irrepresentável.

A tese desenvolvida neste trabalho articula $o$ feminino à noção de irrepresentável, a partir dos fundamentos de Sigmund Freud e de Jacques Lacan. A necessidade de articular esse tema apresentou-se a partir dos impasses vivenciados na experiência clínica e, principalmente, dos questionamentos acerca do dispositivo analítico: a interpretação, desembocando na questão de como manejar clinicamente o irrepresentável do gozo feminino. Essa é a questão norteadora deste trabalho. A hipótese desenvolvida é a de que a maneira de articular o irrepresentável, na abordagem clínica do feminino, é buscar uma intervenção que leve em conta o real em jogo e que ressoe no que do gozo resta irrepresentável, por isso a inspiração na função poética da linguagem e no fazer poético da criação.

No percurso de delimitação do feminino, recorremos ao ensino de Freud, sua experiência com as histéricas, a teorização sobre o falo e a fundamentação da diferença sexual como estrutural e estruturante do psiquismo. Recorremos, ainda, ao ensino de Lacan na sua teorização sobre o mais além do falo, que desemboca na questão do gozo feminino. Quanto ao irrepresentável, baseamos sua definição na articulação de conceitos cruciais à prática analítica: o conceito de representação, em Freud, de real, simbólico e 
imaginário, em Lacan, assim como as noções de letra e significante e as funções da fala e da escrita.

No curso da sua obra, Freud faz distinções acerca do homem e da mulher, bem como do masculino e do feminino. Para ele, essas instâncias não se equivalem, o primeiro par diz da diferença anatômica dos sexos e o segundo da situação psíquica que envolve essa diferença, isto é, do órgão aprisionado na dialética do desejo. Feminino e masculino são porções, traços que se inscrevem no psiquismo, ancorados na leitura/interpretação que cada sujeito faz da diferença, que é sempre sexual. As porções masculinas e femininas estão presentes, ao mesmo tempo, em um só sujeito, seja ele homem ou mulher.

Para falar da porção feminina - e, nesse trabalho propomos uma leitura do feminino na mulher - Freud o faz apoiado na lógica fálica, ou seja, situa o feminino em relação ao falo, nomeando o falo para designar o sexo do homem e a ausência do falo para o sexo da mulher. Lacan (1955-1956/2002) aborda a diferença sexual em termos de significante, afirmando tratar-se de uma dissimetria no nível simbólico. Segundo ele, a diferença está ancorada no fato de que o falo, como significante que inscreve o sexo do homem no inconsciente, confere a ele uma representatividade suficiente. Suficiente quer dizer que o gozo masculino encontra no falo sua intensidade e seu limite.

Quanto à mulher, ela é dividida em seu gozo. O falo, como significante que representa o sexo no inconsciente, não é suficiente para representar o feminino, pois ele abarca somente a parte fálica do gozo feminino. Há, no feminino, um gozo Outro que frui justamente em função da falta de um significante que inscreva o sexo da mulher no simbólico, no campo do Outro. É um gozo que se produz no ponto de furo do campo do Outro, onde o sujeito experimenta uma ausência de si, resultado da falta de inscrição 
simbólica para viver, numa espécie de assujeitamento, uma experiência com o irrepresentável.

Retomamos, então, o percurso de Freud com as histéricas. Ao ouvir seus relatos, ao tentar traduzir seus corpos paralisados, inundados de sintomas, Freud deparou-se com um enigma. Havia uma verdade que percorria o corpo de suas pacientes, uma verdade que emergia em suas falas quando apontava algo da localização da histérica diante do sexo. Um gozo onde a significação falha e a palavra não dá conta da estranheza, do imprevisível, contradição interna de sua sexualidade. O sexual estava sempre em contradição e na hiância entre uma sexualidade em excesso e uma rejeição exagerada do sexual, emergia o enigma. Freud (1933[1932]/1987) o relacionava ao desejo, um desejo sempre insatisfeito, ligado à fantasia infantil, e localizou o Édipo como momento de elaboração da castração na mulher que abrirá as portas à feminilidade.

Nesse percurso que tem início com a demanda histérica, Freud (1933[1932]/1987) localizou no feminino um enigma e desenvolveu, ao longo de sua teoria, argumentos e características do universo feminino, destacando ser sempre um universo a descobrir, formado de encontros e desencontros. Do corpo das histéricas, a neurologia pouco tinha a dizer, já que a verdade que carregava o sintoma histérico se apresentava como cifra de um desejo recalcado e de um gozo insistente. Desejo que Freud reconhece como infantil, como aquilo que está na base do psiquismo, aquilo que o sujeito recalcou em prol do laço social com a cultura e que insiste em falar. Lacan localizou nesse ponto de enigma o gozo feminino e o definiu como um gozo extremamente singular, que desfaz o universal e tende ao infinito.

No primeiro capítulo desta tese, intitulado Entre elas: de uma mulher à outra, discorremos sobre as especificidades do feminino na mulher como forma de situar o que 
nomeamos de feminino - porção psíquica que mantém uma relação estreita com o irrepresentável, lugar de acesso ao Outro gozo. Separamos então feminino e feminilidade, apostando que a feminilidade, tal como Freud (1933[1932]/1987) propõe, é uma das saídas da menina frente à castração materna, a saída em direção à "sexualidade normal", onde a menina reconhece a mãe como castrada e, conseguindo abrir mão do objeto materno, identifica-se a ela passando a desejar um filho do seu pai.

Como veremos nesse capítulo, a castração materna inscreve um enigma, tanto na menina como no menino, que se forma a partir de um resto inapreensível à tentativa das crianças de simbolizá-la. Esse resto irrepresentável está relacionado ao feminino, ao indizível, à porção real de uma experiência. A feminilidade difere-se, mas, ao mesmo tempo, relaciona-se com o feminino na medida em que se oferece como forma de dar uma cobertura simbólica a esse ponto irrepresentável.

Optamos, neste trabalho, por estudar a inscrição do feminino especificamente nas mulheres. Para tanto, iniciamos com a leitura que Freud empreende da histeria, uma leitura que leva em conta o desejo em sua relação com as marcas da inscrição do feminino. Seguimos nos baseando na leitura de Freud sobre a constituição da mulher desde a diferença anatômica dos sexos e sua posição frente ao complexo de Édipo e ao complexo de castração até as particularidades de seu universo psíquico. Discorremos sobre a relação da menina com a mãe, localizando que na relação Entre elas se interpõe um impossível, que se faz presente e se esconde ao longo da história de uma menina. O trabalho empreendido por uma mulher na relação com um ponto nunca esclarecido no desejo da mãe é árduo, mas responsável pela unicidade de cada mulher.

De uma mulher à outra Lacan localizou o feminino e foi por meio das fórmulas da sexuação que ele articulou a posição masculina e a posição feminina. O lado homem se define todo pela função fálica, seu gozo sexual está todo inscrito no plano simbólico, 
articulado na linguagem. O lado mulher se define como não-todo inscrito na lógica fálica. O não-todo é o indicativo lógico de que a relação de uma mulher com o simbólico se dá de uma maneira particular, não-toda articulada por ele, pois no simbólico, campo do Outro, campo da palavra, o falo é a única referência do sexo, o que evidencia a falta de inscrição do gozo feminino no inconsciente - seu caráter irrepresentável.

No segundo capítulo, O Irrepresentável: o traço real, procuramos delimitar a noção de irrepresentável na psicanálise. Para tanto, propomos um contraponto com o conceito de representação, uma vez que o inconsciente, tal como Freud descreveu, é constituído por representações inscritas no psiquismo na forma de significantes. Seguimos relacionando o significante ao campo da representação e à cadeia da fala; e a letra ao campo do irrepresentável e à escritura.

Lacan nomeia de significantes, servindo-se da linguística saussuriana, a forma como as palavras aparecem no inconsciente, sem referência direta ao significado e que só produzem uma significação quando associados a outros significantes na fala do sujeito. Entretanto, as representações contêm algo que nunca se entregou inteiro à simbolização, algo irrepresentável, que marca o sujeito pelo "seu traço de saudade e seu resto de silêncio" (Kehl, 1998, p. 68). Esse resto, que se inscreve como traço, é o que permite ao sujeito falar, ancorado na dimensão da falta, falta que abre uma brecha entre o dito e o não-dito, brecha que produz incompletude entre o que se fala e o que se "quer dizer", apontando para o sujeito a estranheza que a linguagem pode lhe causar, ainda (ou, por isso mesmo) que porte algo radicalmente singular a ele.

A noção de irrepresentável surgiu a partir das leituras em torno da noção de real, desenvolvida por Lacan, e se entrelaçou com o que impõe um limite à interpretação do inconsciente, em Freud. A leitura do texto $O$ irrepresentável existe?, de Maria Rita Kehl 
(1998), trouxe para este trabalho a corroboração da utilização do termo - irrepresentável -, uma vez que a autora situa o irrepresentável como ponto o central na experiência que Freud nomeou de trauma e Lacan, de real. Entre a experiência traumática, ou encontro com o real, e a inscrição inconsciente desta experiência em cada sujeito - representação -, uma parte sempre resta irrepresentável, não-toda submetida ao jogo simbólico das representações.

O trauma é um ponto central na teoria freudiana sobre o inconsciente, pois é um momento de cisão necessário à estruturação psíquica. Ele, o trauma, promove uma divisão, no sujeito, situando o consciente e o inconsciente ao instaurar a existência de uma falta que faz com que a totalidade de uma experiência seja inacessível à palavra, sendo, portanto, impossível para o sujeito significá-la por completo. No trabalho com as histéricas, Freud pôde localizar o trauma como resultante e resultado dessa tensão própria do humano que é o desencaixe entre o corpo e a linguagem. A histérica veio apontar para esse limite e evidenciar que é no corpo que se aloja a palavra que falta, pois o sintoma aponta para o irrepresentável de uma experiência.

Lacan sinaliza a importância do campo simbólico para a estruturação de um sujeito, apontando que, para todo ser humano, sua história é unificada pela lei, pelo universo simbólico, que não é o mesmo para todos (Lacan, 1953-1954/2009). Para ele, o trauma de que falamos é o encontro sempre faltoso do sujeito com a linguagem na tentativa de simbolizar o real que escapa à representação.

O trabalho clínico psicanalítico é possível por essa palavra que falta. Não que essa palavra exista de fato, mas existe de falta, e é por faltar que o sujeito coloca as demais palavras em circulação, associando-as a outras palavras, numa tentativa de falar o indizível. O indizível é um ponto que impõe um limite ao que vem sendo representado por meio das palavras associadas pelo sujeito em sua fala. É um momento de vazio. 
Vazio de angústia? Vazio propício à criação? Qual o estatuto da interpretação nesse momento? Que forma de interpretação poderia acessar, ainda que não diretamente, a esse ponto desconhecido, estranho e talvez, ao mesmo tempo, o mais familiar traço que marca a singularidade de cada sujeito? E, ainda, o que esse ponto desconhecido tem a ver com o feminino?

Lacan, apoiado na palavra que circula nas formações do inconsciente delimitadas por Freud - sonhos, atos falhos, chistes, sintomas -, destaca a noção de significante e a instância da letra no inconsciente. O sujeito é efeito de linguagem, em sua estrutura e em sua incompletude, ou seja, naquilo que é possível ser veiculado pela palavra - o significante - e naquilo que a estrutura simbólica da palavra não consegue abarcar, o real, a letra, o traço radical de um sujeito.

Ao articular o feminino ao real (irrepresentável), Lacan situou na letra o caractere responsável pelo rastro de gozo de um sujeito, um traço que faz borda entre o saber e o gozo e que vem marcar o caráter de escritura presente no inconsciente. A letra é o escrito de gozo no corpo que faz resistência ao saber, se apresentando como furo no simbólico. Quando se trata do feminino, o fato de não haver um significante que o defina torna necessário que na experiência analítica se faça engendrar a leitura da letra, a escrita na palavra, aquilo que só se apresenta na forma de um apagamento, de uma fissura na linguagem, de um buraco no sentido e que insiste sempre e mais, ainda.

A proposta do terceiro capítulo, Perspectivas clínicas, é relacionar o questionamento trazido pela tese à interpretação, instrumento da psicanálise, entendida de formas tão diversas na clínica e na cultura. Na experiência com as histéricas, Freud passa da hipnose à escuta, apontando a palavra como veículo dessa verdade denunciada de forma cifrada no sintoma histérico, evidenciando a relação particularmente humana entre corpo e linguagem. A forma de intervenção clínica nos sintomas, Freud nomeou 
de interpretação por eleger a palavra como possibilidade de acesso ao saber inconsciente. Esse é um saber não-sabido pelo sujeito e que, por ser o inconsciente estruturado como uma linguagem, se articula numa cadeia de linguagem no ato de fala.

Para Freud, interpretar é um ato simbólico que, por sua estrutura de linguagem, convoca um jogo de representações que se associam a outras representações fazendo-se um dispositivo a serviço do inconsciente, pois as significações são produzidas por meio de associações, combinações ou oposições entre as palavras. Ao trabalhar com a noção de representação, Freud chama atenção para a maneira com as experiências se inscrevem no psiquismo e como estas inscrições estruturam a subjetividade.

No centro da rede de representações que estruturam o psiquismo, se impõe um furo, espaço vazio de representação, morada do irrepresentável. Lá, a interpretação encontra um limite, pois o que se desdobra não é da ordem de uma significação que pede deciframento e sim de uma significância, daquilo que se produz devido ao vazio de significação - uma cifra de gozo.

A discussão feita nos capítulos anteriores ganha articulação no último, onde o feminino e o irrepresentável recebem uma leitura clínica. Dizer que este trabalho propõe uma leitura acerca do feminino nos permite dizer, ao mesmo tempo, que ela é não-toda, uma vez que tantas outras possibilidades se fazem notórias, pois o tema do feminino é visitado pelos diversos campos do conhecimento que produzem incessantemente um saber sobre o lugar, o dizer e os desejos femininos. A ele atribuem-se teorias, respostas, explicações e, a cada produção, abrem-se brechas e, com elas, a possibilidade de novos estudos e de novas buscas.

A leitura feita neste trabalho sobre a articulação entre o feminino e o irrepresentável na clínica psicanalítica segue a via do fazer poético e da invenção, que funcionam na cena analítica como um savoir-y-faire, um saber-fazer-ali, diante do real, 
do impossível, dos limites que o gozo impõe à palavra. Não é um saber-fazer comum, daqueles que se constituem nos moldes de um oficio onde algo é aprendido e transmitido. O savoir-y-faire é um saber-fazer com o vazio, no sentido de se virar com o gozo que insiste irrepresentável, se virar com o traço radicalmente singular registrado como marca no gozo que insiste na repetição. "Repetir repetir - até ficar diferente. Repetir é um dom do estilo" é o que entoa o verso de Manoel de Barros (2007, p. 11).

Seguimos, então, a indicação de que, na clínica, o trabalho com o feminino convoca uma interpretação que inclua o irrepresentável, o que nos leva, ao mesmo tempo, ao campo da escritura, aos limites da interpretação e à invenção de uma saída singular e criadora.

A intenção nesse capítulo é traçar uma via de aproximação entre a psicanálise e a arte, enfatizando o caráter não objetivável da experiência analítica, uma experiência que comporta no seio de si mesma uma verdade que não pode ser dita por completo porque o saber que a constitui é um saber inconsciente, não-sabido pelo sujeito, e sua verdade é definida pela fala na relação com o gozo, por isso imprevisível e singular.

Localizar a psicanálise como um campo mais próximo da arte do que da ciência positivista é uma indicação que encontramos nos textos nos quais Freud discorre sobre a relação da psicanálise com a literatura e que será também enfatizada por Lacan no percurso de sua obra. Seguimos algumas indicações da convocação feita, por Freud e por Lacan, à poesia quando aparece um ponto de limite na interpretação analítica: a indicação de Freud (1933[1932]/1987) de que no feminino algo devia ser perguntado aos poetas e a indicação de Lacan (1976-1977) de que só a poesia permite a interpretação em psicanálise.

Recorrer à poesia é se deparar com o poder que a palavra tem de provocar um furo no saber, apontando que a palavra não deve ser tomada com fixidez, ao contrário, 
seu poder deve residir no fato de que ela comporta o irrepresentável em sua estrutura e é aí que reside a força da palavra, sua função criadora/criativa. 


\section{CAPÍTULO 1}

\section{Entre elas: de uma mulher à outra}

Aflição de ser eu e não ser outra.

Aflição de não ser, amor, aquela Que muitas filhas te deu, casou donzela

E à noite se prepara e se advinha

Objeto de amor atenta e bela. Aflição de não ser a grande ilha Que te retém e não te desespera. (A noite como fera se avizinha).

Aflição de ser água em meio a terra E ter a face conturbada e móvel.

E a um só tempo múltipla e imóvel

Não saber se ausenta ou se te espera.

Aflição de amar se te comove. E sendo água, amor, querer ser terra.

Hilda Hilst ${ }^{2}$

\footnotetext{
${ }^{2}$ Hilda Hilst (1999, p. 40).
} 


\subsection{Freud e as Histéricas: uma leitura acerca do feminino}

O termo histeria tem origem nos primórdios da medicina e resulta do preconceito que vincula as neuroses às doenças do aparelho sexual feminino. Desconsiderada pela clínica médica, que nomeava os fenômenos histéricos de simulação e exagero, foi somente no século XIX, com Charcot e os estudos na escola do Salpêtrière, que a histeria ganhou uma melhor compreensão e uma abordagem adequada (Freud, 1888/1987). Em um momento em que a medicina não dava crédito às enigmáticas manifestações das doenças nervosas, Charcot delimitou a histeria como um quadro clínico com leis e regularidades próprias, restaurando sua dignidade frente à sociedade e à comunidade médica. Freud segue a concepção de Charcot de que a histeria é um quadro clínico circunscrito e delimitado e se detém no estudo dessa neurose.

Foi no percurso com as histéricas, ao ouvir seus relatos e tentar traduzir os corpos paralisados e inundados de sintomas, que Freud se deparou com o inconsciente, uma instância que se encontra em todo sujeito, saindo, assim, da visão puramente patológica da histeria e aproximando-a da "normalidade", o que promoveu uma passagem no estudo de Freud da neurose histérica, enquanto doença nervosa, à arquitetura da histeria (Quinet, 2005). Por sua vez, deparou-se também com algo específico da sexualidade feminina, uma marca que ganha ancoragem no vazio de representação do órgão no corpo da mulher. Ao fazer falar as histéricas, Freud se encontrou com uma verdade que emergia em suas falas, que percorria seus corpos quando apontava algo da localização da histérica diante do sexo.

Freud indaga a natureza inconsciente do conteúdo desses relatos e, a princípio, percebe tratar-se de uma experiência na vida sexual infantil. Segue distinguindo, na histérica, algo diferente do que ocorria na neurose obsessiva, e identifica um traço 
feminino, associado à passividade, na estrutura histérica, e masculino, associado à atividade, na estrutura obsessiva. Essa é uma delimitação inaugural, a partir da qual virão desdobramentos, avanços e formulações. Com Freud, as histéricas são tomadas uma a uma e a psicanálise inaugura uma nova leitura acerca do feminino, levando em conta o enigma que bordeja sua particularidade.

No encontro com a histeria, Freud (1893-1895/1987) começa por tentar diferenciar as paralisias motoras orgânicas das paralisias histéricas. Naquele momento, atribuía-se às histéricas a capacidade de simular as mais diferentes doenças orgânicas e, por este motivo, Freud relata uma série de características distintas entre tais paralisias.

Freud explica haver, nas paralisias orgânicas, uma interligação e uma hierarquia entre órgãos, músculos, membros, fibras e terminações que são seguidas no momento em que aquelas acontecem. Assim, quando uma determinada parte do corpo paralisa, há partes conexas que igualmente paralisam, pois o que é levado em conta é a localização e a extensão da lesão ocorrida. Já na histeria, “os sintomas da paralisia orgânica aparecem como que fracionados" (Freud, 1893-1895/1987, p. 233), de tal maneira que é possível dissociar, com facilidade, um membro de seu segmento, ou isolar algumas funções sem que outras, ligadas a ela, sejam prejudicadas. Há, portanto, uma delimitação precisa do órgão ou membro paralisado.

Freud (1893-1895/1987) enfatiza que a natureza dessa lesão independe da anatomia do sistema nervoso, pois a histeria se comporta como se a anatomia não existisse ou como se não houvesse conhecimento desta, "ela toma os órgãos pelo sentido comum, popular, dos nomes que eles têm: a perna é a perna até sua inserção no quadril, o braço é o membro superior tal como aparece visível sob a roupa” (p. 240).

Do ponto de vista psíquico, Freud relata ocorrer uma falha associativa entre o membro ou o órgão em si (braço, perna, face, etc.) e a concepção correspondente a ele. 
Acontece, então, uma fixação entre uma ideia associada ao braço, a partir de algum evento traumático, e o braço enquanto membro. Essa fixação comporta uma carga afetiva e isso impede que novas associações sejam feitas, permanecendo, o braço, paralisado. "Se numa associação, a concepção de braço está envolvida com uma grande quantidade de afeto, essa concepção será inacessível ao livre jogo de outras associações" (Freud, 1893-1895/1987, p. 243).

$\mathrm{Na}$ histeria, o paciente afirma nada saber sobre a causa do seu sofrimento, ele se encontra em um "estado de ânimo em que é possível a uma lembrança expressar seu afeto através de fenômenos somáticos, sem que o grupo dos outros processos mentais, o eu, tome conhecimento disso ou possa interferir para evitá-lo" (Freud, 1893-1895/1987, p. 28). Os fenômenos histéricos, portanto, se produzem a partir de uma ligação entre o inconsciente e o somático à revelia do eu. Há uma divisão que impede essa tomada de consciência que, mais tarde, Freud nomeará de recalque. A partir de um evento traumático experimentado pelo sujeito, algo é "esquecido", recalcado e armazenado no inconsciente, o que, a posteriori, será material constituinte das fantasias.

Logo surgiria o problema de saber como é que um paciente histérico é dominado por um afeto em relação a cuja causa afirma nada saber. Se nos ativermos a nossa conclusão de que deve existir um processo psíquico correspondente, e se, ainda assim, acreditarmos no paciente quando ele o nega; se reunirmos as múltiplas indicações de que o paciente se comporta como se de fato soubesse disso; e se penetrarmos na história da vida do paciente e descobrirmos alguma ocasião, algum trauma, que pudesse evocar de maneira adequada exatamente aquelas expressões do sentimento - então tudo apontaria para uma solução (Freud, 1893-1895/1987, p. 28). 
Freud acreditava que a maneira de fazer desaparecer os sintomas histéricos seria rememorar algo ligado ao evento traumático e relacioná-lo ao afeto. Assim, o membro ou órgão paralisado seria liberado, podendo entrar em uma nova cadeia associativa. Portanto, as paralisias histéricas pareciam estar relacionadas com a representação imaginária que se faz do órgão, e não com a anatomia - o órgão como símbolo concreto do que não consegue ser veiculado pela palavra. Os estudos sobre a histeria, os procedimentos clínicos e as técnicas desenvolvidas a partir desse estudo conduziram à fundação da psicanálise, como o campo da fala por excelência.

Freud inicia seus atendimentos baseando-se na 'cura pela fala' associada à hipnose, uma forma de abordagem para a histeria fundada a partir do caso clássico tratado por Breuer: o da Sta. Anna O., uma jovem de 21 anos que manifestara uma série de sintomas que pareciam ter relação com a doença de seu pai. Durante os atendimentos, narrava o que lhe acontecia diariamente, seu sofrimento e suas "alucinações", e, por vezes, ao detalhar o aparecimento de um sintoma, esse desaparecia. Ao falar, sentia um alívio, apontando a conexão entre a palavra e o corpo.

Esse atendimento ganha extrema relevância para Freud e marca a importância da fala no desvendamento dos sintomas histéricos e na fundação da psicanálise. O tratamento da histeria por meio da fala evidenciou a existência de um saber inacessível à consciência, apontando para a dimensão inconsciente.

A própria paciente de Breuer, Anna O., demonstrou e superou o primeiro desses obstáculos — a amnésia característica dos pacientes histéricos. Quando a existência dessa amnésia foi trazida à luz, seguiu-se de imediato a compreensão de que a mente manifesta do paciente não é a mente em sua totalidade, havendo por trás uma mente inconsciente (Freud, 1893-1895/1987, p. 23). 
No difícil exercício de ouvir o que a paciente tinha a dizer, sem interrompê-la, permitindo e apostando no fluxo da fala das histéricas, Freud chega à técnica da associação livre e ao inconsciente. Ao contrário do que pensava inicialmente, não ocorria uma ligação direta entre a lembrança da experiência e uma descarga afetiva, provocando a remissão dos sintomas, ao referir-se às histéricas. Diferente disso, a lembrança vinha primeiro, era a causadora. Os sintomas histéricos apareciam, então, como símbolos de uma recordação, despertada por algum acontecimento e convertida em um sintoma no corpo (Quinet, 2005). Segundo Quinet, os sintomas têm uma significação que é sexual e, por isso, expressam a realização de um desejo. Esse desejo traz uma carga traumática e, por isso, se aloja no inconsciente, em forma de fantasias.

Para Freud, ocorria uma ruptura e o $e u$ não reconhecia a experiência como própria a ele e, sendo incompatível, deveria ser rechaçada. "Quando criança, o sujeito teve uma experiência sexual cuja carga de afeto foi insuportável para o sujeito e lhe é inconciliável com a consciência" (Quinet, 2005, p.103). Assim, nascia a forte ligação das histéricas com o inconsciente, com um saber desconhecido que aparecia no corpo manifestado por meio de paralisias e anestesias. A inacessibilidade do saber inconsciente é resultado de uma operação que marca o sujeito: a castração. Operação vivida imaginariamente, apoiada no falo, o símbolo da falta inaugurada pela dialética ausência e presença, que bordejará a diferença anatômica dos sexos, a distinção de masculino e feminino e a passagem pelo complexo de Édipo.

Para Lacan (1964/1998), o interesse e a sagacidade de Freud em relação às histéricas fundam a psicanálise na medida em que a histeria denuncia a relação do sujeito com o seu desejo - um desejo sempre insatisfeito - e com o gozo - aquilo que insiste nas repetições. O sintoma histérico é uma resposta sintomática, uma forma nãotoda de dizer algo sobre isso que reside no inconsciente e que o sujeito demonstra 
desconhecer. "O caminho do inconsciente propriamente freudiano, foram as histéricas que o ensinaram a Freud" (Lacan, 1964/1998, p. 20).

\subsection{A diferença sexual, a castração e o Édipo: referências ao percurso feminino}

As constatações possíveis de se fazer pela observação do exterior, bem como do interior do corpo humano, permanecem para nós sem valor, pois o que se trata de apreender não é uma diferença entre órgãos ou cromossomos que determinam nossa configuração, mas uma diferença de sexos - esse termo designando aqui, para além da materialidade da carne, o órgão enquanto aprisionado na dialética do desejo, e dessa forma "interpretado" pelo significante (André, 1994, p. 11).

Durante toda a sua obra, Freud faz distinções acerca do homem e da mulher, bem como do masculino e do feminino. Para ele, essas instâncias não se equivalem, o primeiro par diz da diferença anatômica dos sexos e o segundo da situação psíquica que envolve essa diferença, ou seja, diz do órgão aprisionado na dialética do desejo. “Aquilo que constitui o masculino ou o feminino é uma característica desconhecida que foge do alcance da anatomia" (Freud, 1933[1932] /1987, p. 115).

A constituição psíquica, para Freud, desenvolve-se apoiada na diferença sexual, em uma relação com as experiências sexuais da criança na infância e, principalmente, com a subordinação dessas aos desejos inconscientes. Nos Três ensaios sobre a teoria da sexualidade, Freud (1905/1987) começa a delinear as diferenças existentes na constituição psíquica, quanto à sexualidade, pelo par atividade e passividade, e afirma ser na fase fálica que a polaridade sexual coincide com masculino e feminino. No texto A organização genital infantil, Freud (1923/1987) privilegia o conceito de falo na construção da teoria da sexualidade, afirmando que, para ambos os sexos, o que está presente "não é uma primazia dos órgãos genitais, mas uma primazia do falo" (p. 180). 
Lacan, no retorno que faz à obra freudiana, retoma a noção de falo e a importância deste no que diz respeito à diferenciação sexual. Para enfatizar a pontuação de Freud de a realidade do sexo não ser a realidade anatômica e que, portanto, a relação estabelecida pelo sujeito com o falo desconsidera, a priori, tal realidade, Lacan recorre à fábula de Dafne e Cloé, escrita por Longo, um poeta grego, e que narra a história de duas crianças que haviam sido deixadas pelos pais apenas com etiquetas que marcavam seus nomes. Essas crianças, o menino Dafne e a menina Cloé, foram criadas por pastores, na vida do campo, afastadas da cidade. Surge entre eles um forte sentimento ao qual Eros nomeou para eles de amor e, ao nomear, conferiu um lugar, no campo simbólico da palavra, ao que sentiam Dafne e Cloé. Entretanto, eles continuavam sem saber o que fazer com o amor, olhavam os animais na relva, imitavam seus movimentos deitando-se um ao lado do outro, mas nada sabiam sobre o que fazer com aquilo que percorria seus corpos. Então, uma mulher da cidade mostra a Dafine o que fazer com a diferença sexual, no nível do corpo, enquanto ato sexual, deitando-se com ele.

Lacan faz referência a essa obra literária, no Seminário 11 e no texto $A$ Significação do Falo, para tratar da decalagem entre o nível anatômico e a inscrição da diferença sexual no psiquismo, no que se refere ao ser falante. É na linguagem que, para Lacan, está ancorado o corpo sexuado do humano na diferença que se impõe em relação ao animal no que tange ao sexual. Isso ocorre tendo em vista que a atividade sexual no humano está submetida às leis da linguagem e que, portanto, essa sexuação, que situa o masculino e o feminino, não se limita ao nível do corpo - como o instinto animal. Ela passa, necessariamente, pelo significante e é apreendida do campo do Outro e aprendida com o outro.

Lacan traz da linguística saussuriana o conceito de significante e faz um uso particular dele. Ele o utiliza baseando-se no signo linguístico, de Saussure, que faz da 
formação da palavra - o signo - o resultado da união entre significado e significante. Entretanto, para falar da linguagem do inconsciente, Lacan confere primazia ao significante, colocando-o numa posição de comando em relação ao significado. Ele utiliza o conceito de significante como uma maneira de retomar a letra de Freud no ponto em que ele acredita terem havido ambiguidades de interpretação quanto ao legado freudiano. Assim, o que Lacan (1958/1998) enfatiza como necessário à leitura do ensinamento de Freud é "a noção de significante, como oposta à de significado" (p. 695) quando se trata do fenômeno analítico, uma vez que no inconsciente a inscrição se dá na forma de significantes e os significados se farão por meio das associações entre os significantes na cadeia de linguagem do sujeito.

É a descoberta de Freud que confere à oposição entre significante e significado o alcance efetivo em que convém entendê-la, ou seja, que o significante tem função ativa na determinação dos efeitos em que o significável aparece como sofrendo sua marca, tornando-se, através dessa paixão, significado (Lacan, 1958/1998, p. 695).

Essa relação com o significante, onde Lacan marca a genialidade de Freud, faz aparecer "uma nova dimensão da condição humana, na medida em que não somente o homem fala, mas em que, no homem e através do homem, isso fala" (Lacan, 1958/1998, p. 695). Nessa outra dimensão que é o inconsciente se encontra uma estrutura de linguagem, que não é a linguagem como fenômeno social, mas a linguagem que rege o que Freud nomeou de a outra cena (eine andere Schauplatz).

Esta é a descoberta freudiana no tocante ao inconsciente, a outra cena que dá origem à realidade psíquica e que formaliza imperar no psiquismo a maneira como uma experiência é representada na mente, ou seja, como ela se inscreveu no inconsciente, evidenciando a passagem da teoria da sedução para a teoria da realidade psíquica, sendo 
esta a que interessa à psicanálise como campo do sujeito. Um sujeito que, diante da impossibilidade de elaborar a experiência traumática relativa ao complexo de castração de forma completa, o faz de forma complexa, sofrendo uma divisão psíquica e fazendo precipitar um eu como medida defensiva ao sujeito do inconsciente.

Em A Interpretação dos Sonhos, Freud (1900/1987) formaliza a maneira como as experiências são inscritas no inconsciente, sem referência direta (e, por vezes, nenhuma) com os fatos acontecidos na vida do sujeito, e situa ali, no relato do sonho pelo sonhador, a cadeia de significante como correlata à cadeia do desejo e, Lacan acrescenta, do gozo. Há uma distorção, comandada pela defesa do sujeito, na maneira como esse desejo e esse gozo são veiculados em sua vida cotidiana, restando às manifestações do inconsciente - os sonhos, os sintomas, os chistes, os atos falhos -, a responsabilidade pela aparição do desejo e do gozo. As formações do inconsciente são manifestações de um desejo recalcado que retorna à revelia do sujeito para marcar a força da realidade psíquica frente à vivenciada, insistindo repetidamente como presença de gozo.

No que tange à realidade psíquica regida pelo inconsciente, Lacan (1964/1998) situa a relação do homem com o significante e enfatiza que, ao fazer isso, não está, de maneira nenhuma, negligenciando o dinamismo sexual, proposto por Freud, na essência do sujeito do inconsciente. Ao contrário, ao privilegiar a estrutura para falar da constituição do sujeito, Lacan marca um diferencial no humano no que tangue ao sexual, justamente por constituir-se como um ser de linguagem, ou seja, por padecer do significante.

O fator distintivo, portanto, da relação do ser falante com o sexo é o significante, não a anatomia, e esse significante, que instala no sujeito uma posição inconsciente, pela qual o sujeito poderá “identificar-se com o tipo ideal de seu sexo" (Lacan, 
1958/1998, p. 692), é o falo: o significante que faz girar as significações em torno do sexual e, justamente por não ter como correspondente um único significado que o encerre ou limite, institui uma cifra no questionamento do que é o ser macho e o ser fêmea.

Não se trata, portanto, da presença ou ausência na dissimetria genital, mas de tornar precisa a inexistência de uma correspondência unívoca entre significante e significado, no que diz respeito ao sexo. O manejo dos sintomas histéricos, por Freud, vem enfatizar e delimitar tal inexistência, enfatizando a não correspondência entre o sintoma, conforme aparecia no corpo das histéricas, e sua significação na ciência médica. Foi preciso buscar além do significado anatômico, no campo da fala e da linguagem, ou seja, na trama das associações significantes trazidas pelas histéricas, para encontrar um efeito de significação único e singular, pois "nada na anatomia nervosa recobre, seja o que for, do que é produzido nos sintomas histéricos. É sempre de uma anatomia imaginária que se trata” (Lacan, 1955-1956/2002, p. 204).

A primazia do falo, assim enunciada por Freud, evidencia a primazia do significante frente ao significado, uma vez que a significação a ser engendrada por cada sujeito na associação entre o falo e a sexuação dependerá do deslizamento de significantes em seu inconsciente, da maneira como eles se condensam e se deslocam, produzindo, por seu movimento, um efeito de significado.

O falo é, então, tomado como representante do sexo no inconsciente, onde impera a função fálica, ativa da pulsão, sem distinção inicial para meninos e meninas. Por ser sempre parcial em sua essência, a pulsão não representa a totalidade da tendência sexual, ela orienta o que vigora no psiquismo como representante das consequências da sexualidade, isto é, a força de atividade em relação à passividade. Daí a dominância do falo, enquanto atividade fálica, em ambos os sexos. Será somente no 
Édipo que uma diferenciação quanto ao dinamismo sexual se estabelece e as funções passam a ter algum esclarecimento, imprimindo uma força simbólica ao que será experimentado como complexo de castração pelos meninos e pelas meninas.

Assim, Lacan (1964/1998) afirma situar-se nessa dimensão o sujeito no que é esclarecido pela experiência analítica: "que as vias do que se deve fazer como homem ou como mulher são inteiramente abandonadas ao drama, ao roteiro, que se coloca no campo do Outro - o que é propriamente o Édipo" (p. 194).

Lacan (1964/1998) apresenta, na cena da dinâmica sexual, no tocante à estruturação psíquica, um elemento novo: o Outro, um campo a partir do qual o sujeito irá se presentificar e com o qual o sujeito seguirá numa relação dialética. Primeiramente, ao nascer, o bebê humano, como ser de linguagem, provido de um corpo, não sabe de forma inata o que fazer com isso, diferentemente do bebê animal. Não dá os primeiros passos, nem sai em busca de alimentos sem que haja um Outro que o oriente, pois “o imaginário do sujeito falante, opostamente ao do animal — pleno, sem brechas - , apresenta uma falta originária, uma hiância real que virá precisamente a ser preenchida pelo simbólico" (Jorge, 2008, p. 95).

Assim, o lugar do Outro, enquanto campo simbólico, é assumido para o bebê por um outro no qual irá alienar-se, buscando nele apreender significantes que possam conferir-lhe um lugar e, assim, estruturar-se. Por que esse outro é Outro? Lacan (1964/1998) define, em seu ensino, o grande Outro como "o lugar em que se situa a cadeia do significante que comanda tudo que vai poder presentificar-se do sujeito" (p. 194) e afirma ser na relação de oposição do sujeito e do Outro que ocorre o surgimento do inconsciente.

O Outro é o lugar da nomeação, da inscrição simbólica, na qual se localiza a cadeia significante. Portanto, é o lugar da fundação da subjetividade. Jorge (2008), ao 
tratar da noção de Outro, delimitada por Lacan, o situa como o campo dos significantes, na medida em que este campo marca o caráter incompleto da linguagem, não podendo ela mesma dizer, expressar, tudo, tampouco encerrar-se numa única combinatória. $\mathrm{O}$ significante se movimenta a todo instante no campo do Outro, por meio de combinações infinitas, havendo sempre a possibilidade de introduzir, por um ato criativo, um novo significante. Pois "o lugar do significante é nomeado por Lacan de Outro porque ele jamais é o mesmo, ele é sempre diverso de si mesmo, ele nunca apresenta uma identidade definitiva: ele é pura alteridade" (Jorge, 2008, p. 92).

Inicialmente, esse campo - o campo do Outro - é, para o bebê, ocupado pela figura materna, de onde virá toda a enxurrada de significantes que irão significar seus movimentos, seus choros e suspiros. Lacan (1957-1958/1999) assinala que "a primeira relação de realidade desenha-se entre a mãe e o filho, e é aí que a criança experimenta as primeiras realidades de seu contato com o meio vivo" (p. 186).

Portanto, nesse momento o Outro é essencial, primordial, e se encarna no semelhante - a mãe ou quem se ocupe dessa função -, uma vez que dele depende o bebê, sendo aí, na imensidão materna, que recebe o contorno necessário ao primeiro momento de formação, seja ainda no ventre ou quando de sua chegada à civilização. $O$ bebê está no terreno das necessidades e recorre à mãe desse lugar, ao que ela responde dando-lhe significações, cuidados corporais, alimento, isto é, saciando suas necessidades. Ela surge como uma instância que sabe sobre o bebê e que o investe libidinalmente, ocupando, nessa posição, um lugar imenso para o filho.

É o que torna o sujeito, nos dois sexos, tão dependente de um Outro que lhe diria quem ele é. O Outro, para Lacan, não é só o lugar dos significantes, mas o lugar de onde o sujeito busca uma resposta para sua existência (Zalcberg, 2003, p. 69). 
Nessa relação, a criança revela depender da mãe, do desejo da mãe, da primeira simbolização da mãe e nada mais, pois daí vêm os significantes que marcarão o sujeito, inscrevendo, em seu corpo biológico, um corpo pulsional. O desejo materno opera, assim, como desejo do Outro. Nesse momento, o falo aparece, para a criança, ligado à mãe, primeiramente como algo que possui e, posteriormente, como algo que ela deseja. Para ela, o desejo da mãe é desejo de falo, oferecendo-se como tal. "Se a mulher encontra na criança uma satisfação, é, muito precisamente, na medida em que encontra nesta algo que atenua, mais ou menos bem, sua necessidade de falo, algo que a satura" (Lacan, 1957-1958/1999, p. 71).

Lacan aponta para o fato de que inicialmente, em ambos os sexos, a mãe é considerada como provida de falo e de que a significação da castração só adquire seu alcance para o sujeito "a partir da sua descoberta como castração da mãe" (p. 693). Pois a mãe, na posição de grande Outro, ocupa o lugar daquele que tudo sabe sobre seu filho, seja ele menino ou menina. Ela é grande e, ao mesmo tempo, fascinante e ameaçadora. É preciso, então, que lhe coloque uma barra, interditando a ocupação desse lugar, retirando-lhe um pouco de seu poder. É a incidência da metáfora paterna na relação entre a mãe e a criança que tem a função de operar esse corte, separando mãe e bebê como dois territórios distintos e restituindo ao grande Outro seu lugar de depósito e de investimento para a criança no seu trajeto em constituir-se como sujeito desejante, pois “o Outro não poderia possuir uma alteridade para além de sua própria, ele já é a alteridade, ele já é Outro continuamente: nada vem lhe garantir qualquer limite definido" (Jorge, 2008, p. 92).

"De que se trata a metáfora paterna? Há, propriamente, no que foi reconstituído por uma simbolização primordial entre a criança e a mãe, a colocação substitutiva do pai como símbolo, ou significante, no lugar da mãe” (Lacan, 1957-1958/1999, p. 186). 
É nesse ponto, chamado por Lacan de axial, que está situado a essência do complexo de Édipo. O pai entra em cena para operar uma metaforização que consiste em substituir o Desejo-da-Mãe, instância imaginária, pelo Nome-do-Pai e, com isso, inserir a criança no plano simbólico. Assim, o pai instaura a colocação do significante como um recurso para a criança no lugar do corpo da mãe e isso possibilita que a criança não sucumba diante da ausência desse corpo. É da mãe como símbolo que a criança precisa e é isto o que a lei do pai vem inserir entre a mãe e a criança: uma relação simbólica.

A incidência da função paterna - Nome-do-Pai - produz uma interrogação a respeito do Desejo-da-Mãe e, consequentemente, interroga sobre a equivalência entre a criança e o falo, apontando, para a mãe e para criança, que o desejo opera metonimicamente, deslocando-se sempre de um objeto a outro, e que sua força reside nisso. Essa operação produz um corte, barrando o todo imaginário que a mãe é para a criança. Tal corte permitirá que a mãe caia do lugar de grande Outro, assumindo o lugar de um sujeito castrado, a quem também falta algo e que, justamente por faltar, ela, em algum momento, tomou a criança por falo. É função do pai operar essa intervenção, introduzindo uma interdição na relação entre a mãe e a criança.

Assim, a criança identifica o pai como portador do falo enquanto significante que dará a ela a condição de sujeito ativo em seu desejo. Com a entrada do pai, a criança desvincula sua dependência do desejo materno da vivência real dessa dependência, para vinculá-la a uma questão subjetiva. Afinal, o que o sujeito deseja? "Não se trata da simples apetência das atenções, do contato ou da presença da mãe, mas da apetência de seu desejo. A partir dessa primeira simbolização em que se afirma o desejo da criança esboçam-se todas as complicações posteriores da simbolização, na medida em que seu desejo é o desejo do desejo da mãe” (Lacan, 1957-1958/1999, p. 188). 
No texto, Diretrizes para um congresso sobre a sexualidade feminina, Lacan (1960/1998) enfatiza o cuidado em não tomar a mãe e o pai pelas pessoas que são em suas falhas e acertos reais, na relação cotidiana com a criança. Mãe e Pai, na dinâmica do complexo de castração, são funções simbólicas, isto é, operadores na estruturação da subjetividade de cada criança. Operam por meio da lei do significante. Esta realiza, no ser humano, uma decalagem entre a linguagem e o biológico, pela qual o sujeito poderá se constituir como um efeito do significante. Essa operação evidencia o caráter fundamental do Outro para a constituição do sujeito, uma vez que "o sujeito depende do significante e de que o significante está primeiro no campo do Outro" (Lacan, 1964/1998, p. 194).

Após a incidência do Nome-do-Pai, em sua função significante de falo, um corte se apresenta e promove uma divisão no próprio sujeito, que não pode mais responder a partir de uma relação direta com a necessidade, uma vez que já foi marcado pelo germe do desejo. A dimensão do desejo abre-se, evidenciando para a criança que a mãe, enquanto sujeito desejante, “deseja em termos objetivos como ser que vive no mundo do símbolo, num mundo em que o símbolo está presente, num mundo falante" (Lacan, 1957-1958/1999, p.188). Essa simbolização primordial abre, portanto, para a criança, a dimensão do que a mãe pode desejar de diferente e é assim que o desejo, sempre de Outra coisa, faz sua entrada.

Lacan (1964/1998) marca, assim, ser a questão introduzida pela abordagem de Freud relativa a uma falta estrutural como uma falta-a-ser, pois aquilo que o sujeito vive a buscar e a desejar, e que coloca em movimento a dinâmica sexual, não é a busca, no outro, de que este seja a metade sexual como aquilo que iria complementar-lhe. A procura empreendida pelo sujeito, e que vai movimentar a cadeia do desejo, bem como a do gozo, não é “do complemento sexual, mas da parte para sempre perdida dele 
mesmo, que é constituída pelo fato de ele ser apenas um vivo sexuado e não mais ser imortal" (p. 195).

É a inscrição simbólica da questão - ter ou não ter o falo? - que, em todo caso, refere-se a uma falta, uma perda que parcializa o campo imaginário do sujeito, no qual, miticamente, ele acreditou que era um ser completo, que confere dinâmica ao que é sexual e o faz dirigir-se ao outro nos laços amorosos. Afinal, a questão fálica vem introduzir que é a partir da falta "que o campo do desejo precipita seus novos objetos" (p. 739) e faz entrar na cena a função metonímica do desejo, qual seja, ser sempre desejo de Outra coisa.

Lacan (1955-1956/2002) assinala que Freud situou no Édipo o momento em que a sexuação ganha uma representação, uma inscrição simbólica no psiquismo, enquanto porções femininas e masculinas, enfatizando que estas porções são, portanto, decorrentes do percurso de cada sujeito em suas identificações, das marcações significantes feitas por aqueles que lhe destinaram os primeiros cuidados, os primeiros afetos ou por um outro que operou a função de Outro primordial.

No texto A sexualidade feminina, Freud (1931/1987) explica que, no complexo de Édipo, a criança encontra-se ligada afetivamente ao genitor do sexo oposto e que a relação com o genitor do mesmo sexo torna-se hostil. Afirma, ainda, que no menino isso se faz evidente, uma vez que a mãe, sendo seu primeiro objeto de amor, continua a sêlo, tornando-se, o pai, seu rival. Entretanto, Freud chama a atenção para o que acontece com a menina, uma vez que seu primeiro objeto de amor foi também sua mãe, e interroga como ela achará o caminho até o pai e, ainda, quais são as consequências desse percurso.

Com a incidência do complexo de castração, porta de entrada do conflito edípico, a menina se encontra numa posição complexa, na qual a ambiguidade se faz 
marcante no encontro com sua mãe. Dafunchio (2013) afirma que os limites do complexo de Édipo na mulher são difusos e vagos, uma vez que "não encontra, do lado da sexualidade feminina, nenhum equivalente da ameaça de castração no menino. A ameaça de castração para uma mulher não é consistente, não toca o real de seu corpo, então não há nenhuma razão para que ela acabe de sair do Édipo" (p. 08).

Para Freud (1923/1987), é ao se deparar com a castração materna que o fantasma da ameaça de ter seu órgão castrado se apresenta para o menino, enquanto para a menina o que se apresenta é a constatação de sua condição feminina e a consequente transferência de investimento para a figura do pai.

Freud ensina que o complexo de Édipo no menino termina de um modo radical, diante do encontro com a ameaça de castração, porque teme perder o órgão, que é tão importante para ele. Por isso decide abandonar a mãe como objeto e identificar-se ao pai. Freud ensina que, na menina, é a entrada no complexo de castração que produz a entrada no Édipo, quando ela verifica que não tem o falo, que não o terá e acusa a mãe por tê-la feito mulher sob o signo de uma grande hostilidade, do ódio que vai separá-la da mãe e vai em direção ao pai, como tábua de salvação (Dafunchio, 2013, p. 08).

A respeito do corte feito pelo pai, no Édipo, Freud (1931/1987) destaca a diferença de efeitos do complexo de castração na mulher e, com isso, elabora três destinos como possibilidades de desdobramentos para a menina na substituição de investimento da mãe pelo pai: a inibição sexual ou histeria, o complexo de masculinidade e a feminilidade. O primeiro diz respeito ao afastamento, por parte da menina, de seus desejos e fantasias sexuais. Assim, ao deparar-se com a castração materna, a menina se dá conta da sua própria castração, de que lhe falta o órgão pelo qual obterá prazer, inibindo-se na atividade fálica. No complexo de masculinidade, 
observa-se a dificuldade da menina em identificar-se com sua mãe ao reconhecê-la como castrada. Identifica-se, portanto, ao pai, enquanto possuidor do falo, colocando-se no lugar da mulher fálica, recusando-se a reconhecer sua própria falta. A feminilidade, por fim, seria, segundo Freud, a saída em direção à "sexualidade normal". A menina reconhece a mãe como castrada e, conseguindo abrir mão do objeto materno, identificase a ela, passando a desejar um filho do seu pai como substituto do falo e representante do desejo feminino. Freud afirma, portanto, que na mulher o complexo de Édipo não é dissolvido e sim criado por influência da castração e, com muita frequência, não é superado pela mulher.

Portanto, para Freud, a fase pré-edípica, de exclusiva ligação à mãe, assume na mulher uma importância bem maior do que no homem e ele relaciona a esse momento muitos fenômenos da vida sexual feminina. "Em suma, fica-nos a impressão de que não conseguimos entender as mulheres, a menos que valorizemos essa fase de sua vinculação pré-edipiana à mãe” (Freud, 1933 [1932]/1987, p. 148).

Lacan, no retorno que faz à obra de Freud, destaca a importância da função materna na problemática da distinção sexual, principalmente na ordenação fálica, fazendo circular a questão de ter ou não ter o falo em torno da mãe. Ao reconhecer a castração materna, interpretando-a como ausência de falo (não ter o falo), Lacan indaga como isso se inscreve no inconsciente de cada sujeito.

Segundo ele, nos textos A dissolução do complexo de Édipo, Algumas consequências psíquicas da distinção anatômica entre os sexos e Sexualidade feminina, Freud situa uma dissimetria no nível simbólico quando se trata do masculino e do feminino, uma vez que o sexo do homem ancora sua representação na simbologia do que já está lá nomeado de falo, enquanto o sexo da mulher “é forçado a tomar a imagem do outro sexo por base de sua identificação" (Lacan, 1955-1956/2002, p. 202) e essa 
identificação fálica sublinha a inscrição não-toda do feminino no campo da representação (André, 1994).

Para Lacan, esta é a questão que se coloca ao ser falante no tocante ao feminino (questão que enuncia o que ele irá desenvolver em seu ensino no tocante à sexuação): Diante da falta de um significante que represente o feminino no inconsciente, como irá movimentar-se a menina no campo do desejo do Outro? E como irá estabelecer-se o tronar-se mulher para a menina na relação com a mãe?

\subsection{Uma menina, sua mãe e o grande Outro}

Uma menina ama sua mãe porque um dia teve nela seu primeiro e único objeto de amor e, mais ainda, um dia imaginou ser seu único e perfeito amor. Uma menina ama sua mãe porque foi nos braços dessa mulher que um dia foi passiva, seduzida, introduzida no circuito sem fim que começa na satisfação das necessidades vitais e desemboca nas tentativas de realização de desejos. Uma menina ama masculinamente a sua mãe, até que comece a odiá-la e, então, comece a se tornar mulher (Kehl, 1996, p. 109).

Da mãe como grande Outro à mãe castrada, do saber de uma mãe ao desejo de uma mulher, o que se passa entre elas, a menina e sua mãe, no tocante à posição feminina? Para falar do lugar crucial que a mãe ocupa na vida da menina e de como esta primeira relação implica na organização sexual e psíquica de uma mulher, Freud (1931/1987) enfatizou as relações pré-edípicas, os primeiros cuidados e afetos, como fundamentais para o desenrolar da relação mãe e filha. Lacan irá enfatizar como crucial, nessa relação, o momento em que a menina se depara com um ponto enigmático no desejo da mãe, momento em que reconhece na mãe algo que diz respeito a sua condição de mulher. 
Malvine Zalcberg (2003), no livro A relação mãe e filha, discorre sobre as peculiaridades dessa relação, enfatizando a diferente posição ocupada pela menina, em relação ao menino, no tocante à figura materna, na construção da subjetividade da mulher. Sendo a mãe a primeira referência na vida de um ser humano, ela assume o lugar de satisfazer as necessidades e suscitar as demandas na criança. Freud se refere à imensidão materna no ponto em que Lacan situa o primeiro grande Outro para a criança, o Outro primordial, lugar de ancoragem do corpo e da linguagem, no qual se dá um enodamento a partir do qual o sujeito pode constituir-se.

O grande Outro é uma instância simbólica que situa o sujeito no mundo, na relação com os outros sujeitos, no uso do código da língua e na apropriação do corpo. É uma instância de fundamental importância para a psicanálise por ser no campo do Outro que se constitui a subjetividade e por estar aí situada a cadeia da fala, instrumento usado pela psicanálise como via de acesso ao inconsciente.

No desenvolvimento da criança e no processo de tornar-se sujeito, com uma subjetividade própria, o Outro assume duas posições: a primeira ocupada pela mãe, de quem depende física e psiquicamente, por vir ao mundo numa condição de total desamparo, sem atribuições inatas que lhe auxiliem no desenrolar de sua relação com o mundo e com seu corpo. Assim, "o fato de a mãe poder atender às necessidades tanto biológicas quanto amorosas da criança constitui um dos motivos pelos quais a mãe é elevada à categoria de Outro" (Zalcberg, 2003, p. 60). A segunda posição depende da separação da unidade mãe-bebê, para que o Outro seja instaurado como uma instância simbólica, para além da mãe. Lacan enfatiza ser esse o ponto central do que se dá no complexo de Édipo, qual seja, a inscrição do sujeito no campo do Outro, do que decorre a maneira como o sujeito se situa como homem ou como mulher na dinâmica psíquica. 
É verdade que a mãe, elevada à categoria de Outro, não é este Outro. Ela apenas o encarna. O fato de a mãe encarnar o Outro para a criança é um dado da maior importância para o seu desenvolvimento, embora a criança vá destituí-la mais tarde desse lugar que ocupa (Zalcberg, 2003, p. 60).

No texto Sexualidade Feminina, Freud (1931/1987) se detém na forte ligação da menina com a mãe e enfatiza dois pontos importantes. Primeiro, o que se estabelece de forma prolongada na fase pré-edípica, no âmbito dos investimentos libidinais e sedutores dos primeiros cuidados maternos de amamentação e de higiene que a criança vive de forma passiva. Segundo, pela iniciação na atividade fálica que também se dá em relação a sua mãe, assim como no menino, uma vez que as condições primordiais da escolha de objeto são as mesmas para todas as crianças. A menina, inicialmente, ama masculinamente a sua mãe, como o menino, o que prevalece é a força ativa em ambos, quando, em um segundo tempo, a menina terá que fazer esse deslocamento para o feminino.

Para Freud, a fase pré-edípica é responsável por muito do que se dá como consequência da relação entre elas - a menina e sua mãe - para a vida sexual feminina, afirmando que algumas mulheres ficam detidas nessa relação, sem efetuarem uma transferência de investimento para os homens. Para ele, a relação da menina com o pai é apenas herdeira de uma ligação com mãe que foi a original, atribuindo a essa travessia a possibilidade de assunção a uma posição feminina.

No complexo de castração, uma primeira atestação se dá e se dá pela via da mãe. A descoberta da castração materna é determinante na menina, pois o seu investimento libidinal e amoroso pela a mãe, nesse momento, está voltado para a mãe fálica, potente, completa. Entretanto, diante da castração da mãe, ela se depara com uma falta de falo, falta que aparece junto com um desejo fálico, que se encontra para além da criança, e 
com um desejo que se encontra para além do falo. Esta constatação faz surgir, na cena da relação exclusivamente maternal, uma posição de mulher, um desejo feminino que a criança não satisfaz.

Soler (2005) afirma ser o surgimento do desejo feminino, na cena da criança, o que cria a ausência da mãe, pois ele descortina a dialética da separação: "na medida em que é mulher, a mãe não é toda para seu filho" (p. 100). A divergência entre ser mãe e ser mulher coloca, por um lado, a mãe no campo da falta fálica, apontando que o ser mulher, da mãe, "não se ocupa inteiramente do filho fálico" (p. 100); por outro lado, o desejo de mulher aponta para um gozo a mais, para além do falo, um gozo enigmático, que permanece indecifrável, do qual trataremos no tópico seguinte sob o nome de gozo feminino.

Ao deparar-se com a falta no Outro materno, a menina enfrenta uma dupla falta: a impossibilidade por parte dela de suprir a falta de falo materna, e outra que se faz enigma sem inscrição, como um gozo do qual nada se sabe. É um momento de opacidade, pois, sendo o desejo da mãe desejo de falo, como a filha supunha, ela não poderá satisfazê-lo, já que, como sua mãe, não o têm e não o terá nunca. É certo que ninguém tem o falo, nem meninas, nem meninos, nem a mãe, nem o pai, mas no que concerne ao significante, o pai e o seu herdeiro, o menino, encontraram no falo a representação necessária para a força de seu órgão e para seu posicionamento como homem, primeiro frente à mãe, depois frente a uma mulher de sua escolha. E, ainda, ao notar na mãe um para além do falo, ela depara-se com um vazio de compreensão, isto é, vazio de sustentação.

A menina que, primeiramente, tanto quanto o menino, se apoiou no falo descobre-se, assim como sua mãe, não-toda representada por ele e, portanto, dirige-se ao pai pedindo que lhe dê o falo tão desejado. É a partir da entrada da mãe como 
castrada que sua herança passa a ser odiada pela menina, que acredita herdar uma falta no lugar do falo e que isso concerne a sua semelhança com a mãe e, portanto, a algo do feminino. No entanto, é, justamente, a passagem da mãe como grande Outro à mãe castrada - uma destituição - que abre as portas ao Édipo.

É na decepção que Freud vê a mola da entrada da menina em sua posição feminina. A saída de sua fase fálica é gerada por essa decepção, um desvio que a seus olhos se fundamenta, no entanto, num mecanismo natural, e é nesse momento, diz ele, que o complexo de Édipo desempenha o papel normativo que tem de desempenhar, mas o desempenha, na menina, inversamente ao que acontece no menino. O complexo de Édipo lhe dá acesso ao pênis que lhe falta, por intermédio da apreensão do pênis do varão, quer ela o descubra em algum companheiro, quer o situe, ou o descubra igualmente, no pai (Lacan, 19571958/1999, p. 287).

O desdobramento do lugar materno para a menina, portanto, ocorre no Édipo, na forma de um deslizamento para o pai, fazendo-o de modo incompleto (Freud, 1931/1987). O complexo de Édipo, na menina, não é destruído, mas sim criado por influência da castração. Se a menina direciona seu amor para o pai, é com referência à mãe que o faz, pois, “o retorno à mãe, com toda a ambivalência dessa relação, mantémse inelutável no destino da filha" (André, 1994, p.179).

Nesse momento, a atividade da menina volta-se para o afastamento em relação à mãe e isso está ligado ao fato de sua mãe tê-la feito da mesma substância faltosa que a sua. Freud ressalta que essa ligação à mãe precisa mesmo ser atenuada com a presença do pai, uma vez que é de grande intensidade e que, mantendo-se acesa, compromete o percurso da menina em direção à assunção de sua própria condição feminina. A 
ambivalência amorosa da menina com a mãe, nessa fase, é claramente uma regra e é ela que impele ao afastamento, afirma Freud (1931/1987).

Nos textos de 1931, A sexualidade feminina, e de 1933 [1932], A feminilidade, Freud ressalta ser essa ambiguidade amor-ódio, que se instala na relação primitiva da menina com a mãe, aquilo que constitui uma catástrofe ligada ao destino do falo, na sexualidade e na subjetividade da menina. Ele enfatiza que a intensidade do ódio da filha está relacionada à intensidade do amor, que o precede, e à decepção (Marcos, 2011).

O que solicita da mãe, a menina? Quais são as incidências e as consequências da relação mãe e filha, para a condição feminina? Ouvimos na clínica os relatos sempre complexos nos quais a mãe aparece em um lugar crucial. É o lugar da origem da vida e dos conflitos, da semelhança e da diferença. Portanto, é sem dúvida um lugar de árduo trabalho, de separações e de costuras. Soler (2005) enfatiza que, na psicanálise, a questão materna é interrogada e explicada de diversas formas, a começar pelos ditos dos próprios analisandos.

O que se diz dela? Imperiosa, obscena e possessiva, ou, ao contrário, indiferente fria ou mortal, demasiadamente isto ou aquilo, atenta ou distraída demais, quer sature, quer prive, quer se preocupe, quer negligencie, tanto por suas recusas quanto por suas dádivas, ela aparece como a imagem das primeiras angústias, o lugar, ao mesmo tempo, de uma ameaça obscura e de um enigma insondável (p. 98).

A mãe está sempre presente no inconsciente, na forma de representações que se inscrevem e a partir da maneira como o filho a vivenciou, a fantasiou e a interpretou. A menina, no percurso de sua história, irá demandar da mãe uma inscrição inconsciente do 
que é ser mulher, na forma de um significante que a represente, o qual seja próprio do feminino e com o qual ela possa se identificar.

Entretanto, esse significante não existe, não está no campo simbólico, isto é, na ordem da palavra. Esse traço que constitui o feminino está fora do campo da significação e, por isso, faz emergir o real enquanto lugar de sua morada. É ao discorrer sobre o custoso processo que se passa entre a menina e sua mãe que Lacan relaciona o feminino à devastação, salientando que, por haver uma falta de nomeação e de inscrição significante, quando se trata do feminino, a mulher estabelece uma relação particular com o registro simbólico, submetendo-se não toda a ele. Isso convoca um além do simbólico no qual a menina situa o enigma do gozo feminino de sua mãe, ali onde a filha supõe que ela goza como mulher.

A menina - ao ver surgir na mãe um olhar para além dela, algo que não se satisfaz com a filha e que, portanto, não é da ordem do falo - vê-se desertada por essa mãe que aparece portando um gozo completamente enigmático - dá-se a devastação. A falta do aparato simbólico, de uma palavra que pudesse oferecer uma significação, faz a menina deparar-se com o real do corpo materno. Zalcberg (2003) salienta que esse mistério sobre a sexualidade da mãe fascina a menina e a faz ficar envolvida na presença amorosa e sexual da mãe enquanto mulher, pois a menina procura esse ponto enigmático de desejo no corpo da mãe e o que encontra é uma falta, não a falta de um "pênis real e sim, aquele que a mãe deveria ter e não tem, isto é, um significante que represente o sexo feminino, como o homem o tem: o falo" (p.150). Assim, esse lugar sem definição no corpo materno passa a representar, para a menina, um véu que encobre a falta, o que, ao mesmo tempo, a fascina e a paralisa.

Esse véu encobre a nudez, ali onde reside algo sem nomeação, sem inscrição simbólica, confrontando a menina com esse aspecto particular do feminino: "a imagem 
do que seria específico da mulher é inexistente” (Zalcberg, 2003, p. 150). A devastação, sempre catastrófica, se realiza quando a menina se depara com um ponto enigmático no desejo da mãe, ponto em que reconhece na mãe um desejo de mulher e não sabe o que fazer com isso.

Segundo Marcos (2011), a devastação comporta duas faces: a face fálica que faz a menina manter-se na demanda à mãe que lhe dê um lugar de falo em seu desejo; e uma face não toda fálica que se revela como um apagamento, um rapto do corpo, uma ausência de si, que se instauram diante da impossibilidade de simbolização do gozo feminino. De um lado a menina busca manter a mãe no lugar de mãe fálica, lugar do Outro, sustentando a ilusão da mãe total, completa. De outro, a ausência da filha no olhar do Outro materno opera um desaparecimento da filha que resta suspensa, sem lugar para ser, demandando ao desejo da mãe uma resposta para seu ser.

Na insistência da menina em encontrar no corpo da mãe a imagem da mulher, uma imagem fascinante de mulher, funde-se com a da mãe. Nessa fascinação pela imagem da mãe como mulher, Lacan situa a devastação como uma consequência da permanência da filha na relação especular com a mãe, numa insistência em não metaforizar a falta do Outro materno. Entretanto, manter a mãe no lugar do grande Outro ofusca, apaga a singularidade da menina, não havendo outra saída a não ser a de objeto.

Ao trazer a obra de Marguerite Duras, Le ravissement de Lol V. Stein., para a leitura psicanalítica, Lacan (1965/2003) enfatiza a função do olhar na delimitação e sustentação do corpo pelo sujeito. O olhar do Outro que investe e reveste o corpo físico, pedaço de carne, conferindo ao corpo uma imagem a partir da qual o sujeito, podendo ver-se refletido como num espelho, pode assumir uma imagem como sua. 
Só quando a criança recebe uma cobertura imaginária é que se pode ver: isto é quando se torna imagem e se assegura dela. Se o outro não a vê, a criança não vê nada; simplesmente porque não há nada para ver, já que como objeto, ela não tem existência. É preciso que o olhar ou o sorriso de sua mãe digam, de alguma maneira, à criança: ei-la (Zalcberg, 2003, p. 151).

$\mathrm{Na}$ falta de um significante que represente o feminino, a menina fica mais cativa desse olhar para sustentar seu corpo numa imagem, pois é a cobertura imaginária que dará suporte ao seu corpo. A menina empenha-se em se tornar o ser desejado por essa mãe, objeto de seu desejo, direção do seu olhar, reivindicação fálica que faz entrar na cena o pai como portador da lei simbólica - mediada pelo falo - que vem metaforizar a relação imaginária em que se encontram mãe e filha. No entanto, não sendo o desejo da mãe inteiramente recoberto pelo significante - falo - não é inteiramente significado pela intervenção simbólica do pai. Permanece uma parte obscura, onde a filha acredita estar a marca do feminino.

Lacan nomeia essa parte irredutível ao desejo - portanto, ao simbólico - de gozo feminino, um gozo a mais, suplementar, mais além do falo. É no seminário Mais, ainda que Lacan (1972-1973/1985) desenvolve o tema do gozo feminino a partir das fórmulas da sexuação. As fórmulas vêm apresentar esse campo do real, fora do alcance da palavra, onde estamos situando a noção de irrepresentável, proposta neste trabalho.

\subsection{De uma mulher à outra: o feminino}

Entre elas se passam muitas coisas: fantasias imaginárias, identificações, rivalidades, idealizações, construções simbólicas, enigmas e aflições. Aflição de contradizer-se em seus desejos, de gozar com os olhares alheios, de revestir-se de penduricalhos em torno de seu vazio, de querer ser $A$ mulher e de perceber que esta não 
existe. De uma mulher à outra se imprime o impossível e se interpõe o resto. O que resta da subtração da idealização d'A mulher é a unicidade de cada mulher, o traço no qual o seu gozo insiste em não se inscrever totalmente na lógica fálica, na metonímia do desejo, um gozo que desfaz o universal e tende ao infinito.

Partimos do estudo de Freud sobre a histeria, responsável pela fundação da psicanálise e por um olhar diferente acerca do feminino, para, aqui, introduzirmos a leitura e o desenvolvimento feito por Lacan no tocante ao feminino. Freud nomeou de enigma da feminilidade aquilo que ficou como uma questão em seu ensino: $O$ que quer a mulher? Em 1932, no texto A feminilidade, Freud propõe ser essa uma das saídas da menina frente à castração materna, a saída em direção à "sexualidade normal", onde a menina reconhece a mãe como castrada e, conseguindo abrir mão do objeto materno, se identifica a ela, passando a desejar um filho do seu pai. A castração materna, como vimos, inscreve um enigma tanto na menina como no menino, um enigma que se forma a partir de um traço inapreensível em face à tentativa das crianças de simbolizá-lo.

Lacan nomeia de enigma do gozo feminino aquilo que formula acerca dessa interrogação colocada por Freud e convoca a lógica do não-todo para abordá-la. Em substituição à expressão a mulher, do questionamento freudiano, Lacan refere-se a uma mulher para, com isso, elaborar suas formulações acerca da unicidade de cada mulher, explicando que no campo do feminino não há possibilidade de uma representação universal.

É para onde aponta o enunciado de Lacan: A mulher não existe. Dessa forma, somente é possível escrever $A$ mulher, colocando a barra sobre o $A$ - "a barra mostra que a mulher está divida, desdobrada, partida em seu gozo" (Dafunchio, 2013, p. 27). Essa proposição vem enunciar o que está explicitado nas fórmulas da sexuação: enquanto no lado masculino há uma exceção “x” que não está na função fálica - \$x $\overline{\mathbf{\Phi x}}$ 
-, no lado feminino não há essa exceção. No lado masculino, a exceção de ao menos um não regulado pela função fálica nos coloca diante do pai da horda primeva de Totem $e$ Tabu, um pai que, tendo acesso a todas as mulheres, concentrava um gozo ilimitado, não regulado pela lei fálica. É o assassinato do pai o que funda uma lei: a castração, que impõe limite ao gozo dos demais homens da tribo. O pai morto se torna o símbolo dessa lei, a exceção que funda o conjunto dos homens regulados pela lógica fálica.

O que dizer do que se passa do lado feminino? Dizemos, com Lacan (19721973/1985), que quando se trata do lado feminino, não existe uma mulher x que esteja em posição de exceção, ou seja, não existe $A$ mulher enquanto exceção, uma como o pai da horda primeva que inaugure o conjunto das mulheres. Todas as mulheres são marcadas pela função fálica de uma maneira particular - não-toda recoberta pelo falo. Lacan, portanto, situa as mulheres como participantes do gozo fálico, mas aponta onde incide a diferença: para além do falo, há um gozo que escapa ao fálico, estando, a mulher, não-toda inscrita na lógica fálica. "Não é porque ela é não-toda na função fálica que ela deixe de estar nela de todo. Ela não está nela não de todo. Ela está à toda. Mas há algo a mais" (LACAN, 1972-1973/1985, p. 100).

Esse Outro gozo, para além do falo, é o gozo feminino, que Lacan (1971/2009, 1973-1974/1985) nomeia de suplementar e pelo qual abordará a diferença entre o feminino e o masculino, recorrendo - no Seminário 18, De um discurso que não fosse semblante, e no Seminário 20, Mais, ainda - à lógica para a elaboração das fórmulas da sexuação. Ele afirma que o ser falante, qualquer que seja ele, irá necessariamente se posicionar em um dos lados apresentados no quadro abaixo: do lado esquerdo está situado o masculino e do lado direito, o feminino. 


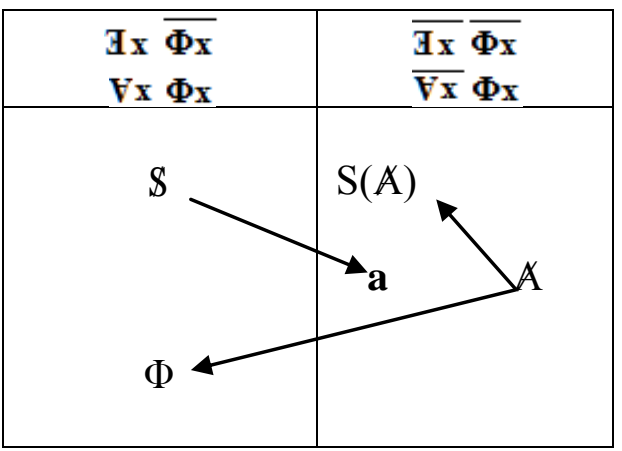

Quadro 1: Fórmulas da sexuação

Fonte: LACAN, 1972-1973/1985, p. 105.

A respeito dos símbolos que compõe esse quadro, temos: $\mathbf{x}$, uma variável que representa os seres humanos, a humanidade; dois quantificadores, o existêncial, $\exists$, e o universal, $\forall$; o falo, $\boldsymbol{\Phi}$, "significante que não tem significado, aquele que se suporta, no homem, pelo gozo fálico" (Lacan, 1972-1973/1985, p. 109); o \$, com o qual Lacan designa o lugar do homem; o objeto $\boldsymbol{a}$, noção desenvolvida por Lacan, que vem a marcar a dissimetria entre as posições masculina e feminina na sexuação - o objeto $a$ faz referência ao objeto perdido, como definido por Freud, do qual o sujeito se separa em sua constituição e que passa a ser representado na série de objetos que constituem a cadeia de seu desejo, sendo, portanto, o objeto causa do desejo; o A, lugar de $\mathbb{A}$ mulher, do qual não se pode dizer e que tem relação com $\mathbf{S}(\mathbf{A})$, significante da falta no Outro e no qual Lacan localiza o gozo feminino.

$\mathrm{Na}$ parte de cima do quadro há quatro fórmulas proposicionais. No lado masculino, a fórmula $\mathbf{V x} \mathbf{\Phi x}$ - para todo $\mathrm{x}$ há função fálica - “indica que é pela função fálica que o homem como todo toma inscrição" (Lacan, 1972-1973/1985, p. 107). Acima desta fórmula há outra $\mathbf{G}_{\mathbf{x}} \overline{\mathbf{\Phi} \mathbf{x}}$ - existe ao menos um x que não está na função fálica - “aí está o que chamamos função do pai” (p. 107), que, como exceção, faz surgir o conjunto que representa o todo masculino.

No lado feminino, a fórmula $\overline{\mathbf{V x}} \mathbf{\Phi} \mathbf{x}-$ uma mulher $\mathrm{x}$ está não-toda na função fálica - trata do que tange ao feminino, que uma parte da mulher está na função fálica, 
como todo ser falante marcado pela castração, há, no entanto, outra parte que não está lá, que se encontra alhures, para além do falo. A fórmula que se encontra acima, $\overline{\mathbf{J}_{\mathbf{x}}} \overline{\mathbf{\Phi}_{\mathbf{x}}}$ - não existe uma mulher x que esteja em posição de exceção -, aponta para a falta de uma exceção que concentrasse nela um gozo não regulado pelo falo, e o fato de não haver a exceção faz com que as mulheres, uma a uma, tenham acesso, também, a esse gozo.

Em baixo, sob a barra transversal, têm-se uma representação mais detalhada do que se vê na parte de cima do quadro. No lado esquerdo - masculino -, o campo do sujeito $\$$ aparece todo representado pelo falo $\boldsymbol{\Phi}$ e, assim, temos a seta que parte do sujeito $\$$ dirigindo-se ao objeto $\boldsymbol{a}$, na medida em que é esse objeto que causa o seu desejo. O objeto $\boldsymbol{a}$ está localizado do lado feminino sendo, portanto, na condição de objeto $\boldsymbol{a}$ que o homem toma a mulher como causa de seu desejo.

Esse \$ só tem a ver, enquanto parceiro, com o objeto $a$ inscrito do outro lado da barra. Só lhe é dado atingir seu parceiro sexual, que é o Outro, por intermédio disto, de ele ser a causa de seu desejo. A esse título, como indica alhures em meus gráficos a conjunção apontada desse $\$$ e desse $a$, isto não é outra coisa senão a fantasia. Essa fantasia, em que o sujeito é preso, é, como tal, o suporte do que se chama expressamente, na teoria freudiana, o princípio de realidade (Lacan, 19721973/1985, p. 108).

A fantasia é o que atribui alguma possibilidade - possibilidade simbólica - à relação impossível que exite entre o sujeito e o objeto. Entre o sujeito e o objeto $a$ há o real, como um abismo que marca a condição do objeto, desde Freud - o objeto perdido. É pelo fato do objeto ser um objeto perdido que o ser falante se utiliza da linguagem para tentar abordá-lo, recorrendo ao registro simbólico para articular, por meio da 
contrução da fantasia, o seu desejo, qual seja: procurar este objeto que, não sendo encontrado nunca, continua funcionando como aquilo que causa seu desejo.

Assim, se o lado masculino se dirige ao feminino tomando-o como objeto $a$, o faz apoiado em sua fantasia, uma vez que é a fantasia do homem que resveste uma mulher de objeto $a$, atribuindo-lhe o lugar de causa de seu desejo. É nesse ponto que Lacan situa seu enunciado - A relação sexual não existe -, pois há um impossivel que marca a falta de proporção entre o que de desdobra em um lado e outro do quadro.

No lado direito - feminino -, a mulher está representada pelo $\mathbf{A}$, evidenciando sua relação mais direta com o grande Outro (A) que, enquanto registro simbólico, é marcado pela falta de um significante que represente A mulher, o que torna possível haver um gozo que escape à regulação fálica. Do lugar d'A mulher partem duas setas: uma em direção ao falo $\boldsymbol{\Phi}$ que está localizado do lado masculino, o que a faz transitar pelo gozo fálico; e outra em direção ao Outro gozo - o gozo suplementar, $\mathbf{S}(\mathbf{A})$, que permite à mulher gozar de uma ausência (Dafunchio, 2013).

Marie Pesenti-Irrmann (2006), no texto La mère et Le féminin, diz que a mulher testemunha muitos excessos - excesso de setas, de traços, de letras. A mulher se movimenta com uma seta em direção ao gozo fálico e com outra seta em direção ao gozo suplementar, o que faz situar, no lado da mulher, em uma mesma altura, o $\mathbf{A}$ e o objeto $\boldsymbol{a}$. O objeto $\boldsymbol{a}$ aqui se inscreve como semblante de ser e vem promover o encontro com o parceiro, por meio do gozo comum aos dois lados - o fálico, num movimento pela mulher de ocupar o lugar de causa do desejo do homem.

Sendo pela lógica da fantasia que o masculino aborda o feminino, o homem, que acredita gozar do corpo de uma mulher, goza de sua fantasia e, assim, movimenta seu desejo. Afinal, por funcionar todo inscrito na lógica fálica, “o homem tenta fazer entrar na dimensão de objeto tudo o que lhe escapa" (Dafunchio, 2013, p. 22). 
Do lado feminino, o gozo fálico de uma mulher a faz dirigir-se para o homem enquanto objeto $a$ e, com isso, garante a fantasia masculina, por colocar o homem no lugar fálico, de possuidor do falo. A mulher não tem o falo, o que confere a seu acesso ao falo um estatuto diferente do ter. Ela se presta a ser o falo, o que só é possível na ordem do semblante. Fazer-se semblante de falo é a maneira de uma mulher comparecer à relação com um homem. Nesse nível de gozo há uma complementaridade, onde um busca, no outro, o falo e a castração, havendo sempre um resto. "Mas há um nível no corpo onde não há complementaridade, que é de onde se encontra o Outro gozo. Nessa vertente não há complementaridade, porque é um gozo ao qual somente uma mulher tem acesso" (Dafunchio, 2013, p. 28).

No seminário Mais, ainda, Lacan (1972-1973/1985) usou o termo suplementar, para falar deste gozo feminino que não recai no todo e que aponta para o vazio no simbólico, isto é, para a falta de um significante que represente o feminino simbolicamente. Por isso, Lacan o situa como um gozo o qual a mulher experimenta, mas não pode saber nada sobre ele - "uma mulher goza em solidão, para além do gozo que ela tem com um homem" (Dafunchio, 2013, p. 28).

"O Outro não é simplesmente esse lugar onde a verdade balbucia. Ele merece representar aquilo com que a mulher tem fundamentalmente relação" (Lacan, 19721973/1985, p. 108). Uma mulher está na relação fálica com o homem, mas está também numa relação mais estreita com o Outro, na medida em que é a própria existência feminina que lhe confere uma falta radical, um buraco simbólico ali onde não há, no campo do Outro, um significante que represente a mulher. É aí que uma mulher se dirige, na fórmula da sexuação, ao $\mathbf{S}(\mathbf{A})$, esse lugar desertado do significante d'A mulher, extraindo dele um gozo, um Outro gozo, gozo suplementar. 
Ao falar do gozo suplementar, Pesenti-Irrmann (2006) ressalta a posição da mulher diante desse gozo e questiona se ocupar essa posição pode ser chamado de um privilégio. Para ela, se trata de uma tensão com a qual a mulher é confrontada e a qual não pode evitar. Enquanto o homem pode, durante muito tempo, se apoiar na lógica fálica, isto é, no sentido, a mulher é convocada constantemente a fazer algo com o buraco no Outro, o que a obriga a produzir, sem cessar, uma solução para essa inscrição simbólica não-toda. Ela é confrontada com a falta de um significante que a represente toda simbolicamente. $\mathrm{O}$ simbólico, contudo, enquanto um registro que recobre a lógica fálica, não dá conta da porção feminina, que excede essa lógica, sendo da ordem de um real, fora da linguagem, que não se deixa apreender pelo simbólico e que insiste mais e mais, ainda.

Segundo a autora, esta busca pode conduzir a mulher a uma devoção à causa fálica ou o oposto, viver uma desapropriação de si, não ser nada, vivendo isolada de todas as coisas, como testemunha Santa Thereza d'Ávila, a mística a qual Lacan (19721973/1985) faz referência no seminário Mais, ainda, como uma indicação da existência desse Outro gozo: "basta que vocês vão olhar em Roma a estátua de Bernini para compreenderem logo que está gozando, não há dúvida” (p. 103).

Assim, se o feminino, como um continente enigmático, existe, é entre esses dois gozos que devemos procurá-lo, onde reside a questão marcada por Freud e retomada por Lacan sobre o que quer a mulher. Ainda, segundo Pesenti-Irrmann (2006) essa é uma questão que se coloca como enigma para todos os sujeitos, tanto do lado do homem como do lado da mulher, mas, sobretudo, é um enigma para as crianças, uma vez que a questão se coloca no nível da mãe, no qual a criança só consegue apreender a dimensão fálica, o que a faz supor existir, na mãe, um desejo que resta a desejar. Após a travessia do Édipo, é com essa parte do desejo da mãe que o sujeito irá se confrontar, o centro 
mesmo do desejo da mãe, que já não se confunde com a castração materna. Entre a mãe e a mulher existe um hiato, pontua Soler (2006), pois para além da maternidade, "Lacan procedeu a uma espécie de dedução de um desejo feminino específico” (p. 53).

Se, para Lacan (1972-1973/1985) A Mulher não existe, todas elas sim, é isso que se diz ao colocar uma barra sobre o A - A mulher. Sua formulação se dirige para a não existência d'A Mulher que totalizasse o gozo de todas as mulheres e, com essa construção, admite o irrepresentável como próprio do feminino. É aqui que surge a questão da sexuação: só há um sexo, pois o feminino, enquanto Outro sexo, não comporta uma representação, é uma parte que faz objeção ao universal da função fálica, que não é generalizável nem possível de apreender a não ser tomando cada mulher uma a uma (Pesenti-Irrmann, 2006). Não havendo uma exceção que funde o universal feminino, ele surge como um buraco no Outro, que só pode ser tomado em sua singularidade, como uma parte a ser inventada por cada sujeito em sua história.

A relação entre o feminino e o irrepresentável desenvolvida nesse trabalho refere-se, portanto, ao conceito lacaniano de gozo feminino - gozo suplementar -, do qual nada se pode falar. Isso acontece, não por ser censurado falar ou por se tratar de algo recalcado, mas, justamente, por ser um gozo que escapa à palavra, que está para além da lógica fálica, um gozo que não está inscrito no fluxo discursivo e, portanto, no simbólico. É no registro do real, que desenvolvemos de maneira mais detalhada no capítulo seguinte, que Lacan situa o gozo suplementar, gozo do corpo, que se apresenta de forma ilimitada.

Entendemos que o engajamento de Lacan em demonstrar, por meio das fórmulas, a maneira como o ser falante se situa diante da diferença dos sexos enfatiza o que ele formaliza enquanto algo que não se escreve e que, não sendo possível ser articulado em termos de uma cadeia significante, convoca a letra, naquilo que ela traz a 
marca de uma inscrição particular que não se entregou à significação e permaneceu neste lugar do qual a angústia anuncia a proximidade: o real. O irrepresentável como aquilo que não é possível entrar no campo da representação, a não ser como enigma, convoca, para além do inconsciente em sua vertente simbólica, possível de ser interpretada, uma vertente real, em que reside um gozo do qual nada se sabe, a não ser que se experimente.

Como vimos, é no campo feminino que o não-todo vem marcar o lugar do irrepresentável, daquilo escapa à representação fálica. Há um vazio de significação naquilo que se refere ao Outro gozo, ligado ao feminino, - o suplementar. No capítulo seguinte, buscamos articular a maneira como esse irrepresentável se relaciona com a linguagem e, para tanto, convocamos algumas noções desenvolvidas por Lacan como a noção de real, de letra e de lalangue. 


\section{CAPÍTULO 2}

\section{O Irrepresentável: o traço real}

Eu queria pegar na semente da palavra.

Manoel de Barros ${ }^{3}$

\footnotetext{
${ }^{3}$ Manoel de Barros (2010, p. 81).
} 


\subsection{A Representação e o Irrepresentável}

A psicanálise, desde Freud, elegeu o inconsciente como campo de investigação. Ao atribuir ao inconsciente o que se dava na fala e na sintomatologia das histéricas, Freud introduz uma noção de inconsciente que não se confunde com a criação imaginante do inconsciente romântico. Lacan (1964/1998), no texto O Inconsciente freudiano e o nosso, marca as particularidades do inconsciente, tal como Freud o formulou durante seu ensino, enfatizando a delimitação rigorosa feita por ele, o que faz aparecer na cena do sujeito o funcionamento do inconsciente como uma estrutura tão elaborada quanto a do consciente.

Ao marcar a existência do inconsciente como parte da estrutura do parelho psíquico, Freud evidencia uma relação do homem com a linguagem extremamente singular e reveladora. Dos estudos das afasias, Freud destaca o conceito de representação a partir da não correspondência fechada entre o aparelhamento anatômico e o cerebral da fala e a utilização dela por parte dos falantes, fato confirmado na experiência clínica com as histéricas. Com a definição do inconsciente estruturado como uma linguagem, Lacan busca retomar a delimitação feita por Freud do aparelho psíquico como um aparelho de linguagem, do qual se organiza a subjetividade de cada sujeito. Nesse sistema de linguagem, impera a lei do significante, pois o que Freud formula a respeito das representações como constitutivas do psiquismo não gira em torno da correspondência entre um significante e um significado, mas sim em torno das associações entre diferentes elementos que produzem um efeito de significação que é singular a cada sujeito.

A representação tem função de inscrição simbólica das percepções, sensações, imagens e sons no campo psíquico. Esse movimento é estruturante, cabendo, aos elementos que participam da cadeia associativa que passa a se formar, a tomada de 
posição do sujeito na nomeação de seu corpo e de seus desejos. A histérica vai até Freud falar do seu corpo, do que o envolve e o paralisa, e o que Freud enfatiza na sintomatologia histérica é menos a anatomia corporal e mais a fala sobre essa anatomia. Isso demonstra o que chama a atenção de Freud, a saber, a maneira como essa anatomia foi representada e inscrita no psiquismo de acordo com as leis associativas da linguagem do inconsciente.

Para circunscrever a noção de representação e irrepresentável, fundamentais ao desenvolvimento do nosso trabalho, utilizaremos a formalização feita por Lacan dos três registros, definidos como fundamentais à estruturação do psiquismo e à maneira pela qual os seres humanos estabelecem relação entre si: o Real, o Simbólico e o Imaginário (RSI). A eles entrelaçaremos as noções de representação e de irrepresentável, articulando como acontece a passagem do imaginário ao simbólico na assunção e apropriação da fala pelo sujeito - portanto, ao campo da representação, destacando a maneira pela qual as experiências do sujeito são registradas em seu psiquismo - e o real, campo onde situamos a noção de irrepresentável, lugar do impronunciável, o centro incógnito em torno do qual circula o dinamismo do inconsciente.

É preciso ressaltar que o estudo e a delimitação dos três registros RSI permearam todo o ensino de Lacan e, embora não compareça com a mesma nomeação no ensino de Freud, foi nele que se baseou. Enquanto estruturante da subjetividade, esses registros operam de maneira entrelaçada, é o que Lacan teoriza com a nomeação de nó borromeo, os quais situaremos aqui, separadamente, com o intuito de clarear a exposição quanto aos momentos e elementos estruturantes do psiquismo.

Dafunchio (2013) explica que inicialmente os registros estão soltos, no que tange ao ser falante. O imaginário não está, de saída, articulado com o real do corpo, como acontece com o animal cujo instinto opera esta ligação. No ser falante, é a palavra 
que torna possível o enodamento da imagem com o corpo. Essa amarração, entretanto, não se dá de forma harmônica. Uma vez que o simbólico é sempre dividido, ele não alcança a totalidade da representação do corpo pela palavra. Os sintomas, no sentido analítico, estão aí para evidenciar essa disjunção, sobreposição ou fixação entre os registros, o que denuncia a amarração particular entre os nós para cada sujeito.

O imaginário é o campo do psiquismo no qual imagem e imaginação se encontram, inaugurando no humano um primeiro modo de relação. Lacan situa esse registro no campo da inscrição afetiva, onde o bebê começa a ser marcado pelo olhar e pela voz de seus pais - ou cuidadores - até que, já criança, comece a formar uma imagem de si. Essa imagem vem dar sustentação imaginária a um corpo que inicialmente está imerso em um despedaçamento natural - ele é a boca que suga, o objeto excrementício, o choro que convoca. O nascimento de um eu, enquanto uma unidade imaginária, é quando a criança "se conhece e se desconhece, e que é aquilo de que ele fala" (Lacan, 1955-1956/2002, p. 186).

A criança se encontra aqui em um domínio familiar, pois o seu $e u$ se organizou a partir de um espelhamento com a imagem de seus pais, carregada de afeto e de identificação. A imagem do adulto desempenha uma atração na criança, que ainda não tem controle de seus movimentos nem a apreensão da totalidade do seu corpo. Ela se alimenta da imagem dos pais enquanto imagem ideal, onipotente, na qual se vê primeiramente confundida - narcisismo primário - e da qual posteriormente poderá se ver diferenciada - narcisismo secundário - e, ainda sim, manter-se a ela vinculada.

A vivência de unidade que o bebê tem nesse momento, com a súbita obtenção de um contorno nítido e definido, estabelece a passagem da sensação de um corpo espedaçado, no qual há uma indiferenciação entre seu corpo e o de sua mãe, para a do corpo próprio (Jorge, 2008, p. 45). 
Estamos aí no reflexo da comunicação afetiva, da entrada da criança no universo discursivo, onde as significações, imantadas pela narrativa sedutora dos carinhos parentais, alcançam “de imediato as fontes da fabulação” (Lacan, 1955-1956/2002, p. 190). O contar de histórias que vai e vem, entrelaçando os desejos dos pais em relação ao filho às construções imaginárias que o filho faz a partir dessa narrativa, vai tecendo o esboço de uma imagem através da qual a criança começa a dirigir-se ao mundo exterior.

Para exprimi-la, as palavras vêm em abundância ao sujeito, elas estão à sua disposição, tão acessíveis e tão inesgotáveis em suas combinações quanto a natureza à qual correspondem. É o mundo da criança, no qual vocês se sentem à vontade, tanto mais que vocês foram familiarizados com as suas fantasias - o alto vale o baixo, o direito vale o avesso etc. A universal equivalência é a lei deste mundo (Lacan, 1955-1956/2002, p. 189).

Esse é o campo onde Lacan situa o terreno da ilusão em que ele também vê sedimentada a função discursiva da linguagem, algo que se relaciona com vistas ao ideal e à produção de sentido. É um domínio insondável, sobre o qual a psicanálise produziu avanços notáveis, mas está longe de dominá-lo. "Se o inventário analítico permite mostrar certos traços de economia essenciais da função imaginária, a questão nem por isso está esgotada" (Lacan, 1955-1956/2002, p. 190). Jorge (2008) ressalta o empenho de Lacan, em seu ensino, em estabelecer a distinção entre o $e u$ e o sujeito, afirmando que essa distinção tem sua base na diferenciação entre o imaginário e o simbólico.

Se o eu é da ordem do imaginário e do sentido, o sujeito é partido entre os significantes do simbólico. Isso equivale a dizer que a unidade obtida no eu não o é jamais no nível do sujeito, pois este é sempre dividido, conflitivo, impossível de se identificar de modo absoluto (Jorge, 2008, p.46). 
Seguindo Freud, vemos que as vias de acesso ao inconsciente não estão situadas inteiramente no plano imaginário, do $e u$, ao contrário, por mais profunda que seja uma exploração do $e u$, isso “jamais levará a um fenômeno do inconsciente como tal” (Lacan, 1955-1956/2002, p. 191). A prevalência da relação imaginária, em uma situação analítica, induz ao reforço do $e u$, a uma miragem referente ao ideal. O trabalho analítico, ao contrário, se dirige ao sujeito do inconsciente. Há uma barreira, uma barra que divide o $e u$ e o sujeito do inconsciente. É aí que a fala antecede o $e u$, no momento em que isso fala nele, quando das manifestações do inconsciente, fazendo surgir um sujeito como efeito do significante, envergonhado pelo seu ato falho, embaraçado pelo seu chiste.

O campo do inconsciente, portanto, rompe com o sentido linear. Não sendo da ordem do familiar, é da ordem do estranho, daquilo que fala no sujeito - campo esse, propriamente falando, o da experiência analítica. $\mathrm{O}$ inconsciente é fundado, enquanto tal, a partir da inscrição do sujeito no pacto simbólico instituído pela lei paterna, lei que é responsável pela instalação da subjetividade no sujeito, uma vez que vem metaforizar o imaginário a partir da colocação do significante.

A imagem do corpo tem, sem dúvida, função essencial na constituição do sujeito. A comunicação imaginária "é a soma das impressões internas ou externas, das informações que o sujeito recebe do mundo onde vive, das relações naturais que tem com ele" (Lacan, 1955-1956/2002, p. 189). Entretanto, é na medida em que a questão foi reencaminhada como simbólica, e não reativada como imaginária, que o sujeito nela se inscreve com sua subjetividade. $\mathrm{O}$ sujeito é convocado a responder às coisas da sua vida de outro lugar, do lugar de falante, não mais numa fala que lhe é alheia, mas, a partir desse momento, essa fala passa a ser marcada por sua subjetividade e passa a ter, portanto, uma referência inconsciente. 
A fala fundamental da experiência analítica se passa no plano da radical alteridade, é assim que Lacan delimita o campo do grande Outro, campo simbólico por onde o sujeito do inconsciente força sua passagem mediante o insistente funcionamento do circuito imaginário que faz resistência à comunicação analítica. Isso ocorre porque os pólos imaginários do sujeito recobrem a relação entre o eu e o outro, buscando a manutenção de uma suposta homogeneidade, característica da relação especular (Lacan, 1955-1956/2002). O registro imaginário sustenta uma relação passível de confusão no sentido do confundir-se com o seu reflexo no outro, o que confere um perigo à experiência analítica quando o analista, seduzido pela narrativa imaginária, se vê no sujeito como uma espécie de espelhamento.

Isso se produz da maneira mais natural se ele não é analisado - o que acontece de vez em quando, e direi mesmo que, por um certo lado, o analista jamais é completamente analista, pela simples razão de que é homem, e de que participa, ele também, dos mecanismos imaginários que dificultam a passagem à fala (Lacan, 1955-1956/2002, p. 186).

Lacan precisa que, na experiência analítica, o analista tem de ser bastante morto, para não se identificar com o sujeito, para não ser pego na sedutora relação imaginária, pois, no interior dessa relação, ele é solicitado a intervir de forma a sustentar a imagem do $e u$, imagem com a qual o sujeito se apresenta e que é um impedimento à fala analítica propriamente dita. A fala analítica se dá no circuito simbólico, por portar algo que se passa entre o sujeito e o Outro, como uma maneira de nomear a "coisa a revelar, a coisa que não tem nome" (Lacan, 1955-1956/2002, p. 186).

“O que o sujeito tinha a dizer através de seu falso discurso encontrará mais facilmente uma passagem à medida em que a economia da relação imaginária tiver sido progressivamente diminuída" (Lacan, 1955-1956/2002, p. 186). Pois a relação 
imaginária aprisiona o sujeito numa imagem que foi formada e que se movimenta numa relação de espelhamento com o ideal. A entrada no simbólico vem abrir a possibilidade ao sujeito de que sua fala tenha passagem (e, porque não dizer, ultrapassagem?) mediante a diminuição da força da relação imaginária. É aí também que a equivocação faz sua entrada.

Metaforizar o imaginário, imprimindo em seu lugar uma força simbólica, vem introduzir, na cadeia do sentido que se apresenta para o sujeito como linear, o duplo sentido, o equívoco, o tropeço, e assim por diante, evidenciando o próprio movimento da linguagem e libertando o sujeito de se situar em uma única nomeação feita por um significante primeiro que veio dar consistência a seu corpo, tirando-o da condição de um pedaço de carne. Assim fazem as mães e os pais com seus bebês, o nomeiam a partir de seus desejos, conferindo sentido, ritmo, sons, toques e, com isso, fazendo pulsar aquele corpo que acaba de chegar ao mundo. "O enredo fantasmático de ser falante, é o resultado da passagem do corpo orgânico ao corpo pulsional, este último sendo um efeito de linguagem" (Chatelard, 2005, p. 183).

A linguagem produtora de sentido, entretanto, caminha sempre para o fracasso e isso dá lugar a outros sentidos que se movimentam em um deslizamento, esta é a função da metáfora e da metonímia, essencialmente simbólicas que, ao substituir o Desejo-daMãe pelo Nome-do-Pai, introduz o sujeito no campo do desejo. O simbólico é, portanto, o campo da inscrição no psiquismo da lei que fará com que seja cumprido o que foi experienciado no complexo de castração: a interdição que instaura no sujeito uma perda, com a incidência de uma barra que substitui a ilusão da totalidade pela dimensão da falta como inerente ao ser falante. Este é o ponto em que a psicanálise produziu sua descoberta essencial, ponto em que a imagem é traumatizada pela incidência da linguagem. 
A barra sulcada pelo simbólico no jogo da relação imaginária faz entrar na cena do sujeito o mal-entendido, pois o que está em jogo no equívoco é o poder que gira em torno do significante, o qual se equivoca para convocar o inconsciente marcando a posição de alteridade, de diferença entre um sujeito e outro. Lacan enfatiza a importância de um discurso não ser completamente compreendido, pois a hiância que se abre entre o dito e o entendido faz surgir a função problemática da linguagem, estando a porta aberta para um novo posicionamento, uma nova nomeação, afinal "o próprio fundamento do discurso inter-humano é o mal-entendido" (Lacan, 1955-1956/2002, p. 188).

Jorge (2008) assinala que a barra incide sobre o eu causando uma spaltung, uma divisão que funda o sujeito do inconsciente, e, retomando Freud, enfatiza ser esta a questão fundamental que a psicanálise veio revelar: "que os homens não são senhores de si mesmos" (p. 17). O inconsciente, como um corte no discurso, introduz a lógica do significante no comando da estrutura da fala.

Freud, na construção e elaboração da noção de aparelho psíquico, situa o aparelhamento anatômico e o cerebral da fala no ser humano submetidos à subjetividade, destacando a relação não objetiva entre as palavras e as coisas, quando se trata do ser humano. Ao trazer a noção de representação para o cerne do trabalho do inconsciente, Freud atribui o comando das significações às associações, pois a coisa vivida, experimentada ou fantasiada, só encontra uma inscrição no psiquismo em forma de combinações e oposições entre diversos elementos. Isoladamente uma palavra não significa nada, não tem potência na trama do sujeito.

A elaboração freudiana a respeito do inconsciente apresenta uma forma inédita de pensar a relação do ser humano com seu próprio corpo e com a cultura, pois, a partir da descoberta do inconsciente como algo que aparece e desaparece na fala do sujeito, 
foi possível levar em conta o fato de a utilização da linguagem ser atravessada pela forma como as experiências se inscrevem no psiquismo. Para Freud, é o sujeito do inconsciente quem costura os elementos que passam pela sua cadeia de linguagem, associando-os, uns aos outros, de maneira muito singular. As discordâncias linguageiras presentes na fala do afásico, bem como na fala da histérica sobre sua sintomatologia eminentemente corporal -, deram a Freud a indicação da especificidade da relação do homem com a palavra.

Em o Inconsciente, texto de 1915, Freud (1987) traz uma diferenciação sobre a forma como se dá a inscrição psíquica no consciente e no inconsciente. Ele utiliza a noção de representação-coisa (Sachvorstellung) e de representação-palavra (Wortvorstellung) na construção da teoria do aparelho psíquico estruturado como uma linguagem. As representações inconscientes contêm os primeiros investimentos, as fantasias primárias do sujeito, e são inscritas no psiquismo na forma de representaçãocoisa. Quando estas representações se relacionam umas às outras e são sobreinvestidas por representações verbais, conferem uma estruturação ao psiquismo: o consciente estrutura-se a partir da ligação entre representação-coisa e representação-palavra, enquanto o inconsciente faz resistência à representação da coisa pela palavra e trabalha no sentido de manter afastado da consciência essas primeiras sensações e percepções, imprimindo força ao processo de recalcamento.

Na fundação do inconsciente, resultado da experiência do sujeito com o objeto perdido, um traço significante marca o sujeito, efetuando-se uma simbolização primordial em torno da qual ele passa a construir suas representações (Chatelard, 2005). No Seminário A ética da psicanálise, Lacan (1959-1960/2008) afirma que tudo o que pode ser formulado como atributo ou qualidade do objeto entra no investimento do 
sistema psíquico e constitui as representações primitivas em torno das quais estará o jogo de significantes, que se desdobram para inscrevê-las no psiquismo.

A questão da existência do objeto é colocada pelo sujeito em sua realidade psíquica a partir de suas representações, pois é a partir da marca deixada pelo objeto primordial e desse primeiro traço significante que o sujeito constrói suas representações - Vorstellungen - e chega aos atributos significantes do objeto inscritos na memória (Chatelard, 2005, p. 108).

O objeto, enquanto tal, não existe materialmente. Freud o nomeia de objeto perdido, relacionando-o a uma parte que se destaca do sujeito a partir de uma simbolização primordial. Essa simbolização primordial eleva o objeto ao estatuto de significante, marcando ser pela via da linguagem que o sujeito tentará resgatá-lo, sem nunca conseguir. O significante é, portanto, o elemento responsável pelas representações no psiquismo do sujeito e "a transferência de quantidade de Vorstellung em Vorstellung mantém a busca sempre a uma certa distância daquilo em torno do que ela gira" (Lacan, 1959-1960/2008. p. 74). É, portanto, no âmbito da relação entre o sujeito e o objeto que a psicanálise localiza a dissociação entre significante e significado, na linguagem do inconsciente. Não é possível haver um objeto que encerre a significação do desejo de um sujeito, assim como não há um significado que fixe um significante, ou seja, que o diga de forma completa e fechada. O que há de fato é uma maneira de articular o desejo na busca pelo objeto, de suscitá-lo, de representá-lo por meio do significante.

A estruturação do aparelho psíquico se dá, então, em torno das representações, que abarcam o percurso de uma informação desde a percepção até a inscrição no psiquismo. Isso faz aparecer na cadeia de linguagem de cada sujeito um modo singular de articulação significante. Há uma transformação operada pela subjetividade de cada 
sujeito no encontro com uma sensação, um afeto, uma ordem ou uma separação, isto é, não há como precisar a maneira como cada ser falante irá representá-los. As diferentes representações psíquicas (afetos, representação-coisa e representação-palavra), portanto, não são dadas de antemão pelo aparelho psíquico, elas são resultado de um trabalho de composição de modo a estruturar o psiquismo de cada sujeito de uma forma bastante específica, singular.

O psiquismo é destinado a forjar uma representação do real do corpo, o que, no entanto, só é possível a partir da constituição do $e u$, por ser esta uma instância que permite uma representação pela qual o sujeito pode existir. O $e u$ não é a mesma coisa do sujeito do inconsciente, no entanto, convoca o Outro a assumir seu papel de representar o sujeito por meio do significante, não sendo possível fazê-lo de forma completa. É nas manifestações do inconsciente que Freud se depara com uma hiância entre o eu, instância pela qual o sujeito se apresenta ao outro, e o sujeito do inconsciente, aquele que irrompe na fala à revelia do $e u$.

Lacan (1964/1998) enfatiza que essas manifestações (o sonho, o ato falho, o chiste e o sintoma) inquietaram Freud pelo modo de tropeço pela qual aparecem na fala do sujeito e o fizeram procurar e delimitar o inconsciente como uma coisa que quer se realizar e que se realiza em uma estranha temporalidade na fala do sujeito. Nas manifestações do inconsciente, está em jogo o momento em que a representação-coisa cede à representação-palavra, o que só pode ser feito na forma de um contorno, de uma aproximação no instante em que a representação-coisa está ali, na borda, a se deixar entoar pela palavra, nunca de forma completa. Pois o campo do Outro, enquanto campo da fala e da linguagem, funciona como campo da representação e, ao mesmo tempo, encontra nele mesmo o seu limite. Se uma palavra irrompe, provocando uma rachadura 
no discurso e causando surpresa ao próprio sujeito que fala, é porque, no campo do Outro, a função do significante não é suficiente para abarcar a representação do sujeito.

Sendo o inconsciente aquilo que rompe com o discurso, forçando sua passagem como uma fenda que se abre para o sujeito e marcando uma descontinuidade na formação discursiva do $e u$, não haveria de ser, por isso, a fala o instrumento propriamente psicanalítico? É na enunciação, no ato da fala, que o inconsciente força sua passagem "e que, numa interjeição, num imperativo, numa invocação, mesmo num desfalecimento, é sempre ele que nos põe seu enigma, e que fala" (Lacan, 1964/1998, p. 31). E o que fala o inconsciente quando se manifesta?

Tudo gira em torno de um ponto central. Sobre este ponto - nomeado por Freud de umbigo do sonho, ao tratar a respeito da interpretação dos sonhos - opera-se um apagamento dito de responsabilidade do trauma, a partir do qual Freud desenvolve o conceito de recalque. O umbigo do sonho é um ponto que não encontra representação na fala do sonhador por se tratar de um registro do psiquismo com cujo o sujeito tem um encontro essencial, para o qual é sempre convocado e do qual, no entanto, sempre escapole. Este registro, no qual Lacan (1964/1998) localiza a origem do trauma, é o real, que se apresenta sempre em um formato inassimilável para o sujeito. Onde, então, encontrá-lo?

O real, é para além do sonho que temos que procurá-lo - no que o sonho revestiu, envelopou, nos escondeu, por trás da falta de representação, da qual lá só existe um lugar-tenente. Lá está o real que comanda, mais do que qualquer outra coisa, nossas atividades, e é a psicanálise que o designa para nós" (Lacan, 1964/1998, p. 61).

Lacan afirma estar o real está no cerne da experiência analítica, uma vez que a delimitação freudiana de trauma tem sua origem neste campo. O real é o furo, o buraco 
e o lugar da falta, fundamento da divisão subjetiva. A entrada do sujeito no simbólico, no campo do desejo, implica o trauma a partir do qual se funda a realidade psíquica regida pela fantasia, que é a construção do sujeito para dar sentido ao que o trauma veio evidenciar: que a falta é inerente ao humano. Freud se ocupa da fantasia, interessa-se por sua função de adornar, de cobrir, e questionando sobre o que se encontra por trás do véu da fantasia, depara-se com o real.

Esse real que sempre escapa é o que nós convocamos aqui pelo que acreditamos ser sua marca, o fato de não haver representação possível para ele. Do registro do real retiramos a noção de irrepresentável como o ponto relacionado de forma estreita com o feminino. A experiência traumática, por meio do efeito de divisão psíquica, fragmenta a potencialidade representativa, confrontando o aparelho psíquico com o irrepresentável. É por haver sempre algo que nunca se entrega à representação, que o real faz girar em torno de si os outros dois registros: o imaginário, a construir fabulações, e o simbólico, a encadeá-las e desencadeá-las, sempre em relação a esse ponto irrepresentável, impossível de dizer.

A noção de real, tal como Lacan a definiu, está no centro do encontro do sujeito com a linguagem, a partir do qual fica marcado no sujeito um impossível, algo que não cabe numa palavra ou numa imagem, restando na forma de furo, de buraco. "É a própria linguagem que é castradora”, afirma Miller (1997, p. 461), pois o fato de falar - de ser e de viver na palavra - implica uma perda de gozo, substância que está situada no vazio do real, mais além do princípio simbólico que delimita o prazer. Ao parcializar esse gozo do momento mítico do ser uno, a linguagem desenha o limite fálico, situando-o como campo do desejo, no qual é possível usufruir de um gozo que, estando inscrito num sistema simbólico, impele o sujeito a movimentar-se nos laços com o outro. 
Entretanto, há uma parte do gozo impossível de ser simbolizada, que se impõe na hiância entre o desejado e o obtido, afirmando a força do real na economia psíquica e, portanto, no trabalho analítico, o que faz Lacan (1964/1998) afirmar que "nenhuma práxis, mais do que a análise, é orientada para aquilo que, no coração da experiência, é o núcleo real" (p. 55). A vertente real do gozo está localizada em uma parte do Outro que é inassimilável, que não se representa para o sujeito. Essa parte constitui o núcleo central do inconsciente "e é precisamente em torno desse núcleo real, esse buraco, que o inconsciente se estrutura, no simbólico, como uma linguagem” (Jorge, 2008, p. 53).

Como vimos, o núcleo do inconsciente é constituído por essa falta originária de objeto e é em torno desse furo que o inconsciente se estrutura enquanto linguagem. Tem-se assim designados dois aspectos diversos do inconsciente: um real, o furo; o outro simbólico, a linguagem; ambos os aspectos estão intimamente articulados (Jorge, 2008, p. 142).

Dessa articulação entre o simbólico e o real, entre a representação e o irrepresentável, destacamos duas noções essenciais à discussão proposta por este trabalho de tese: o significante e a letra. Em termos de linguagem, elas aparecem como articuladoras da subjetividade na fala e na escrita, sendo, assim, fundamentais à experiência analítica. Em relação à primeira, o significante, Lacan situa a possibilidade de articulação, do saber inconsciente, pela palavra. Quanto à segunda, situa o trabalho na borda do real como uma possibilidade de articular o gozo do ser, o que só pode ser feito por meio de um contorno no trabalho com a letra. Assim, indica ser na articulação entre o significante e a letra que se desdobra o trabalho com o inconsciente na experiência clínica psicanalítica. 


\subsection{O Significante e a Letra}

O ensino de Lacan passa por desdobramento e traremos a discussão do que acontece em dois momentos distintos desse ensino: o primeiro concernente ao Lacan do significante, isto é, do simbólico; e o segundo, ao Lacan da letra, do real. 4No primeiro, ele se debruça sobre o inconsciente estruturado enquanto linguagem, em que o significante se movimenta em torno da falta estrutural como uma forma de significá-la, de incluí-la no campo do sentido.

No segundo, Lacan se debruça sobre o inconsciente real, o furo no simbólico, a falta de um significante no campo do Outro. Em outras palavras, há um impossível que impõe um limite ao sentido, portanto, à significação e à palavra. Há um ponto não recoberto pelo significante, impossível de dizer e de se articular simbolicamente: um irrepresentável.

A linguagem articulada em um código, tal como é a linguagem humana, estabelece uma forma de constituição particular. O ser falante se constitui em um universo no qual a palavra vai costurando o corpo pulsante, vai atribuindo ao gozo uma consistência simbólica, vai representando os encontros do sujeito com o outro, as faltas, o sofrimento. O simbólico é, portanto, marca fundamental do humano, é o campo do Outro, o tesouro de significantes, a partir do qual o sujeito irá orientar-se e constituir-se.

É bem evidente que as coisas do mundo humano são coisas de um universo estruturado em palavras, que a linguagem, que os processos simbólicos dominam, governam tudo. Quando nos esforçamos em sondar no limite entre o mundo animal e o mundo humano aparece - e esse fenômeno não pode deixar de ser para nós um motivo de espanto - o quanto o processo simbólico como tal é inoperante no mundo animal (Lacan, 1959-1960/2008, p. 59). 
No Seminário 1, Os escritos técnicos de Freud, Lacan (1953-1954/1996) coloca em termos teóricos o entrelaçamento entre corpo e linguagem no que diz respeito ao ser humano. O processo simbólico lhe é inerente, sendo em torno das palavras que giram as relações humanas na cultura, isto é, no âmbito social. Em torno das palavras giram também as nomeações do início da vida, tão caras à estruturação psíquica e à subjetividade. Sobre a palavra humana, Lacan a distingue do grunhido animal pela forma de convocação ao outro com que ela se movimenta. No humano, sua estruturação exige o Outro, o campo simbólico que se manifesta na palavra do outro, ou seja, no reconhecimento. É preciso que esta palavra se faça crer, que haja um outro que a indague e se interesse por ela.

A noção de grande, Outro Lacan define como o lugar do qual pode ser colocada para o sujeito a questão da sua existência; é o campo da linguagem - portanto, do simbólico e do código social -, um campo que antecede o sujeito e que, ao mesmo tempo, opera sobre ele e sobre sua constituição; é, também, o lugar no qual é fundado o recalque como forma de o sujeito lidar com a falta na sua relação com a lei, elevando o objeto ao estatuto de símbolo e, por isso, permitindo ao sujeito a entrada na ordem da palavra.

Como vimos no capítulo anterior, o campo do Outro é encarnado primeiramente pela mãe que, ao interpretar o grito do bebê como um apelo, o transforma em significante e, assim, o insere em uma cadeia de linguagem, atribuindo-lhe um sentido. A linguagem fura o gozo pulsional, evidenciando uma falta, ou seja, instaurando um lugar vazio a ser buscado incessantemente pelo sujeito. A esse respeito, Lacan afirma passar o ser humano por dois nascimentos: o do organismo e o da entrada do sujeito no simbólico. Este último marca o momento em que os significantes se organizam em uma 
cadeia singular, que vai sendo representada subjetivamente no psiquismo do sujeito (Chatelard, 2005).

A entrada do sujeito no simbólico, como vimos no tópico anterior, é efeito da operação simbólica da castração, mediada pelo Nome-do-Pai que incide no lugar do Outro, ocupado pelo Desejo-da-Mãe. Esta operação parcializa o gozo em gozo fálico, inserindo o sujeito em uma cadeia de desejo. Nessa cadeia irão deslizar os significantes, presentes no campo do Outro e que passam a constituir o inconsciente do sujeito. Esse momento é marca de um encontro traumatizante do sujeito com a linguagem por encontrar lá um ponto irrepresentável, não simbolizável - real.

A noção de significante é crucial no ensino de Lacan. Ele vai buscá-la na linguística saussuriana com o intuito, na psicanálise, de retomar aquilo que acreditava estar no cerne do ensino empreendido por Freud. Lacan diz que a linguística, campo desenvolvido depois de Freud, o permitiu articular de forma mais clara o princípio sobre o qual a psicanálise foi fundada - a associação livre. Com as construções linguísticas sobre o sistema da língua, foi possível esclarecer que um significante é imagem, sonoridade e letra e que, ao se articular a outro significante, gera uma significação. Por isso, as construções discursivas são tomadas como sentenças lógicas que se articulam umas às outras por meio de relações de união, de substituição, de deslocamento e de apagamento - é a movimentação dos significantes que passa a criar diversas significações.

Lacan retoma a elaboração de Freud sobre os sonhos, apontando a relação entre inconsciente e linguagem. Influenciado pelo estruturalismo francês, formaliza a experiência analítica como uma experiência de linguagem, na qual tudo acontece no plano da palavra. Para tanto, Lacan recorre à linguística estrutural saussuriana e retira, 
da ideia de signo linguístico, o significante como o material constituinte da palavra que acessa $\mathrm{o}$ inconsciente.

No sistema da língua descrito por Saussure (1972), a palavra, por ele chamada de signo, é formada pela união entre o significante (imagem acústica) e o significado (conceito), o que acontece por meio de uma barra. Para Lacan, a barra diz sempre de uma separação e o significante está no comando, na parte de cima da barra, enquanto a cadeia de significado movimenta-se na parte de baixo da barra, fazendo com que diversos significados possam ligar-se a um mesmo significante, o que, de alguma maneira, justifica a força da associação livre.

O que faz um significante se ligar a outro, produzindo uma significação? Para Saussure, a ligação entre significante e significando obedece ao princípio da arbitrariedade. Em outras palavras, o que une um significante e um significado é uma força arbitrária, ou seja, não há uma explicação pela via da significância. Para Lacan, esse é o mistério do ser falante e, nesse aspecto, utiliza-se do significante para descrever a estrutura do inconsciente, apontando o sujeito do inconsciente no comando da cadeia da fala.

O significante, para Lacan, não está a serviço do significado, ao contrário, há algo no significante que o significado não alcança. Assim, diferentes significantes podem ligar-se a outros produzindo diferentes significados. É o sujeito quem faz o corte, no momento da fala, e o significante só passa para o plano das significações porque há um sujeito nesta cadeia. Um significante, portanto, evoca um significado que é particular de cada sujeito, uma significação produzida a partir das associações significantes feitas pelo sujeito falante.

A separação entre significante e significado marca a singularidade do sujeito, uma vez que o significante - palavra que permite o acesso ao inconsciente - isolado da 
cadeia, não remete a nada, é em si mesmo sem significação própria, pois o sentido é dado na articulação da cadeia que se acontece no ato da fala. É no deslizamento da cadeia, no intervalo entre um significante e outro, que aparece o sujeito. Quando fala, quando há encadeamento de significantes, o sujeito se divide, pois, ao mesmo tempo em que fala, é surpreendido pelo que diz - é falado por alguma formação inconsciente que aparece e desaparece quebrando a linearidade da cadeia da fala. A cada vez que isso acontece na passagem de um significante a outro, é possível que aí se produza um sujeito como efeito do significante que o causou (Sobral, 2008).

Se para Lacan um significante é o que representa o sujeito para outro significante, isso se dá na medida em que um significante não apresenta, isoladamente, poder de representação do sujeito e requer continuamente a remissão a outro significante. Para Lacan, o significante é, de saída, binário, par, parelha e o sujeito emerge enquanto intervalar, lugar de escansão entre-dois significantes (Jorge, 2008, p. 105).

Jorge (2008) enfatiza ser nas palavras enunciadas pelo sujeito, no próprio domínio da linguagem, que o inconsciente se encontra profundamente enraizado, pois "o inconsciente é, em seu fundo, estruturado, tramado, encadeado, tecido de linguagem" (Lacan, 1955-1956/2002, p. 139). A especificidade desta linguagem é o fato de nela o significante operar um papel fundamental, pois seu movimento vai conferir dinâmica ao inconsciente, produzindo, seja por deslizamento ou por substituição, “um jogo por meio do qual ele acabará por significar coisas bem diversas" (Lacan, 1955-1956/2002, p. 193).

Assim, a palavra no inconsciente "apresenta sempre a duplicidade essencial do significante e do significado. Isso quer dizer que o significante tem aí sua coerência e seu caráter próprios" (Lacan, 1955-1956/2002, p. 192). E, ainda, que "esse caráter do 
significante marca de maneira essencial tudo o que é da ordem do inconsciente" (p. 193). Para Lacan, a obra de Freud é impensável "se não se coloca no primeiro plano a dominância do significante nos fenômenos analíticos” (p. 193).

No Lacan da linguagem, surge uma orientação de seu ensino para o real. Chatelard (2005) afirma partir, o autor, de um sujeito representado pelo significante, na cadeia da linguagem, para chegar ao ser, naquilo que é, em sua essência, inapreensível ao significante: onde o significante tenta representá-lo ele escapa, fazendo o sujeito passar a deslizar pelos significantes em busca sempre de outro significante que possa dizê-lo.

Lacan (1957/1998) convoca, então, a noção de letra como suporte material, tomado de empréstimo da linguagem, pelo discurso, e explica o título do seu texto, $A$ instância da letra no inconsciente ou a razão desde Freud, referente ao fato de que "para-além da fala, é toda a estrutura de linguagem que a experiência analítica descobre no inconsciente" (p. 498). Nesse texto, ele afirma tratar, a obra de Freud sobre a interpretação dos sonhos, da letra no discurso, aquela que é a via régia do inconsciente.

Em Lituraterra, Lacan (1971/2003) apresenta uma distinção entre a letra, situada do campo do real, e o significante, no campo do simbólico. Ao recorrer à linguística saussuriana, o autor destaca o caráter de pura diferença como próprio do significante. Depois, ele torna as coisas um pouco mais complexas e convoca a noção de letra para falar do significante e faz uma distinção afirmando ser, o significante, pura diferença, enquanto a letra é idêntica a ela mesma, sua função é preencher o espaço da pura diferença. A letra é aquilo que cai do inconsciente em suas manifestações, marcando a presença do gozo no saber inconsciente. 
É, portanto, uma borda entre o saber e o gozo. Ela vem marcar o lugar que no significante faz retorno, a parte da fala que escapa ao sentido, pois o que ela porta é o traço de resistência do gozo ao saber, situando-se, assim, no litoral que separa o simbólico do real. Resta saber como o inconsciente, com sua estrutura de linguagem, comanda essa função da letra, função de furo na linguagem.

É neste ponto que abordamos a vertente real do inconsciente, no qual a ênfase recai sobre a categoria do impossível, da falta estrutural de um significante, de um ponto que impõe um limite à interpretação, justamente por ser o furo na linguagem, o furo na produção de sentido. O irrepresentável é marca desse lugar, é a evidência de nem tudo poder ser colocado em palavras por estar a questão do ser localizada em um impossível de dizer, o que provoca um retorno: por não ser possível dizer do ser de forma finda, é possível dizê-lo de forma infinita. O impossível de dizer fomenta o dizer.

Portanto, o humano se caracteriza por ser essa incompletude fundamental, essa divisão sempre presente entre corpo e linguagem, não havendo possibilidade de união harmônica entre os dois. Então, não havendo um significante para definir o ser, é preciso fazer engendrar, na experiência analítica, a leitura da letra, isto é, a escrita na palavra - aquilo que só se apresenta na forma de um apagamento, de uma fissura na linguagem ou de um buraco no sentido.

Seguimos Lacan (1971/2003), afirmando ser o sujeito dividido pela linguagem e, dessa forma, "um de seus registros pode satisfazer-se com a referência à escrita, e o outro, à fala" (Lacan, 1971/2003, p. 24). A fala é um encadeamento de significantes que, por sua movimentação e seu caráter simbólico, constituem um saber. A escrita é um trabalho com a letra, naquilo que ela pode simbolizar alguns efeitos do significante, aqueles que dizem respeito ao furo no saber, pois trabalha no campo do gozo e, principalmente, por esse campo estar no registro do real. "Representar por letras o 
irrepresentável, a escrita, as letras podendo ser equivalentes ao próprio real, este que não cessa de se escrever" (Chatelard, 2005, p. 182) é o que procuramos desenvolver no tópico seguinte por meio da função da fala e da escrita na subjetividade humana, principalmente na experiência analítica.

Como convocar, ou, como trabalhar com a letra na experiência analítica? O que é específico da leitura do psicanalista no texto do analisando? Como a fala e a escrita articulam as questões do inconsciente no percurso de uma análise?

\subsection{A Fala e a Escrita}

O humano, na condição de um ser de linguagem, está ancorado na palavra e na relação com ela circula em duas ordens: a fala e a escrita. Baseamos a delimitação da fala e da escrita, na teorização feita por Lacan sobre estes campos, ressaltando a sua importância, seja na vida cotidiana do sujeito, seja na experiência analítica.

No Seminário 18, De um discurso que não fosse semblante, Lacan (1971/2009) discute a relação entre a fala e o escrito, afirmando haver entre eles um ponto de articulação e um ponto de limite. No começo está a fala e a partir dela se abre caminho para o escrito que, de alguma maneira, repercute na fala, pois o escrito é algo de que é possível falar.

“Quer se pretenda agente de cura, de formação ou de sondagem, a psicanálise dispõe de apenas um meio: a fala do paciente" (Lacan, 1953/1998, p. 248). A fala é o modo pelo qual o sujeito se apresenta ao outro, estabelece laços e é, também (ou por isso), instrumento, veículo de acesso ao inconsciente na experiência analítica. É sobre a fala que o psicanalista intervém, convocando um engajamento do sujeito em seu dizer para introduzi-lo na fala analítica, na qual são permitidos, e até convidados, os atos falhos, os atos do sujeito no que tange o seu desejo e o seu gozo. 
Se a intervenção do psicanalista na fala do analisando produz efeito, isso se deve à transferência e ao fato de toda fala pedir uma resposta. Não há fala sem resposta, afirma Lacan (1953/1998), “mesmo que depare apenas com o silêncio, desde que ela tenha um ouvinte" (p. 249), é esse o cerne da função da fala na experiência analítica. O autor adverte não poder, o psicanalista, negligenciar a função da fala, seja o vazio que nela se faz ouvir inicialmente, seja o apelo à verdade que se faz ouvir a partir do engajamento do sujeito na fala analítica. Se o psicanalista o faz, isto é, se ignora a função da fala, ele passa a analisar o comportamento do sujeito como forma de preencher o silencioso vazio procurando encontrar o que o sujeito não diz.

Esse modo de intervenção desdobra-se na contramão da clínica fundada por Freud, pois, de acordo com a psicanálise delimitada por este autor, o sujeito vai ao analista para falar, desencadear, encadear novamente, associar, repetir, criar, entre outros, e é a escuta do analista, sua pontuação clamando por uma interlocução que se torna a base da experiência analítica e, assim, a fala do analisando passa a incluir a resposta do analista. Portanto, ao fundar a psicanálise como campo do inconsciente, Freud desvendou a estrutura de linguagem presente no saber inconsciente, um saber não-sabido pelo sujeito e oriundo de sua divisão subjetiva.

“A fala sempre ultrapassa o falante, o falante é um falado" (Lacan, 1971/2009, p. 73), pois o ser humano padece da fala. Ele é dividido entre o que fala e o que quer dizer, demonstrando a força do inconsciente, que traz à tona a subversão, na fala, da cadeia de linguagem, quando se presta a expressar o desejo do sujeito ou quando denuncia seu mecanismo de gozo. Isso ocorre pois, na cadeia da fala, o significante está no comando e, por vezes, antecede o sujeito, enunciando algo que lhe soa estranho. As formações do inconsciente estão aí para comprovar, para evidenciar a fala como campo do improviso, 
da sonoridade, da lalação, onde o estranho pode se apresentar e, por meio dele, apresentar algo totalmente novo ao sujeito.

Com a descoberta do inconsciente, Freud funda o método da associação livre como técnica da psicanálise, evidenciando ser no ato da fala, na cadeia da linguagem falada, que se abre a possibilidade de ver emergir o inconsciente e, com ele, uma verdade, única e singular. O tratamento por intermédio da fala veio marcar a fundação da psicanálise e fez Freud, posteriormente Lacan, se debruçar nessa ligação do homem com a linguagem. Em seu percurso a partir do encontro com as histéricas, Freud apontou o sintoma como denunciador do ponto de conjunção entre corpo e linguagem e, portanto, a ligação fundamental do corpo com o universo das palavras.

As histéricas, o que falavam elas? Em Função e campo da fala e da linguagem, Lacan (1953/1998) afirma que o que aparece na fala da histérica que salta aos olhos de Freud, "é que ela nos apresenta o nascimento da verdade na fala" (p. 257). Lacan enfatiza não estar a verdade, para Freud, na realidade vivida. Ela vem à tona no instante no qual, no ato de fala, aquilo que foi vivido passa a ser atualizado, reordenado na fala com vistas a um por vir. "É justamente essa assunção de sua história pelo sujeito, no que ela é constituída pela fala endereçada ao outro, que serve de fundamento ao novo método a que Freud deu o nome de psicanálise” (p. 258).

O inconsciente, segundo Lacan (1953/1998), é o capítulo da história do sujeito “marcado por um branco ou ocupado por uma mentira: é o capítulo censurado" (p. 260). A verdade, nele residida, só pode ser resgatada por meio da fala e, na maioria das vezes, já está escrita, pois a fala define o lugar daquilo que chamamos verdade, somente ela pode fazer surgir uma parcela da experiência vivida ou dos poderes do passado. A escrita, na qual está apoiada a verdade, se mostra como marca, em algumas instâncias da vida do sujeito, quais sejam: no corpo, cujo sintoma denuncia a estrutura de uma 
linguagem e é decifrado como uma inscrição; nas lembranças mais impenetráveis da infância; na evolução do vocabulário semântico; nas tradições que veiculam sua história; enfim, nos vestígios que conservam as distorções exigidas pela entrada em cena do capítulo censurado que é o inconsciente.

Essas distorções incidem sobre a cadeia de linguagem presente no consciente e nomeada por Lacan de discurso. Ele o situa como movimento da consciência regido pelo princípio de realidade, o qual, consciente ou pré-consciente, apresenta-se na ordem do discurso refletido, articulável e acessível (Lacan, 1959-1960/2008). Sendo da ordem do $e u$, o discurso é o modo pelo qual um indivíduo se dirige ao outro, apoiado na imagem de si - fundamentada prioritariamente no registro imaginário, um terreno que se apresenta como familiar por carregar dizeres que participaram da formação do sujeito e que o definem enquanto um ser social, no trabalho, na família.

Na experiência analítica, o sujeito chega com seu discurso, narrando ao analista um saber sobre ele mesmo: eu sou isso, eu gosto daquilo. Esse é o caminho pelo qual o sujeito se define, se situa em relação ao outro e vai representar, mesmo que não comunique nada, a existência da comunicação ou da possibilidade de uma interlocução - quando é possível fazer nele uma pontuação, uma subversão ou um deslocamento -, pois funciona como uma vestimenta da fala e é, portanto, o campo do qual nasce a fala analítica.

Lacan (1955-1956/2002) afirma que o fato de ter, a comunicação analítica, a estrutura de linguagem não significa exprimir-se, no discurso, o inconsciente. Quanto a este, conclui o autor: "eu nunca disse que é um discurso - mas estruturado como uma linguagem" (Lacan, 1955-1956/2002, p. 191) e, por esse motivo, o inconsciente evidencia a mais reveladora das relações do homem com o domínio da linguagem. 
Ao propor o inconsciente estruturado como uma linguagem, Lacan enfatiza ser, além da fala, a instância da letra o que enoda o ponto crucial e evidencia o que se passa no inconsciente. Miller (2012) afirma que para além da fala como desfilamento de significantes - no qual o significante associa-se a outros significantes de maneiras tão diversas de sujeito a sujeito -, a instância da letra descortina o fundamental na fala analítica: a escritura presente na própria fala.

No Seminário 7, A ética da psicanálise, Lacan (1959-1960/2008) enfatiza que a ideia de estruturação psíquica, delimitada por Freud, propõe marcações no sujeito sob a forma de inscrições. Uma primeira inscrição se dá sob a forma de uma escrita, a qual, de forma brusca, imprime no sujeito algo do mundo exterior. A partir daí, uma primeira memória é formada como um primeiro traço, "uma escrita, uma letra no ser do sujeito" (Chatelard, 2005, p. 107).

Ao afirmar ser o inconsciente aquilo o que se lê, Lacan (1972-1973/1985) destaca nele a letra como escritura localizada do significante, seu termo literal. Segundo ele, a letra presentifica o que descola o significante do significado, restando o significante despojado de qualquer valor de significação e localizado na materialidade. Devido a essa articulação entre a letra e o significante, entende-se, segundo Miller (2012), que já há na fala o equivalente a certa escritura. Miller traça um paralelo, entre a fala e o escrito, e afirma que Lacan atribui ao escrito um estatuto distinto de significado. No sentido deste autor, há no escrito algo mais ou algo distinto do significante e, assim, o escrito não se presta à leitura, está fora do que se diz e se lê.

No Seminário 18, De um discurso que não fosse semblante, Lacan (1971/2009) questiona qual é a função do escrito. Afirma, primeiramente, que no positivismo lógico o texto precisa ter um sentido apreensível e que isso é uma maneira de podar as coisas, como se uma coisa que não tem sentido não pudesse ser essencial no desenvolvimento 
de um discurso. "É exatamente na medida em que a referência quanto a tudo o que é linguagem é sempre indireta que a linguagem adquire sua importância” (p. 54). Se o discurso fosse sempre direto e com tendência à apreensão do sentido, não poderíamos nos servir do discurso matemático, por exemplo, caracterizado pelo fato de não podermos dar-lhe um sentido.

Segundo Lacan, esse é um ponto relevante no tocante à função do escrito e sua diferença em relação à fala. $\mathrm{O}$ escrito é matemático, não se presta ao sentido. Por se tratar da lógica, está em jogo, na matemática, a função de contagem que a letra, como caractere despojado de sentido, faz entrar em ação.

A letra é o suporte material da escrita, ela porta a singularidade radical do sujeito, seu traço de gozo. Uma marca real despojada de sentido que limita a cadeia significante, apontando a impossibilidade do sujeito se representar todo pelo significante. Nela está inscrita a forma de gozar de cada sujeito, a marca que insiste em suas repetições. Lacan a situa como litoral, a separar territórios distintos. Em outras palavras, como aquilo que do simbólico constitui a borda que avança sobre o real.

No livro Estou falando com as paredes, Lacan (1971-1972/2011) enfatiza o real, destacando a resistência de um ponto que não se entrega à decifração, e afirma viver, o ser falante, articulado no simbólico, mas não-todo, uma vez que o real está sempre ali a espreitar, a mostrar a insuficiência da linguagem no esforço que faz para dizê-lo.

No não-todo situamos o irrepresentável, esse recheio do real, inscrito no campo do gozo sem nenhuma significação que o abarque - nenhum significante que o represente - e que, justamente por seu vazio de significação, produz significância, fazendo girar em sua borda todos os significantes que se movimentam numa cadeia de linguagem na tentativa de dizê-lo, fazendo-o, sempre, não-todo. A parte dizível, ou simbólica, se desdobra na fala, pelo desfilamento de significantes; a outra parte, a 
indizível, ou real, há que se recorrer à escrita e aos trabalhos da letra em seu domínio, para termos alguma forma de acesso a ela.

No texto A função do escrito, no Seminário Mais, ainda, Lacan (19721973/1985) afirma que é preciso encontrar a função do escrito no discurso analítico e, se na experiência analítica "trata-se de saber o quê, num discurso, se produz por efeito da escrita" (p. 47), trata-se de buscar a letra.

No documentário Um encontro com Lacan, de Gerard Miller (2011), no depoimento de uma analisanda de Lacan, Suzanne Hommel, sobre uma intervenção feita por ele, destacamos a orientação para o escrito e para o trabalho com a letra enquanto guia do trabalho clínico. Hommel lhe conta de um sonho que tem e que a faz despertar às cinco horas da manhã, mesma hora em que a Gestapo vinha procurar os judeus em suas casas. Ela fala do insuportável dessa experiência quando, de súbito, Lacan se levanta e faz um gesto delicado em seu rosto: Geste à peau, ela o pronuncia no documentário, fazendo saltar aos ouvidos a homofonia.

Hommel afirma que naquele instante o significante Gestapo - associado a algo impossível de ganhar representação no plano simbólico pela linguagem - foi furado pela intervenção de Lacan, atingindo seu corpo na forma de um carinho no rosto. Temos aqui uma intervenção que ressoa no corpo-a-corpo apoiado naquilo que da palavra só se tem acesso pela consequência, pelo efeito que dela se destaca como letra, pois a letra é o traço entre o saber e o gozo. Há uma experiência de gozo pelo sujeito quando se rompe com o semblante (o significante), quando se faz furo no saber com o trabalho da letra.

Ao fazer um gesto delicado em seu rosto - Geste à peau - Lacan insere uma intervenção no nível do irrepresentável? Suzanne Hommel afirma que a conjunção do gesto feito por Lacan com o nome da Polícia Secreta do Estado não apagou as marcas 
que a Gestapo deixou, nem diminuiu a memória dolorosa daqueles dias. Entretanto o Geste à peau imprimiu algo completamente novo e singular.

$\mathrm{Na}$ experiência analítica, portanto, é preciso tomar a fala de maneira diferente. "E é formidável ter isso em Lacan. Saber como apreender a fala captada, torcida, quando não se trata de perguntas e respostas, mas sim essencialmente de sua relação com o gozo" (Miller, 2012, p. 21), pois o que garante à fala sua dimensão de verdade é a relação com o gozo, que se torna articulável numa estrutura de linguagem. O que faz Lacan (1971-1972/2011) afirmar que "não há interpretação que não se refira à ligação entre aquilo que se manifesta da fala, no que vocês escutam, e o gozo" (Lacan, 19711972/2011, p. 26).

O gozo tem o real como seu campo. Para acessá-lo, a interpretação visa a buscar o suporte na palavra, fazendo dela aparelho de gozo, pois "a verdade em questão na psicanálise é aquilo que, por meio da linguagem, quer dizer, pela função da fala, aproxima-se do real" (Lacan, 1971/2011, p. 56). O que faz Miller (2012) sugerir que, no lugar da fala como comunicação, se imponha uma fala como jaculação, cujo suporte é a letra, que não é do mesmo registro que o significante.

Na experiência analítica, portanto, é preciso buscar a escrita na palavra falada, pois nela está a marca da verdade de gozo de cada sujeito, verdade essa que só pode ser interrogada a partir do escrito. Na fala analítica o que se escuta não é o significado, é o significante, "se há alguma coisa que possa nos introduzir na dimensão da escrita como tal, é nos apercebermos de que o significado não tem nada a ver com os ouvidos, mas somente com a leitura, com a leitura do que se ouve de significante" (Lacan, 19721973/1985, p. 47).

A escrita consegue articular o real e o gozo, questão importante para este trabalho de tese interessado na forma como o irrepresentável pode ser abordado na 
clínica, especificamente na clínica do feminino. Como vimos, o irrepresentável é o traço real e sua força reside na impossibilidade de simbolizá-lo, de representá-lo, estando presente somente pela letra, aquela que serve de fronteira entre o saber e o gozo.

O irrepresentável é da ordem do gozo naquilo que o falo não ordenou como desejo. É por isso que o feminino articula-se a ele, uma vez que o falo não é suficiente quando se trata da inscrição simbólica do feminino. Não havendo, no campo do Outro, um significante que represente a mulher, a escrita, por meio do trabalho com os contornos da letra, pode servir de suplência a essa falta estrutural da linguagem?

Ao dizer que falta o significante do feminino no campo do Outro $S(A)$, Lacan atribui a esse campo uma dimensão de furo, de perda. O fato de não existir o significante da mulher no campo da linguagem - campo do Outro - produz, no lugar do furo, um gozo singular, que está fora da linguagem, sem inscrição. Esse gozo suplementar, nomeado por Lacan (1972-1973/1985) de gozo feminino, é um gozo sempre Outro e o faz sugerir que quando se trata do gozo feminino a escrita "mostrará ser uma suplência desse não-todo sobre o qual repousa o gozo da mulher” (p. 49), pois esse gozo Outro a faz "em algum lugar ausente de si mesma, ausente enquanto sujeito" (p. 49).

"É certo que, como de hábito, nisso a psicanálise tem algo a receber da literatura" (Lacan, 1971/2003, p. 17). Segundo Lacan (1971/2003), em Liturratera, a escrita literária porta uma estreiteza com o feminino. A escrita literária permite um estar fora de si e isso faz com que o narrador possa contar com o uso da invenção ao escrever um conto, um livro ou um poema. Por se tratar do literário, o escritor não está preocupado com a produção ou a sustentação de um saber. Em sua escrita, ele se julga “dispensado de dar mostras de qualquer saber" (p. 18), tirando da escrita outro partido. 
Álvares (2001) aproxima o literário e a escrita, afirmando ser, o literário, a coisa escrita. Segundo ela a coisa literária é aquilo que a literatura, enquanto linguagem, não converte em sentido, apoiando na noção de irrepresentável tal articulação. Ela situa o irrepresentável "como aquilo que da ou na linguagem lhe é estranho porque constitui obstáculo à sua função por excelência: a de ligar os homens através do discurso veiculando representações e significações” (p. 03).

De acordo com a autora, cabe à escrita literária o exercício de uma violência sobre a lei da linguagem, resultado do trabalho com o irrepresentável, pois o literário é o discurso do real, ele emerge de um encontro com o real, com sua violência e com seu vazio. "Esta violência só é possível graças à letra" (p. 08), pois a letra é a substância literária da linguagem, "resto indedutível, inconvertível, da forma do sentido: a letra é o que é impossível de traduzir" (p. 08).

Sobre a função do escrito e o trabalho no âmbito da letra, Lacan (19721973/1985) sugere a leitura de James Joyce para que se possa ver "como a linguagem se aperfeiçoa quando se trata de jogar com a escrita” (p. 51). Em Joyce, a escrita é um efeito de resposta ao real, uma produção que se dá em termos de gozo, o que faz com que o texto torne-se, pelo lado do significado enigmático e, pelo mesmo motivo, possa "ser lido de uma infinidade de maneiras diferentes" (p. 52).

\subsection{O Feminino e o Irrepresentável}

Lacan (1971-1972/2011), ao abordar a diferença dos sexos, destaca que homem e mulher são posições subjetivas assumidas pelo sujeito na linguagem. Em qualquer língua do mundo, tudo se designa por ele ou ela, é o princípio de funcionamento do gênero na linguagem. 
Vimos no capítulo anterior que por meio das fórmulas da sexuação Lacan articulou a posição masculina e a posição feminina. O lado homem se define todo pela função fálica, uma vez que houve ao menos um - o Pai, como exceção - que gozasse ilimitadamente e que, uma vez morto, fundou o conjunto dos homens cujo gozo sexual é possível, desde que limitado, inscrito no plano simbólico, articulado na linguagem.

O lado mulher se define como não-todo inscrito na lógica fálica. O não-todo é o indicativo lógico de não ter havido a exceção que sustentasse a representação da mulher toda na lógica fálica. Sua relação com o simbólico se dá de uma maneira particular, não-toda articulada por ele. Pois no simbólico - campo do Outro, da palavra - não há a inscrição de dois sexos - não há o segundo sexo -, a partir do momento em que a linguagem entra em função só há a inscrição do falo como única referência ao sexo.

Assim, um homem e uma mulher, para situarem-se em seu corpo, em uma imagem, em uma função, recorrem ao campo do Outro onde se situam entre alguns significantes que passam a representá-los. Esse é o campo simbólico onde o falo é o significante de referência e faz girar em torno dele muita coisa: identificações, enfeites, defesas, posições, entre outros. No encontro sexual entre um homem e uma mulher é a função fálica que está em cena fazendo com que um se dirija ao outro numa referência ao falo. O homem, todo inscrito no campo fálico e que encontra nele uma representação suficiente para sua função e seu gozo, toma a mulher como objeto causa do seu desejo. A mulher, não estando toda lá, oferece-se como objeto $a$, encarnando a função de ser o falo.

$\mathrm{Na}$ função fálica, o encontro sexual é subvertido pela linguagem, podendo encontrar alguma representação. Portanto, o ato sexual existe fazendo as funções homem e mulher funcionarem na cama, o que convoca o aforismo de Lacan, não há relação sexual, para esclarecer o que não há: a possibilidade de haver entre um homem 
e uma mulher uma proporção sexual, graças ao que o gozo sexual é possível. Não há proporção sexual uma vez que, no quadro, o lado homem e o lado mulher só dialogam por meio de um significante comum. Não há um significante da mulher que ensaie uma proporção com o falo. Isso leva Lacan a afirmar ser no âmbito do semblante que acontece o gozo sexual entre os seres falantes, no que ele não se satisfaz só com o sexo, passando necessariamente pelo significante. É, portanto, um gozo vinculado à linguagem.

Miller (1997), em Lacan Elucidado, afirma ser este o ponto no qual a descoberta de Freud mostra toda sua importância, por desnudar que o gozo sexual pode satisfazerse com o significante e por demonstrar, assim, a existência um gozo sexual vinculado ao falar. Isso remete à noção de sexualidade proposta por Freud a qual "tem como componente essencial que a sexualidade pode satisfazer-se com palavras, com o belo, com os valores mais altos da cultura” (p. 289). A prática analítica faz aí a sua entrada como um discurso que torna possível, pelo do trabalho com a palavra, aproximar-se do inconsciente.

Se não é na lógica fálica que se situa a diferença entre homem e mulher, pois na condição de ser falante ambos estão referidos ao falo, onde se localiza essa diferença? A diferença, afirma Dafunchio (2013), se encontra no lado mulher da questão, cuja forma de gozo é dividia: uma seta aponta para o falo e outra para a existência de um gozo para além do falo, um gozo propriamente feminino que não encontra representação na linguagem, estando ele mesmo numa estreita relação com o furo no simbólico, o buraco irrepresentável no campo do Outro, no qual o real faz sua morada. O que, nas fórmulas, é demonstrado com $\mathrm{S}(\mathbb{A})$, a barra apontando para a falta de um significante no campo do Outro. 
Nas fórmulas, vimos que é nesse lugar, no $\mathrm{S}(\mathbb{A})$, que reside o gozo feminino, suplementar. Esse gozo deriva justamente da falta de representação do feminino no campo do Outro, campo onde o sujeito se reconhece e se faz reconhecer (Lacan, 19551956/2002). Esse é o ponto de articulação entre o feminino e o irrepresentável, apontando que ali, no lugar topológico do irrepresentável que é o real, reside um gozo essencialmente feminino.

É numa relação estreita com o irrepresentável, portanto, que o feminino se estabelece, estando sempre não-todo recoberto pela significação, que por sua vez é sempre fálica. O ponto no feminino não inscrito simbolicamente resta enigmático, sendo na pura diferença que ele se impõe, não havendo, assim, referência nem generalização possível - a cada vez que ele se apresenta, é sempre Outro.

Segundo Dafunchio (2013), ao trazer para as fórmulas a questão da diferença entre os sexos, Lacan propõe, em cada lado do quadro, fórmulas que apresentam estruturas significantes do corpo, um aparelhamento do corpo pela linguagem e define a relação tanto do lado homem como do lado mulher com o gozo sexual a partir do corpo. Isso porque "o sujeito encontra seu lugar num aparelho simbólico pré-formado que instaura a lei na sexualidade. E essa lei não permite mais ao sujeito realizar sua sexualidade senão no plano simbólico. É o que quer dizer o Édipo" (Lacan, 19551956/2002, p. 195).

A lógica do Todo e da exceção é aplicada ao corpo do homem cujo "gozo corporal se constitui como um conjunto fechado na medida em que, no seu corpo, ele conta com um órgão que funciona como exceção ao conjunto dos órgãos corporais, o falo" (Dafunchio, 2013, p. 35), pois “o falo é um órgão que se destaca do corpo, que se eleva ao estatuto de significante" (p. 35). Essa construção evidencia como o pênis sai do registro puramente imaginário e ganha uma força simbólica, fálica, fazendo com que o 
gozo do órgão masculino encontre no significante uma possibilidade e também um limite, "limite que a castração impõe ao desejo do homem, à sexualidade masculina" (p. 36).

Marcos André Vieira (2013), no texto Mulher: figura impossível, comenta ser o homem sempre reconhecido pela regularidade do seu gozo - "sempre no mesmo lugar, seguindo as mesmas regras, as da castração" (p. 69). A identificação masculina sustentada por um Pai e pelo amor de uma mãe está apoiada em referências edípicas que imprimem ao gozo masculino um caráter de ser "sempre parcial e limitado, mas por isso mesmo, especialmente intenso, o que faz a glória e a miséria dos homens" (p. 69).

As mulheres, não tendo do pai a identidade, mas apenas o amor (nem de longe tão incondicional quanto o de uma mãe) serão bem menos localizadas por seu gozo. Ele ganha outro modo de presença - a ponto de Lacan chamá-lo: Outro gozo (Vieira, 2013, p. 69).

No corpo feminino, no lado mulher do quadro, não existe nenhum órgão que cumpra a função de exceção fundadora de uma inscrição psíquica do que é o feminino. Dafunchio (2013) explica que o fato de não haver a exceção faz o corpo feminino em seu gozo ser um conjunto aberto, o que estabelece como consequência um gozo sexual deslocado. "A vagina não é o órgão de gozo feminino" (p. 37). Lacan afirma que somente por uma conversão histérica uma mulher pode gozar de um órgão que fisiologicamente não tem com o que gozar.

Zalcberg (2007) segue a mesma linha, afirmando que a vagina pode ser bem conhecida como órgão, pedaço do corpo, mas não é conhecida no âmbito simbólico como sexo feminino. "A vagina não tem o mesmo valor como suporte imaginário para um possível representante do sexo feminino no inconsciente, assim como o pênis o é para o falo, este sim representante do sexo no inconsciente" (p. 28). O irrepresentável 
está no centro incógnito do feminino, ele é o lugar da falta de um significante no campo do Outro $S(\AA)$, para onde, nas fórmulas, está apontada a seta em direção ao Outro gozo.

As fórmulas da sexuação trazem a complexidade do gozo feminino, por meio de uma formulação lógica, e evidencia a ligação do feminino tanto com o gozo fálico, fomentado pela representação, isto é, pela palavra geradora de sentido simbólico, como também evidencia a ligação do feminino com Outro gozo, fomentando pelo irrepresentável, portanto, situado no real. O mistério que bordeja o gozo feminino, pelo fato de permanecer irrepresentável, ou seja, de não estar ao alcance da palavra, provoca a interrogação sobre o que é ser uma mulher tanto nas mulheres como nos homens e, ainda mais, nas crianças.

No Seminário 20, Lacan (1972-1973/1985) afirma que ao questionar as mulheres sobre o gozo feminino, elas nada diziam, o que o fez concluir ser um gozo que se experimenta, mas nada se sabe sobre ele. É um gozo que não encontra morada no saber, que não se articula na cadeia significante e que percorre o corpo inteiro, "ele estaria bem mais próximo do que seria o gozo como tal - da vida que em nós existe e insiste, mas que em si, não há como representar” (Vieira, 2013, p. 69).

Vieira (2013) localiza o feminino como "o sem figura do real" e alude à feminilidade como um trabalho diante das encarnações do irrepresentável, uma cobertura, uma veste para o irrepresentável, sem figura, do real. Vieira (2013) enfatiza, ainda, que as considerações de Lacan sobre o gozo feminino são, para analistas e analisantes, uma questão clínica, não somente uma teorização. Dela, parte a questão crucial para o trabalho analítico e, também, para nosso trabalho de tese: "Como dar destino ao real sem passar pelos poderes da representação?” (p. 70). Dito de outro modo: Como trabalhar clinicamente o irrepresentável? Quais as vias de escoamento desse Outro gozo? 
É de divisão da posição feminina que Lacan fala, deixando intacto o enigma que representa para o homem o gozo que ele supõe na mulher, gozo não discernível por ele, impossível de dizer por ela, gozo "outro", do qual certas místicas dão testemunho (Mannoni, 1999, p. 78).

Para falar desse gozo, Lacan alude à estátua de Santa Tereza D'Ávila para afirmar que, ainda que nada se fale dele, é evidente que há um gozo no corpo. Como dizê-lo? "Os místicos têm a experiência de um gozo sobre o qual não podem dizer, senão por meio da poesia. É um gozo que não consegue se transformar em saber" (Dafunchio, 2013, p. 38). A poesia mística aparece como uma forma de transmissão de uma experiência de gozo - um conjunto aberto que atravessa o corpo inteiro.

A experiência mística busca alcançar um gozo pelo do encontro com Deus. A renúncia às coisas mundanas aponta para a existência de Deus dentro do próprio sujeito, em um lugar irrepresentável, que foge ao alcance das palavras. Assim, os místicos buscam, por meio do silêncio, da meditação e da oração, acessar o Outro gozo encontrado além das palavras, no registro do real, um gozo mais próximo da experiência, e do sentir, e mais afastado do saber, da produção de sentido.

A saída mística, na busca pelo encontro com o irrepresentável, é seguir em busca de um lugar fora da simbolização - lugar de Deus. O gozo do místico ocorre justamente no ponto em que falta o significante no campo do Outro, ponto em que o sujeito não se sente representado, ponto de despojamento do eu, despojamento das vestimentas simbólicas, no qual a proximidade com o real convoca um tipo de êxtase, um gozo Outro.

Pommier (1987) indica a ligação entre a experiência mística e as mulheres pela incidência de um gozo Outro, próprio do feminino, um gozo que acontece por meio de uma experiência que escapa à linguagem e resiste à transmissão. "O élan místico é 
indizível porque se funda sob a falta de uma palavra que diria tudo" (p. 65), o Nome de Deus vem, então, ocupar o lugar desse indizível, desse irrepresentável não definido por outras palavras e que escapa às regras da linguagem. "Deus é assim o nome de empréstimo da ausência do Nome, recobre o furo dos símbolos linguajeiros, incapazes de se definir por si mesmo" (p. 65).

Onde não há definição possível sobre o ser, por se tratar do furo estrutural da linguagem, os místicos e as mulheres testemunham haver Outro gozo que se experimenta quando se aproxima do real. O real, morada do irrepresentável, é o registro do qual o sujeito se defende construindo amarrações simbólicas e fantasias. O caminho em direção ao Outro gozo depende da confrontação com a ilusão da completude promovida pela fantasia. O despertar da ilusão retira o sujeito da busca incessante pelo sentido, abrindo a possibilidade de um sentir no corpo, resultado da incidência do real, do qual nada se sabe a não ser que se experimenta.

Além da experiência mística, Lacan percebe na arte também uma forma de aproximação com o irrepresentável, afirmando que a produção do artista - do escritor criativo, para retomar o texto trabalhado por Freud - é desenvolvida em uma relação com o real. A obra, veiculadora ou não de sentidos simbólicos e imaginários, comporta o furo em sua estrutura e é a partir de um estreitamento com o real, impossível de dizer, que ela é criada.

Mannoni (1992) - ao trabalhar a relação entre psicanálise e poesia, em seu livro Um espanto tão intenso: a vergonha, o riso, a morte - afirma que a linguagem, o simbólico, é o campo pelo qual o artista veicula sua obra. No entanto, sua produção se encontra ao lado "daqueles que utilizam outros meios, que não a linguagem, para suas criações" (p. 30). A criação de uma obra, para Mannoni, está relacionada a uma espécie mais misteriosa de gozo, resultado de um encontro com a hiância, existente no ser 
falante, entre corpo e linguagem. O trabalho do artista se desdobra nessa hiância, nesse furo na linguagem, residência do irrepresentável.

Dessa forma, a arte se aproxima do feminino naquilo que dá testemunho de um gozo no lugar vazio de representação, não se tratando, em absoluto, de preencher esse vazio. Ao contrário, o movimento do artista, tanto quanto o da mística e o do feminino, acontece de modo a enaltecer o vazio pelo seu contorno. Uma invenção particular, um savoir-faire nos contornos do real e uma maneira de encontrar-se com o impossível. Essa experiência de gozo é despojada de qualquer estrutura de saber e, não sendo passível de delimitação, caminha em direção à verdade. 


\section{CAPÍTULO 3}

\section{Perspectivas Clínicas}

A terapia literária consiste em desarrumar a linguagem a ponto que ela expresse nossos mais fundos desejos. Manoel de Barros ${ }^{4}$

\footnotetext{
${ }^{4}$ Manoel de Barros (2008, p. 70).
} 


\subsection{Psicanálise, Ciência e Arte}

A única vantagem que um psicanalista tem o direito de tirar de sua posição, sendo-lhe esta reconhecida como tal, é a de se lembrar, com Freud, que em sua matéria o artista sempre o precede. Jacques Lacan ${ }^{5}$

Freud funda a psicanálise na fronteira entre a ciência e a arte. Apoiado no contexto cultural do final do século XIX, Freud parte de uma incerteza diagnóstica que se apresentava à comunidade médica da época, no tocante às manifestações histéricas, para desenvolver uma teoria sobre o psiquismo o humano. Essa teoria formaliza o inconsciente como uma instância subjetiva que move os sujeitos em suas relações com o desejo e com a cultura.

Nos textos Moral sexual civilizada e doença nervosa moderna (1908) e Malestar na civilização (1930), Freud descreve as transformações advindas da modernidade e suas implicações no psiquismo humano, localizando a modernidade como um momento cultural construído sobre uma repressão moral do sexual, e afirma que esse fato implica a formação das doenças nervosas. O saber cifrado, trazido pelos corpos histéricos, apontava para uma ligação, entre o somático, o psíquico e a cultura, carente de um método de intervenção clínica que a alcançasse.

Por seu cientificismo e por seu rigor inflexível em demonstrar a existência do inconsciente, a via aberta pela psicanálise levará para sempre o nome de Freud (Lacan (1965/1998). Nos escritos freudianos, podemos acompanhar as delimitações de conceitos, as construções teóricas, as advertências e as considerações sobre os procedimentos clínicos feitos pelo autor diante de uma comunidade científica que o questionava sobre a eficácia terapêutica da psicanálise e, ainda, sobre o respaldo

\footnotetext{
${ }^{5}$ Lacan (1965/2003, p. 200).
} 
científico de suas descobertas. No Projeto para uma psicologia cientifica, Freud (1950 [1985]/1987) busca desenvolver uma explicação para estas descobertas apoiada na neurologia, utilizando analogias entre o que acontecia no sistema nervoso e o que acontecia no psiquismo, como forma de enquadrar a psicanálise no âmbito das ciências modernas.

Embora por toda a teoria freudiana percorra o caráter cientifico da psicanálise, nos textos Interpretação dos sonhos (1900), Três ensaios sobre a teoria da sexualidade infantil (1905) e Introdução ao narcisismo (1914), bem como em seus textos posteriores, Freud estabelece outra via de interpretação para a psicanálise, uma via que explica a constituição do psiquismo humano, atrelando o inconsciente à representação simbólica da inscrição do sujeito na linguagem e na cultura pela palavra e, também, a uma teoria da pulsão, na qual o desejo encontra vias de escoamento ou de repressão.

Em seu texto A questão da análise leiga, Freud (1926/1987) discorre sobre a necessidade de autonomia da psicanálise em relação à medicina, justificando haver uma formação diferente para o psicanalista em relação à formação médica. Ao analista são necessários análise pessoal, estudo teórico e supervisão clínica e, acrescenta, o conhecimento sobre outras áreas, dentre elas a literatura. Lacan (1957/1998) adverte "que Freud sustentou com constância até seu fim a exigência primordial dessa qualificação para a formação dos analistas, e que apontou na universitas litterarum de sempre o lugar ideal para sua instituição" (p. 497).

O esforço freudiano de delimitar a psicanálise como um campo independente se justifica pelo fato de estar, a experiência psicanalítica, em outro mundo, com outros fenômenos e outras leis - as leis do inconsciente, ancoradas na fantasia e estruturadas como uma linguagem. Nesse momento, Freud convoca outro saber, um saber oculto para o sujeito e que se afasta do saber encadeado sobre sua história. Esse saber, 
inicialmente escrito no corpo das pacientes histéricas, não encontrava um lugar na ciência médica a não ser como enigma, como algo misterioso relacionado a um campo não submetido à mensuração e à objetividade propostas pela ciência positivista.

Lacan (1966/1998), no texto A ciência e a verdade, afirma ter, a psicanálise, nascido da ciência. Mannoni (1992) explica que a psicanálise não teria encontrado lugar no mundo pré-científico, "pois é o espírito cientifico o responsável pela eliminação da magia, do animismo, das diferentes mitologias e do irracional em geral, e somente nessa situação histórica podia a psicanálise nascer” (p. 160). A ciência positivista - apoiada na observação, e não mais na imaginação, e interessada por verdades absolutas apoiadas em dados positivos e concretos - possibilitou (e, talvez, possamos dizer que necessitou de) a intervenção psicanalítica como campo que se interessa em investigar o que se produz na fronteira entre a realidade interna (psiquismo) e a realidade externa (cultura/civilização) e, também, a relação disso com a produção de sintomas para os quais não encontravam resposta na ciência médica, da qual Freud fazia parte.

A não correspondência direta entre o que se passa no inconsciente e a história vivida das histéricas permitiu a Freud perceber que algo se forma quando cada sujeito, no traçado de sua história, começa a interpretar o mundo e as relações a sua volta. Esse é o momento em que Freud abandona a assertiva da experiência realmente vivida - de um abuso sexual por parte dos pais para com seus filhos na infância - para privilegiar a experiência tal como o paciente a imaginou. É, portanto, a verdade revelada na fantasia que interessa à psicanálise, mais propriamente a verdade que se produz no relato da fantasia, impressa na palavra da história contada, que, apesar de estar relacionada a algum fato da realidade vivida, traz como núcleo central os desejos inconscientes.

O inconsciente, delimitado por Freud, é formulado por Lacan como um espaço de saber sobre o sujeito no qual reside sua verdade. O saber que se aloja no inconsciente 
não encontra ressonância no saber cientifico - saber que produz uma verdade irrefutável e universal -, pois se refere a um saber que se encontra barrado para o sujeito, interditado por leis que estruturam a vida em sociedade e por tabus fundados em nome de um totem, como o incesto, censurado. Entretanto, este saber, do qual o sujeito nada sabe, recobre-se de outro, um saber discursivo, do qual o sujeito se apropria em formato de uma linguagem que o permita fazer laços com outros sujeitos, que o represente e que o comunique para o outro.

Freud apontou, como uma dificuldade da psicanálise, a maneira de fazer entrar em jogo essa função específica do saber, uma vez que a novidade revelada pela psicanálise traz à tona a divisão psíquica na qual há um eu que se apresenta como aquele que sabe e há o sujeito do inconsciente que evidencia a existência de um saber nãosabido por parte do próprio sujeito, enunciando, assim, que "se o inconsciente é algo de surpreendente, é porque esse saber é outra coisa” (Lacan, 1971-1972/2011, p. 23).

Lacan (1971-1972/2011) afirma estar, o aspecto fundamental da descoberta freudiana, no fato de o inconsciente evidenciar "uma subversão que se produz na função, na estrutura do saber" (p. 23), o que acarreta uma forma inteiramente nova de articular a linguagem da qual se desdobra o discurso analítico.

Magno (1977) afirma que o saber do inconsciente não pensa, não calcula, nem julga. Sua subversão reside no fato de ser um saber que se apresenta de forma cifrada e que, portanto, pode transcender o sentido - "e esta via é a única de qualquer comunicação na relação analítica" (p. 61). Esse saber, no entanto, se articula, é estruturado como uma linguagem e apresenta características próprias.

A linguagem é o ponto de ancoragem do ser falante. Não há nada no mundo humano que não seja articulado pela linguagem a não ser o real, é o que Lacan introduz a partir da delimitação feita por Freud sobre o inconsciente. O real é o campo 
responsável pelo ciframento do saber inconsciente, algo impossível de se apreender, impossível de ser representado, indizível, temido pela ciência que trabalha na tentativa de apreendê-lo e à qual o real sempre escapa. Uma brecha se abre e a psicanálise se desenvolve em um movimento contrário, interessando-se pelo real e imprimindo força ao que ele tem de irrepresentável (Lacan, 1966/1998).

A invenção freudiana, portanto, traz para a cena do mundo científico o interesse pela articulação do singular, produzindo-se na contramão do absolutismo cientifico que busca achar formulações universais sobre o homem e métodos cada vez mais exatos e generalizados de operar sobre ele. O singular, em psicanálise, é entendido como traço que identifica cada sujeito em sua particularidade por trazer em sua linha as marcas de sua constituição, a letra do seu nome. É nesse ponto que a psicanálise se interessa pela arte, considerando a maneira pela qual ela veicula, no universal, o singular, sem desfazê-lo, interessando-se pelo que se encontra por trás do dito, na entrelinha do dizer.

O encontro da psicanálise com a arte acontece ao longo das descobertas freudianas sobre o funcionamento do inconsciente e seus conteúdos, ao notar que o saber inconsciente que descobrira estava antecipado nas criações artísticas. "Freud nunca deixa de especificar que não inventou a psicanálise. Ela já existia nos grandes escritores. Ele só teve de resgatá-la" (Mannoni, 1992, p. 168). O saber artístico que interessa à psicanálise, desde Freud, diz respeito à criação poética e à linguagem. Em seu texto Delírios e sonhos na Gradiva de Jensen, Freud (1907 [1906]/1987) descreve com admiração como encontrou na obra literária de Jensen um eco, uma aproximação com a teoria que desenvolvia, aproximação que ele não encontrava na ciência médica, por se tratar de um saber que escapa à objetividade, que não pede nem se sustenta em cima de uma comprovação, não se quantifica nem se submete às expectativas científicas. 
Em Escritores criativos e devaneios, Freud (1908 [1907]/1987) aponta um saber criativo, capaz de despertar emoções das quais não nos julgamos capazes, e adianta que buscar uma explicação para a criação artística é um trabalho em vão, já que não é possível saber o que determina internamente as escolhas de um escritor. É o resultado do trabalho criativo - a obra em si, o que ela veicula em sua forma encobridora, não diretiva - que permite a interlocução entre a psicanálise e a arte.

Ao longo da sua obra, Freud recorre à produção artística no sentido mais geral do termo, interessando-se pelos diversos gêneros literários e discorrendo sobre seus mais variados aspectos: a criação, a sublimação, a encenação e o humor. Escritores criativos e devaneios (1908 [1907]), Personagens psicopáticos no palco (1905-1906), Delírios e sonhos na Gradiva de Jensen (1907 [1906]), O Humor (1927) e O Estranho (1919), entre outros, são textos que trazem o percurso e o interesse de Freud pela produção artística. A literatura é utilizada no curso da sua obra - seja em citações de trechos literários ou fragmentos poéticos, seja problematizando personagens, apontando sintomas e tecendo análises - como no ensaio sobre Leonardo da Vinci. Freud fez uso da literatura não "como um terreno onde aplicar suas teorias, mas em busca de uma verdade sobre o homem de que as obras literárias e artísticas se aproximariam mais do que a ciência” (Rivera, 2005, p. 65).

Há saberes impossíveis de serem mensuráveis, saberes obscuros, cujo rigor não se encontra no plano cartesiano da consciência, mas em outro lugar no qual a linguagem subverte a lógica científica. É o mundo da fantasia, dos sonhos, dos sintomas, dos atos falhos, dos chistes, assim como da arte, da literatura e da poesia, no qual o previsível se equivoca e assim convoca um sujeito que se põe em criação. Maurano (2010), a respeito do lugar da psicanálise "entre a ciência e a arte" (p. 8), sublinha a impotência do 
discurso científico quanto à subjetividade humana, apontando que no psiquismo habita o indizível, o atemporal, o irrepresentável.

A psicanálise, devo lembrar a título de preâmbulo, é uma disciplina que no conjunto das ciências se apresenta a nós com uma posição realmente particular. Costumam dizer que ela não é uma ciência propriamente dita, o que parece implicar por contraste que ela é simplesmente uma arte (Lacan, 1952/2008, p. $11)$.

Lacan (1952/2008), em O mito individual do neurótico, ou, poesia e verdade na neurose, ao aproximar a psicanálise da arte, mais que da ciência positivista, ressalta o caráter não objetivável da experiência analítica, uma experiência que comporta, no seio de si mesma, uma verdade que não pode ser dita por completo, pois o saber que a constitui é um saber inconsciente, não-sabido pelo sujeito, e sua verdade é definida pela fala, por isso imprevisível e singular. "A verdade é, finalmente, o encontro sempre faltoso com um real que não se consegue designar, no discurso, senão como ponto de umbigo, lacuna, representação faltosa" (André, 1994, p. 10).

É, portanto, na fronteira entre a verdade e o saber que Lacan situa o discurso analítico como uma linguagem que se interessa pelo ponto, na palavra, que serve de suporte do irrepresentável, que não o rechace em nome da comunicação ou de uma sintaxe organizada. A palavra que a psicanálise busca, na experiência analítica, encontra-se nos sonhos, chistes e atos falhos, uma palavra que, ao se prestar ao equívoco de seu sentido habitual, funda a dimensão da verdade no sujeito, apontando que "atrás do que diz um discurso, há o que quer dizer, e, atrás do que quer dizer, há ainda um outro querer dizer, e nada será nunca esgotado" (Lacan, 1953-1954/2009, p. 314).

Lacan enuncia um interesse especial pela poesia apontando o que permeia seu 
ensino: o sujeito como um efeito de linguagem em sua estrutura e em sua incompletude, ou seja, naquilo que é possível ser veiculado pela palavra - o significante - e naquilo que a estrutura simbólica da palavra não consegue abarcar, o real, a letra, o traço radical de um sujeito. Para ele, a poesia traz, em seus mecanismos de linguagem, formas semelhantes de articulação e de uso da palavra à função e à organização do significante e da letra no inconsciente.

Lacan aponta a poesia como via possível de interpretação na psicanálise por acreditar "nela como possibilidade de acesso ao real e no ato poético como matriz do trabalho analítico" (Julien, 2009, p. 51). No Seminário 24, L'insu que sait de l'une bévue s'aile à mourre, Lacan (1976/1977) afirma que a poesia é efeito de sentido, mas também efeito de furo e, por isso, traz à tona a especificidade da relação entre o significante e a letra, na qual localiza a questão da interpretação na clínica psicanalítica, uma vez que essa articulação toca no nó, no entrelaçamento entre o desejo e o gozo. O que nos faz propor, no tópico seguinte, a interlocução entre a interpretação na clínica psicanalítica e a poesia como via de trabalho com o inconsciente.

\subsection{A linguagem do inconsciente e a linguagem poética}

O que sustenta a encantação de um verso (além do ritmo) é o ilogismo. Manoel de Barros ${ }^{6}$

Uma criação de arte, um texto ou um poema é um relato subjetivo, uma ficção própria da natureza humana, um trabalho que se desenvolve em torno do vazio, do indizível, promovendo, em seu fazer, uma transfiguração do lugar comum em um lugar novo, inventado. $\mathrm{O}$ interesse de Freud pela criação artística se desdobra no questionamento sobre o que a psicanálise pode aprender com a arte e, em seu percurso

\footnotetext{
${ }^{6}$ Manoel de Barros (2008, p. 68).
} 
teórico, convoca desde a expressão estética até o processo de criação poética e subversão da linguagem como interlocutores da prática analítica.

Freud encontrou na arte um ponto no qual apoiar suas descobertas sobre o inconsciente e, consequentemente, suas formulações teóricas, seja procurando elucidar os enigmas relativos às emoções e à subjetividade, seja destacando aproximações estruturais como os jogos de palavras, a criação de outra realidade, a encenação, a preservação e o interesse pelo enigma. Segundo ele, há um trabalho na criação poética no qual a forma dada à obra de arte permite um jogo de luz e sombra, de dito e de dizer, de comunicação e de equívoco, o que faz com que o leitor sinta, ao mesmo tempo, um distanciamento e uma intimidade com o que aparece nos textos poéticos.

Lacan, no retorno que faz a obra freudiana, enfatiza a relação entre o campo da psicanálise e o da arte pelo viés da linguagem. Em aula a estudantes de letras, Lacan relembra a importância que Freud confere à literatura, apontando a universitas litterarum como o lugar ideal para a psicanálise. O especial interesse de Lacan pela poesia aponta para o que permeia seu ensino: o sujeito como um efeito de linguagem em sua estrutura e em sua incompletude, ou seja, naquilo que é possível ser veiculado pela palavra - o significante - e naquilo que a estrutura simbólica da palavra não consegue abarcar, o real, a letra, o traço radical de um sujeito. A poesia traz, em seus mecanismos de linguagem, formas semelhantes de articulação e de uso da palavra à função e à organização do significante e da letra no inconsciente.

A linguagem é o instrumento da psicanálise e da poesia. Freud, ao descrever as manifestações do inconsciente - sonhos, atos falhos, chistes, sintomas -, desvela a estrutura de linguagem presente no inconsciente, demonstrando a relação linguagem e inconsciente como determinantes do sujeito. É Lacan, no entanto, quem formaliza tal relação, afirmando que o inconsciente funciona segundo as mesmas regras da 
linguagem, enfatizando a linguagem como condição para o inconsciente e propondo que, para explicar a constituição do sujeito, é necessário considerar, primeiramente, o campo a partir do qual ele se constitui: o campo da fala e da linguagem.

Com Lacan, vemos, por meio da primazia do significante e do conceito de letra, a aproximação entre a linguagem do inconsciente e a linguagem poética. Ao subverter o algoritmo saussuriano que encerra o signo, trazendo como marca distintiva a primazia do significante, Lacan coloca o significante na posição de comando, apontando que há algo mais no significante que o significado não dá conta. Essa subversão, feita por Lacan, marca com precisão de que se trata a linguagem que vigora no inconsciente e, portanto, na clínica psicanalítica: a linguagem em seu aspecto sonoro, uma linguagem vazia de sentido e que, justamente por isso, pode abrigar as mais diversas significações, onde cada sujeito poderá produzir sua significação, única e singular.

Os significantes (simbólicos), que marcam cada sujeito, tocam um traço que porta a singularidade radical do sujeito por alojar-se em um ponto o qual a palavra não alcança, mas contorna, esse ponto é a Letra. Lacan situa a Letra como "litoral, separando territórios distintos, como aquilo que do simbólico constitui a borda que avança sobre o real" (Ribeiro, 2000, p.72). A Letra, então, é uma marca real, despojada de sentido, que limita a cadeia significante, apontando a impossibilidade do sujeito se representar todo pelo significante. Nela está inscrita a forma de gozar de cada sujeito, a marca que insiste em suas repetições.

Chegamos ao ponto que nos permite pensar a linguagem que vigora na clínica psicanalítica, a saber, a linguagem cifrada, equivocada, que se apresenta como senha para o inconsciente na medida em que se serve do simbólico para veicular o real do trauma. 
Um dia Lacan estava falando de sua prática durante seu seminário L 'Insu que sai de l’Une-bévue: "Só a poesia permite a interpretação. E é por isso que já não consigo, na minha técnica, que ela se mantenha; não sou suficientemente pohâte." Na verdade, ele acaba de dizer nesse seminário que a poesia é um efeito de sentido, bem como um efeito de furo. Poète [poeta] é sentido. Pohâte é furo. Foi em 17 de maio de 1977 (Julien, 2009, p. 51).

A linguagem que vigora no campo da poesia não se submete à significação estática, é uma linguagem que se produz a partir da subversão do código da língua, uma licença para que algo novo se produza visando a um efeito estético e a uma abertura à pluralidade de sentidos. Para tanto, podemos pensar que ambos os campos do conhecimento apontam para uma linguagem homofônica e polifônica, que não se encerra no exercício da língua enquanto código social. São estruturas de linguagem que privilegiam o não-dito como abertura à interpretação.

Sobre o lugar da interpretação na experiência psicanalítica, partimos da linguagem permeada pelo equívoco como forma de acesso à verdade de cada sujeito. A linguagem cifrada, sabemos, é a linguagem presente tanto na estrutura do inconsciente, como na poesia. Por isso propomos pensar em que ponto a linguagem poética pode entrar como interlocutora na clínica psicanalítica: uma clínica que busca fazer emergir o vazio de sentido, para que seja possível a cada sujeito a criação de uma nova significação.

Na experiência analítica, por meio de um percurso que vai da palavra vazia (falar para nada dizer) à palavra plena (fala como revelação), "trata-se de ligar o sujeito às suas contradições, de fazê-lo assinar o que diz, e de engajar assim a sua palavra numa dialética” (Lacan, 1953-1954/2009, p. 299). A psicanálise, portanto, é uma prática dirigida àqueles que desejam questionar-se sobre sua posição na produção do seu 
sintoma e, com isso, acessar sua verdade. Essa verdade reside no inconsciente e aparece escondida sob o véu do sintoma.

Apoiado na transferência, o analista ocupa o lugar de suposto saber sobre essa verdade e é justamente por nada saber sobre ela que elege a palavra em seu valor significante, vinda do sujeito, como veiculadora de um saber que não se sabe, um saber inconsciente.

$\mathrm{Na}$ análise, a verdade surge pelo que é o representante mais manifesto da equivocação - o lapso, a ação a que se chama impropriamente falhada. Nossos atos falhos são atos que são bem sucedidos, nossas palavras que tropeçam são palavras que confessam. Eles, elas, revelam uma verdade de detrás. No interior do que se chamam associações livres, imagens do sonho, sintomas, manifesta-se uma palavra que traz a verdade (Lacan, 1953-1954/2009, p. 345).

A linguagem poética pode contribuir com a psicanálise nesse ponto da autoridade da palavra enquanto significante vazio de sentido, despojado de significado. É neste ponto que reside a Letra. Segundo Mandil (2003), quanto mais funcionando como Letra, mais o significante produzirá uma significância em direção à verdade do sujeito. "Residiria aí o poder poético das palavras, qual seja, o de evocar uma multiplicidade de significações por meio de um movimento de suspensão de qualquer decisão semântica" (Mandil, 2003, p. 31). A poesia respeita a língua enquanto patrimônio coletivo criando comunidade e identidade e, ao mesmo tempo, mantém em exercício a língua individual (Eco, 2003). É necessário desarrumar a linguagem, diz Manoel de Barros (2008), para chegar mais perto das fantasias e desejos inconscientes.

A poesia assim, como a psicanálise, mostra como utilizamos a linguagem e como somos surpreendidos por ela. É no inesperado da frase onde uma palavra irrompe fora de hora, fora da continuidade sintática, que um efeito novo se produz. Pela poesia é 
possível privilegiar a acústica das palavras, a lalação contida no ritmo, na sonoridade e na harmonia.

Há um ponto, porque não dizer cego no psiquismo, em que não é possível ver o que se passa, no qual a compreensão falha e a interpretação explicativa não basta para traduzir o sintoma. A interpretação é uma criação do analisando a partir do furo que a marcação/ato/intervenção do analista provoca em sua fala. Ao pontuar, o analista abre uma passagem para um vazio criador, a possibilidade de uma nova produção. A marcação de um significante que produz negação de sentido faz furo no simbólico, graças à Letra que, como traço real, resiste à simbolização e, com isso, conduz à singularidade do sujeito, nos diz Julien (2009).

Se o funcionamento do inconsciente supõe como efeito a cifra, cabe à interpretação decifrar tal texto, decifrar aqui entendido como transliterar - o que é precisamente da ordem do não-sentido, uma vez que o resultado se dá a ler mantendo a equivocidade, efeito do real, como impossível de ser dito (Ribeiro, 2000, p. 71).

Recorrer à Poesia é admitir a necessidade de um encontro com o vazio de sentido. É deparar-se com o furo que o equívoco provoca no saber, apontando que a palavra não deve ser tomada com fixidez, ao contrário, seu poder deve residir no fato de que ela comporta o vazio em sua estrutura. A palavra deve esvaziar-se do seu sentido habitual e, com isso, suscitar algo novo, inesperado. Recorrer à linguagem poética no manejo clínico psicanalítico é apostar em uma interpretação que faça um furo no sentido, abrindo um espaço vazio no qual, no lugar da angústia advinda da repetição, se interponha um vazio criador. 


\subsection{O irrepresentável entre psicanálise e poesia}

Quero pintar uma tela branca. Como se faz? É a coisa mais difícil do mundo. A nudez. O número zero. Como atingi-los? Só chegando, suponho, ao núcleo último da pessoa. Clarice Lispector ${ }^{7}$

O vazio é a morada do irrepresentável. Em psicanálise, esse vazio é definido como aquilo que faz fronteira com o gozo da fala, apontando os limites da linguagem que não pode representar tudo, pois há em seu centro um irrepresentável que convoca um gozo fora do domínio da palavra, situado no campo do real. O real é o registro essencial do trabalho analítico, ponto central em torno do qual gira o campo das significações e, ao mesmo tempo, o centro é o furo, lugar vazio de significação, lugar do non-sense.

Maria Rita Kehl (1998), no texto O irrepresentável existe?, afirma que o real está sempre lá, no centro de tudo, e que os seres de linguagem vivem a ampliar continuamente os limites do simbólico em uma tentativa de recobrir o real, ainda que nunca possam fazê-lo completamente, pois "de cada experiência, de cada objeto, de cada percepção, fica sempre um resto que não conseguimos simbolizar; o núcleo duro das coisas" (p. 67).

O encontro com o real é o encontro com o irrepresentável, com o fora da linguagem, temido pelo sujeito por portar o ciframento das três dimensões fundantes da existência humana: o sexo, a mãe e a morte. Segundo Kehl (1998), esses encontros são marcados pelo apagamento do sujeito, momento de uma passividade absoluta em que o sujeito aparece assujeitado. O sujeito como tal é definido pela linguagem, reconhece o mundo e se reconhece por meio da linguagem e é nessa posição que ele é ativo em suas ações no mundo.

\footnotetext{
${ }^{7}$ Clarice Lispector (1978, p. 162).
} 
Para a autora, essas três dimensões fundamentais da existência humana ficam fora do alcance da representação: o ato sexual, no qual o sujeito foi concebido e o exclui radicalmente; o ventre materno, lugar de morada do sujeito em um momento em que não há por parte dele nenhuma participação ativa; e a morte, porque o morto ainda é a pessoa que viveu, mas já não sabe nem mesmo que está morto. Nessas dimensões, o sujeito é invadido pelo real e "é a completa passividade do sujeito (que no caso nem deveria ser chamado "sujeito") diante de um acontecimento que o torna irrepresentável para esse sujeito" (Kehl, 1998, p. 67).

A posição de completa passividade coloca em evidência o gozo fora da linguagem. Nessa posição, o sujeito se depara com a tela em branco, com o lugar vazio, apontando para um obscurantismo e, diante da falta de ancoragem simbólica, o horror se mistura a um fascínio. Segundo Kehl (1998), o fascinante do irrepresentável consiste no fato de que seu obscurantismo, ao mesmo tempo em que faz obstáculo, incita, produz gozo.

Porque o irrepresentável nos fascina? Tenho impressão de que o fascínio pelo indizível, que quando não se resolve na experiência poética traz sempre uma dimensão obscurantista, é uma versão do fascínio pelo absoluto. Fascínio que pode nos levar ao silêncio, ou à tela em branco (Kehl, 1998, p. 68).

O indizível, na cena do sujeito, aparece em uma equivalência à tela em branco e produz um efeito de silêncio, de apagamento, o que coloca em função a angústia e, também, a criação. A angústia é o sinal do real que anuncia a falta-de-significante, ela é um pré-sentimento que anuncia a proximidade do real. Lacan (1962-1963/2005), no Seminário 10, A angústia, a localiza como uma hiância entre o desejo e o gozo, numa relação estreita com o objeto $a$. O $a$ é o ponto irredutível, é um resto, “justamente o que resiste a qualquer assimilação à função do significante, e é por isso mesmo que 
simboliza o que, na esfera do significante, sempre se apresenta como perdido" (p. 193). O objeto $a$ vem marcar a presença do vazio, na medida em que oferece um contorno à falta. Enquanto resto, ele é o que sustenta (como falta), o que anima o desejo e a cadeia de linguagem do ser falante. No entanto, para que sua função se cumpra o lugar do objeto $a$ deve permanecer vazio, sendo a angústia, o sinal de sua proximidade.

A criação, por sua vez, é uma ação que opera uma transformação no estatuto desse vazio, que sai da condição de presentificação do buraco, própria à angústia, assumindo um espaço propício à criação. Antes de se tratar de uma cobertura simbólica do real insuportável, a criação oferece um destino ao que não pode ser significantizado, o que faz dela um trabalho nos contornos do real, fazendo fecundo o vazio.

Lacan (1959-1960/2008), no Seminário 7, A ética da psicanálise, propõe uma leitura a respeito da criação, articulando-a a clínica psicanalítica. Para tanto, ele convoca o conceito de das Ding, a Coisa, definida por Freud "em sua situação central quanto à constituição da realidade do sujeito" (p. 144). A Coisa se apresenta sempre como unidade velada, como o ponto no aparelho psíquico que não se entrega à articulação significante. Segundo Lacan, a primeira relação que se constitui no sujeito se cristaliza no sistema psíquico em elementos significantes. A organização significante domina a rede de representações constitutivas do aparelho psíquico, entretanto, o "lugar central sob o qual o campo da Coisa, como tal, se apresenta para nós" (p. 145), não coincide com essa organização.

O campo no qual está situada a Coisa é o lugar do objeto perdido, motivo de o sujeito recorrer continuamente ao significante numa tentativa de reencontrá-lo, de representá-lo. O objeto perdido é procurado pelo sujeito nas vias do significante, comandado pelas leis do princípio do prazer que conduz o sujeito a deslizar de significante em significante, buscando manter o nível mais baixo possível de tensão no 
aparelho psíquico. No entanto, pela via do significante ele só tem potência de representar a Coisa, como lugar do objeto perdido, pela via da criação do objeto.

A Coisa - das Ding - é o lugar enigmático da origem, lugar do irrepresentável e, ao mesmo tempo, da constituição do sujeito. Sendo seu campo o real, há uma disjunção entre significante e gozo, o que aponta para o Outro gozo, gozo do corpo. No Seminário 7, Lacan afirma que é nessa disjunção que se apresenta o vazio de angústia e o vazio da criação e que a linguagem, na psicanálise e na arte, encontra sua subversão e seu limite.

Aqui está nosso encontro marcado com o emprego da linguagem que, pelo menos para a sublimação da arte, nunca hesita em falar de criação. A noção de criação deve ser promovida agora por nós, com o que ela comporta, um saber da criatura e do criador (Lacan, 1959-1960/2008, p. 146).

A arte se organiza em torno do vazio e, segundo Lacan (1959-1960/2008), o ato de criação consiste na "transformação de um objeto em uma coisa, a elevação repentina da caixa de fósforos a uma dignidade que ela não tinha de modo algum anteriormente" (p. 144). Ele toma como exemplo o oleiro em seu trabalho de criação em torno do vazio na modelagem do vaso.

Ora, se vocês considerarem o vaso, na perspectiva que inicialmente promovi, como um objeto feito para representar a existência do vazio no centro do real que se chama a Coisa, esse vazio, tal como ele se apresenta na representação, apresenta-se, efetivamente, como um nihil, como nada. E é por isso que o oleiro, assim como vocês para quem eu falo, cria o vaso em torno desse vazio com sua mão, o cria assim como criador mítico, ex nihilo, a partir do furo (Lacan, 19591960/2008, p. 148).

Em toda forma de criação, o vazio é determinante. "Toda arte se caracteriza por um certo modo de organização em torno desse vazio" (Lacan, 1959-1960/2008, p. 158), 
ela, assim como a psicanálise, é orientada pelo real e, por esta relação com o real, o que entra em cena são modos de satisfação situados mais além do prazer, modos de gozo ligados ao vazio da Coisa, uma vez que a Coisa, precisamente pelo fato de não poder ser representada em si mesma, será sempre representada por um vazio modelado pelo significante. Na arte, a criação permite uma articulação significante capaz de resguardar o vazio da Coisa. No âmbito da linguagem, em que se lida em todos os casos com o significante, "é o que, na ordem das artes, confere sua primazia à poesia" (Lacan, 19591960/2008, p. 166).

Lacan (1959-1960/2008) afirma que há uma função do poeta que o diferencia do homem comum. Isto foi dito por Freud, em Escritores criativos $e$ devaneios, e enfatizado por Lacan, no Seminário da Ética. Segundo ele, na criação não se trata simplesmente de benefícios secundários que os indivíduos podem extrair das produções, mas, sobretudo, "a possibilidade original de uma função como a função poética" (p. 176). Para falar dessa função, Lacan convoca o amor cortês que, em certa época da história (entre o século XI e o século XIII), afetou o consenso social de maneira sensível. Os jogos de sons e palavras ligados a um ofício poético surgiram nessa época e o ponto de partida do amor cortês é ser um amor infeliz por trazer em seu centro a figura inacessível da Dama, em uma época em que nada parecia responder à liberação da mulher, pois, na sociedade feudal, a mulher era identificada com uma função social, sem lugar para sua liberdade pessoal.

“É nesse contexto que a curiosíssima função do poeta do amor cortês se põe a se exercer" (Lacan, 1959-1960/2008, p. 179), a jogar com certo número de temas idealizantes, colocando em primeiro plano a Dama, objeto feminino que se introduz pela inacessibilidade: "não há possibilidade de cantar a Dama, em sua posição poética, sem o pressuposto de uma barreira que a cerque e a isole" (p. 179). A Dama é 
apresentada com caracteres despersonalizados, o que faz parecer que está se dirigindo sempre para o mesmo lugar.

Lacan (1959-1960/2008) afirma que "nesse campo poético, o objeto feminino é esvaziado de toda substância real" (p. 179), o que faz com que o vazio do feminino sustente em torno de si as mais variadas significações, no caso do amor cortês, idealizações. Essa organização demonstra que no centro do sistema de significantes que é o campo da representação - se encontra o vazio da Coisa - o irrepresentável lugar em que Lacan situa o trabalho de criação da poesia.

“É aqui que devemos trazer a necessidade de Lacan de buscar na poesia ou, mais especificamente, na função poética, um outro suporte teórico para a interpretação" (Ramos, 2013, p. 46). Ramos afirma que Lacan entrelaça psicanálise e poesia pela via do significante, propondo a equivocação como base da interpretação analítica; e pela via da letra, a partir do trabalho com o irrepresentável, o indizível, apostando em um savoirfaire, um saber-fazer com o mais de gozo que não se articula pela cadeia do sentido.

Para o autor, o que entra em jogo na função da interpretação é a questão econômica de produção de gozo e enfatiza a importância da entrada "das combinações de sons, fonemas e escansões para a produção de efeitos de sentidos” (Ramos, 2013, p. 47), no tocante à clínica psicanalítica. Isso acontece não somente na medida em que estas combinações produzem uma significação, mas, também, no que operam na economia subjetiva, permitindo um alívio nas tensões psíquicas a partir da equivocação que o significante produz, bem como a localização da letra como ponto material que nos permite registrar o gozo de cada sujeito, mais particularmente sua forma de gozar.

Funcionando como objeto $a$, a letra se apresenta de duas formas: uma, como suporte da mensagem, comum na neurose; e outra, sua natureza de dejeto, mais observado na psicose, onde não tem função, mas destino. Os psicóticos, assim como os 
poetas e alguns escritores, fazem da letra rasura e litoral, numa "acomodação de restos" - conforme assinala Lacan (1971/2003) em Lituraterra, para situar o simbólico na borda do real (Sobral, 2008).

Lúcia Castello Branco (2000), em seu livro Os absolutamente sós, observa que os poetas e os psicóticos parecem saber bem do processo de redução da palavra a seu caroço, sua materialidade, seu ponto de letra. A letra, no ensino de Lacan, se reporta ao que há de mais fundamental na escrita do corpo onde se inscreve um sujeito. Ela "borda justamente o furo, justamente o buraco que suporta toda e qualquer construção simbólica" (p. 23). Assim, a letra é o ponto de furo, pois ela aparece como marca da palavra que falta ao mundo das palavras, por "onde toda a significação escoa (como no "umbigo do sonho")", para onde "convergem também todas as significações possíveis (e impossíveis), todas as linhas mestras, como no ponto de fuga" (p.28).

O ponto de furo é também um ponto de fuga. "E não será também esse o ponto da poesia? Ponto em que as palavras se exibem em sua materialidade sonora, ou em sua materialidade plástica?” (Branco, 2000, p. 29). Branco afirma que para chegar ao ponto poético das palavras é preciso reduzi-las a seu ponto de letra, puro traço que marca o vazio inscrito na linguagem. A escrita poética busca, como se possível fosse, o além da linguagem, o irrepresentável, o real. E conclui que "só assim, a partir da redução da narrativa ao ponto poético da palavra e de redução da palavra a seu ponto de letra, a seu ponto $p$, pode-se renomear as coisas" (p. 22).

Lacan (1965/2003), na homenagem que tece à Marguerite Duras, destaca a função da letra na localização de um gozo enredado pelo arrebatamento vivido por Lol V. Stein, personagem do livro de Duras, La ravissement de Lol V. Stein. Na cena do baile, cena central no livro, Lol fica muda diante da mulher que entra no baile, toma seu noivo numa dança e o rouba definitivamente. Fica muda porque não há palavra que 
possa dar conta desse encontro com uma mulher que encarna, para ela, o lugar d'A mulher, que surge como um real arrebatador deixando Lol diante da vacuidade do corpo. Lol persegue a letra no indizível do corpo da Outra mulher e o silêncio se faz forte e fechado.

Se Lol está silenciosa na vida é porque acreditou, no espaço de um relâmpago, que essa palavra podia existir. Na falta de sua existência, ela se cala. Teria sido uma palavra-ausência, uma palavra-buraco, escavada em seu centro para um buraco, para um buraco onde todas as palavras teriam sido enterradas (Duras, 1986, p. 35).

Lol se encontra sem a posse do seu corpo, fascinada, presa ao corpo da Outra mulher numa espécie de êxtase, experimentado por um estado fora de si. No instante do baile, Lol é totalmente invadida por um gozo sem limites, um empuxo ao gozo feminino, ela então silencia, afirma Lacan (1965/2003). Sobre a cena, nunca mais foi dita uma única palavra, não era possível dar uma cobertura simbólica a uma experiência com tamanha estreiteza com o real. Com a partida do noivo, um vazio se abre para Lol, nenhuma significação se faz possível, nenhuma identificação, nenhuma nomeação, pois no arrebatamento, Lol é assujeitada a um gozo que frui a partir de uma desapropriação do corpo.

Aqui retomamos os apontamentos de kehl (1998) sobre a experiência com o irrepresentável - uma experiência de passividade absoluta onde o corpo encontra-se desamarrado da linguagem e da imagem - para localizar o arrebatamento como um modo de fascínio diante do irrepresentável, efeito de um instante marcado pela não articulação do corpo pelo simbólico, pela não inscrição do corpo no desejo do Outro.

Na homenagem a Marguerite Duras, Lacan (1965/2003) desenvolve essa questão do arrebatamento pela função da letra na localização desse gozo que se dá no terreno do 
irrepresentável. Segundo ele, a função da letra é fazer um furo no real por onde possa passar uma costura que se dá à maneira de um nó, enodando real, simbólico e imaginário. E evidencia que o que está em jogo na letra é operar no ponto onde a significação falha e a interpretação não dá conta de agir sobre o sintoma. No lugar indizível do corpo da mulher, a interpretação encontra um limite. Nesse aspecto, não se trata de buscar um trabalho nos domínios do sentido, mas sim buscar um saber fazer com o gozo a mais que não encontra representação no psiquismo do sujeito.

O estudo do irrepresentável, portanto, ao colocar em cena as particularidades do real, sinaliza os limites da interpretação. Pierre Bruno (2007), em seu texto L'occulte et le réel, chama a atenção para o fato de que Freud, na análise dos sonhos, aponta para os limites da interpretação, questionando sobre a significação oculta dos sonhos: todo sonho tem um sentido? É possível dar a cada produto do sonho uma tradução completa pela via da interpretação? E segue pontuando que há uma parte oculta no sonho que escapa à interpretação, uma parte cifrada, inacessível ao sentido.

No estudo dos sonhos, Freud indaga se é possível colocar na linguagem tudo que se passa no sonho. O funcionamento dos sonhos segue o propósito dos processos mentais que demandam um ganho imediato de prazer, recorrendo à estrutura simbólica para colocar em cena os desejos recalcados. Entretanto, Freud observou que o sonho gira em torno de um núcleo que não se entrega ao simbólico, preservando-se sigiloso, obscuro e afirmou ser em torno desse núcleo que se movimentam as produções oníricas. Esse ponto resistente, vazio de sentido, é o umbigo dos sonhos.

O umbigo é o suporte do real no sonho, ele indica que ainda que o saber inconsciente ganhe uma decifração nunca será feito de forma completa. Bruno (2007) afirma que a noção de limite aí se impõe pelo fato de haver entre o simbólico e o real uma decalagem, o que faz com que, em se tratando do ser falante, nunca haja um 
recobrimento completo da linguagem sobre o real. Para Lacan (1965/2003), Marguerite Duras fez do umbigo um ponto de criação. A escrita literária permitiu que, por meio do trabalho com a letra - que tem função de fazer cifra como forma de amarração -, Duras desse uma nomeação ao irrepresentável do feminino, podendo conferir ao vazio de definição do feminino um destino criativo.

O irrepresentável na psicanálise e na poesia é fonte de trabalho, espaço de criação. É em sua direção que se desdobra a experiência analítica na busca de uma interpretação que tenha inspiração na palavra poética, visando à produção de um corte que faça furo no sentido, abrindo um ponto de fuga. O lugar do indecifrável não é traduzível, a única maneira de acesso a ele (se é que há alguma) é cifrá-lo. A intervenção do psicanalista, portanto, deve caminhar na contramão do sentido, alimentando-se dos achados, dos restos, à maneira dos poetas, como um apanhador de poemas. Na palavra poética de Mario Quintana (2007, p. 234):

Um poema sempre me pareceu algo assim como um pássaro engaiolado... E que, para apanhá-lo vivo, era preciso um cuidado infinito. Um poema não se pega a tiro. Nem a laço. Nem a grito. Não, o grito é o que mais o espanta. Um poema, é preciso esperá-lo com paciência e silenciosamente como um gato. É preciso que lhe armemos ciladas: com rimas, que são o seu alpiste; há poemas que só se deixam apanhar com isto. Outros que só ficam presos atrás das catorze grades de um soneto. É preciso esperá-lo com assonâncias e aliterações, para que ele cante. É preciso recebê-lo com ritmo, para que ele comece a dançar. E há os poemas livres, imprevisíveis. Para esses é preciso inventar, na hora, armadilhas imprevistas. 


\subsection{O trabalho com o feminino e o irrepresentável na clínica psicanalítica}

Lacan, na época em que constrói as fórmulas da sexuação, pergunta-se muitas vezes sobre o lugar do feminino na lógica mesma da experiência analítica, e ele diz que o analisável é dessa ordem. Nieves Soria Dafunchio ${ }^{8}$

A clínica psicanalítica foi fundada por Freud como uma prática de acesso ao inconsciente pela fala. A regra é falar livremente apostando em uma associação que se dá no próprio instante em que se fala, estando, assim, mais livre dos arranjos e articulações já sedimentados no psiquismo do sujeito. O que a fala analítica vem trazer para a cena do sujeito é o engendramento de um saber cifrado que é convocado a aparecer no percurso da experiência analítica.

Marie-jean Sauret (2006), no texto Le féminin et lien social, enfatiza que a associação livre é o modo de intervenção clínica na psicanálise pelo fato de que no cerne da experiência analítica está a relação do sujeito com a linguagem, o que justifica o recurso à palavra como forma de acesso ao inconsciente. Sauret afirma que, de um ponto de vista lógico, a linguagem preexiste ao sujeito e essa alteridade da linguagem em relação ao sujeito foi chamada por Lacan de grande Outro.

A noção de grande Outro, que vimos se articular no percurso deste trabalho de tese às mais diversas instâncias da vida do sujeito, é virtualmente o lugar da verdade, lugar da fala, em que Lacan localiza o inconsciente, afirmando que "o inconsciente, é o discurso do Outro" (Lacan, 1964/1998, p. 126) e pontuando ser esse o princípio que possibilita a experiência analítica.

O inconsciente, ao se manifestar por meio de formações que demonstram o fato de o sujeito ser, em certos momentos, ultrapassado pela linguagem - como ocorre nos chistes, nos atos falhos, nos sonhos e no próprio sintoma -, depara o sujeito com a

\footnotetext{
${ }^{8}$ Dafunchio (2013, p. 67).
} 
alteridade da linguagem, que substitui, desloca, alitera, marcando que o sujeito não é o senhor da própria casa, que há um saber que se encontra cifrado e que este saber está no campo do Outro.

De acordo com Sauret (2006), o sujeito, para responder à convocação da vida, das demandas parentais, vai procurar os significantes no campo do Outro, pois o significante é a molécula que engendra o processo de fabricação da significação. Isolado, o significante não significa nada, se ele participa da representação é devido à sua condição de articulação a outro significante - essa é a lei simbólica constitutiva da linguagem e, consequentemente, estruturadora do psiquismo.

A primeira coisa que o significante representa é o sujeito por meio da articulação com outro significante na enunciação do ato da fala. O significante representa o sujeito. Entretanto, o faz de forma não-toda, uma vez que o real do sujeito é inacessível ao significante e assim permanece, sendo essa disjunção a responsável pela fundação do inconsciente. Segundo o autor, o inconsciente é definido, por Lacan, como um saber impossível de ser incorporado ao sujeito porque ele é sempre Outro. Há uma falta no lugar do significante que, supostamente, restituiria o gozo perdido, há uma falta significante no campo do Outro, falta que aponta de um lado para a cadeia do desejo e, do outro, para o campo do gozo, afirma Sauret (2006).

A cadeia do desejo é situada por Lacan em relação ao gozo fálico, articulado pelo significante. É o gozo que do corpo se inscreveu na linguagem e ganhou uma representação psíquica, é o gozo do sujeito com a palavra naquilo que ela tem de produtora de sentido, naquilo que faz engendrar a significação. O gozo do ser falante é o gozo do significante graças ao qual a associação livre se torna um instrumento clínico na psicanálise, nela o significante desliza associando-se a outros significantes de maneiras tão diversas de sujeito a sujeito. 
É, portanto, a ligação fundamental do sujeito com o universo das palavras que torna possível a experiência psicanalítica. Isso não quer dizer que se encerre na linguagem o que se passa no campo do gozo quando se trata o sujeito do inconsciente. Há um excedente de gozo que não se representa pelo significante no psiquismo do sujeito e que comparece como um gozo a mais, um mais-de-gozo. É o que desenvolvemos ao longo deste trabalho de tese e que fomenta a discussão clínica sobre o modo de intervenção em relação a esse gozo Outro, fora da linguagem, gozo feminino.

De toda maneira, afirma Lacan (1971-1972/2011), “não há uma só interpretação analítica que não seja feita para dar a uma proposição encontrada sua relação com um gozo" (p. 60). Esse é o ponto central da teoria psicanalítica. Segundo ele, a interpretação visa sempre a assinalar o que é do registro do gozo porque quando se trata do ser falante, o espaço aberto entre significante e significado evidencia a falta fundamental, em torno da qual gira toda a estruturação do psiquismo e sua articulação à cadeia da fala. Miller (1997) afirma que o gozo está situado nessa decalagem entre significante e significado, o que "o conduz a afirmar que, quando alguém fala, nunca consegue dizer aquilo que quer, ou diz alguma outra coisa que não é o que queria dizer, ou revela que, o que quer dizer em verdade é diferente do que está dizendo" (p. 460).

Fala e falta, portanto, se articulam, essa é a ética do discurso psicanalítico. Ao falar, na experiência analítica, o sujeito coloca em cena tanto as repetições linguageiras de discursos que estão em sua vida familiar e social, como é surpreendido pelo que sai da sua boca à revelia do $e u$. A fala do sujeito é convocada à equivocação, à vacilação, a outras leituras, e o inconsciente pode emergir num lapso, num chiste, num sonho, trazendo à tona a expressão de um desejo. 
No que tange ao Outro gozo, a interpretação encontra um limite, pois, estando fora dos domínios da linguagem, este gozo não tem função de mensagem, não vem enunciar a posição subjetiva do sujeito na linguagem como faz o gozo fálico. Sendo ele fruto do furo que há na linguagem, seu campo de fruição é o que do corpo restou irrepresentável.

Sobre as duas modalidades de gozo do ser falante na clínica psicanalítica, Dafunchio (2013) faz uma leitura clínica a partir das fórmulas da sexuação, afirmando que os dois lados do quadro, sendo posições, podem indicar vias de trabalho analítico. Do lado esquerdo, seguindo a lógica do significante há uma aposta no enredo linear da análise como um percurso com começo, meio e fim. Do lado direito, outra perspectiva se mostra, "uma perspectiva que trata de pedaços do real que estão soltos" (p. 60), onde é necessário um trabalho com a letra, uma vez que a linearidade não é sua marca. Sua marca é o irrepresentável, aquilo que o significante não abarca, onde só se toca no trabalho feito nessa borda que a letra demarca entre o simbólico e o furo real que há em seu centro.

São duas leituras do trabalho analítico. Na primeira, estamos na via da interpretação analítica no sentido de tomar o inconsciente, em sua vertente simbólica, como um saber do qual o sujeito não sabe que sabe. A regra é falar livremente, associando significantes que passam a reordenar o campo do sujeito em torno do questionamento sobre seu desejo, mais propriamente sobre sua posição frente a seu desejo, nos domínios do gozo fálico. Essa via de saber faz Lacan questionar e ressaltar os perigos de reduzir o sujeito ao significante, ou, como afirma Dafunchio (2013), de reduzi-lo a um diagnóstico, colocando o saber a frente do sujeito.

A autora retoma Freud, indicando que, em sua proposta de "escutar cada caso como se fosse o primeiro, deixando de lado todo o saber" (p. 61), Freud mostra a 
inclinação ao feminino como estando no cerne do trabalho analítico. Embora o discurso analítico se desdobre na lógica fálica, pois só é possível tomar o ser falante na dimensão simbólica do dizer, Lacan afirma que "o feminino está no centro cego da experiência analítica" (Dafunchio, 2013, p. 67) e que a análise se desenvolve nas bordas, em torno do buraco do feminino.

Falemos então da outra via, aquela que está situada do lado direito do quadro, a via feminina de um trabalho analítico. Tomar o sujeito em sua singularidade, no um a um, sem generalizações - não é essa a lógica feminina definida por Lacan no quadro da sexuação? Aqui se trata de outra relação com o saber, em que está em jogo propriamente o irrepresentável, essa falta de significante no campo do Outro. O analista encarna esse vazio no saber, ele passa a ter uma relação direta com essa falta do significante no Outro, passando a uma abordagem do inconsciente em sua vertente real. A presença do analista encarna o feminino na medida em que encarna o vazio em torno do qual gira a ordem simbólica e gira a análise (Dafunchio, 2013).

Parece-me que é aí onde se determina o ponto central da posição no final da análise do sujeito em sua relação com o saber, seja ele homem, seja mulher, porque aqui não se trata da relação entre os sexos, mas sim da relação do significante da falta do Outro (Dafunchio, 2013, p. 68).

O feminino, vimos no desenrolar deste trabalho, é o campo da sexualidade com o qual todo sujeito se depara como enigma. Este enigma parte do lugar materno no ponto de disjunção entre a mãe e a mulher, pois nascidos de uma mãe, todos os sujeitos, no traçado de sua história e, principalmente, na inscrição de sua subjetividade, se deparam com a questão da relação da mulher com a falta. Esta relação porta um traço específico sob a forma de um mais-de-gozo, um gozo que se encontra mais além do gozo fálico. 
Maud Mannoni (1999), no livro Elas não sabem o que dizem, afirma que o gozo feminino ultrapassa o significante e, portanto, não se define por ele. Segundo ela, o feminino se manifesta fundamentalmente como gozo, um gozo radicalmente singular que tende ao infinito, e que isso coloca o feminino numa relação estreita com o impossível de dizer. Neste livro, a autora faz uma leitura da relação de Virgínia Woolf com o mundo das palavras, localizando sua escrita como uma maneira de tocar o inominável, o irrepresentável.

Segundo Mannoni (1999), a escrita pode servir como uma maneira de dar destino ao que é da ordem deste gozo Outro, uma criação diante da falta de um significante no campo do Outro que represente o feminino, o que faz a autora questionar se nesse campo "não somos arrastados para um ponto não-interpretável, um território "outro", diferente do território do sentido sexual? Um lugar que só o poeta poderia evocar?" (p. 90).

Uma vacuidade, um universo sem palavras, furo no simbólico. Pommier (1987) alude à poesia como um trabalho que se desdobra nesse espaço que denuncia a precariedade do abrigo que a linguagem oferece ao ser falante - o espaço do irrepresentável. "Quando considera as palavras em si mesmas, quando trabalha sua materialidade, o poeta relega a segundo plano sua significação" (Pommier, 1987, p. 98), abrindo acesso ao gozo, na medida em que o gozo se "deve à materialidade contrariada do significante" (p. 98), captada na sonoridade das palavras, por meio da qual "o poeta mostra até onde as palavras nos transportam, para quem as sabe ouvir e perceber a totalidade que evocam" (p. 99).

Segundo Pommier (1987), a sonoridade margeia um abismo, aproxima-se da loucura por atuar na ausência de garantia estrutural da própria linguagem. Quando se isola uma palavra pelo seu aspecto sonoro, se dá uma perda de identidade da palavra 
que passa a evocar o todo das outras palavras. Isso ocorre porque um espaço é aberto, as amarras da palavra se soltam da circularidade em que se encontravam no psiquismo do sujeito e passam a evocar o infinito, o ilimitado que há na própria palavra, "assim acontece com o poeta que escutará a palavra por seu valor plástico, mais do que por aquilo que ela designa" (p. 100), pois "o puro valor dos sons evoca o ato de dizer, para além de todas as significações que possa portar a língua, e também contra elas” (p. 104).

Nos encontramos aqui com a letra, a escritura, a materialidade que está impressa na sonoridade e que não se presta à compreensão, sua função é apontar o furo por onde o gozo traça sua costura. Na clínica psicanalítica, a intervenção que segue o rastro da letra, convoca o psicanalista a ler o que está escrito no que se ouve, ler o que da palavra não se presta às associações, não se articula na fala, fazendo furo no dizer.

Ler a letra é evacuar o sentido até ficar apenas um resíduo ineliminável: o sentido literal, o mais próximo do real da coisa, o mais próprio; ler a letra é forçar o nome a perder as suas valências imaginárias e simbólicas até ele quase coincidir com a coisa (Álvares, 2001, p. 09).

No Seminário 24, Lacan (1976-1977) convoca a poesia como a via de interpretação na clínica psicanalítica pelo fato de operar efeito de sentido e, também, efeito de furo, tocando assim, nas duas vias do trabalho analítico: a do significante e a da letra. Na lição de 17 de maio de 1977, Lacan afirma:

Je vous l'ai dit, avec de la poésie qui est effet de sens, mais aussi bien effet de trou. Il n'y a que la poésie, vous ai-je dit, qui permette l'interprétation et c'est en cela que je n'arrive plus, dans ma technique, à ce qu'elle tienne: je ne suis pas assez pouâte, je ne suis pas pouâteassez! (p. 65) ${ }^{9}$.

\footnotetext{
9 "Eu lhes disse que a poesia é efeito de sentido, mas também, efeito de furo. Não há mais que a poesia, eu lhes disse, que permita a interpretação e é por isso que eu não consigo em minha técnica isto que ela tem: eu não sou suficientemente pouâte, eu não sou pouâteassez" (Tradução livre).
} 
Ao construir o neologismo pouâte, Lacan alude a uma maneira de conjugar numa só palavra o poeta e o ato, questionando se o psicanalista seria poeta o suficiente em seu ato para fazer operar em sua prática os respectivos efeitos de sentido e de furo, indicando ser nessa direção que a psicanálise deve traçar seu percurso.

Ana Laura Prates Pacheco (2012) tece uma leitura da aproximação feita por Lacan no Seminário 24 entre a poesia e a experiência analítica, afirmando estar na interpretação, como ato que funda a especificidade do discurso psicanalítico, o motivo da convocação por Lacan da poesia. A interpretação permite ao psicanalista intervir com seu ato na fala do analisando, convocando a questão da verdade e a do sentido. Segundo ela, no ensino de Lacan, a verdade se encontra menos no nível semântico - $o$ que isso quer dizer - e mais no nível da estrutura - como isso diz-, o que aponta para o fato de que a interpretação é menos um método para se alcançar a verdade recalcada, ou uma técnica de decifração, do que uma tática relativa a uma política de cura.

A interpretação na psicanálise lacaniana, sabemos, deve visar ao significante. Entretanto, esse fato não é uma autorização para uma polissemia infinita, como se a interpretação estivesse aberta a qualquer sentido. Pelo contrário, uma interpretação é bem sucedida quando ela tem como efeito o surgimento de um significante irredutível.

Como propor uma clínica que possa ser orientada pelo que há de real na realidade do discurso do sujeito? Pacheco (2012) levanta essa questão para discutir o paradoxo que está presente na clínica psicanalítica: por um lado, a interpretação deve visar a extrair para fora da linguagem algo que está preso nela e, por outro lado, não há como operar essa extração a não ser passando pelo sentido. Acrescenta, ainda, que essas são vias indissociáveis na experiência psicanalítica, o que faz Lacan precisar recorrer de modo simultâneo ao matema e ao poema. 
O inconsciente como um saber falado é o que supõe o fato de ele poder ser interpretado, essa é a delimitação freudiana do inconsciente. A interpretação via matema, mostra, faz aparecer a causa do desejo, convocando a criação de uma subversão no plano da lógica (sobretudo as fórmulas da sexuação), evidenciando o entrelaçamento das palavras com a sexualidade quando se trata do humano. Ela corresponde à interpretação apofântica, aquela que tem por função iluminar, clarear o que se encontra escondido como resultado da castração. A via do poema corresponde à interpretação como equívoco, aquela que se desdobra num savoir-y-faire, um saber o que fazer com isso que é irredutível e que, por isso mesmo, convoca o sujeito à criação, à invenção de um significante novo, advindo da solidão, da unicidade vivida por cada sujeito.

Para Pacheco (2012) essa é a visada de Lacan quando provoca os psicanalistas, convocando-os a responder com a suficiência poética. Aqui, o paradigma é a interpretação pelo equívoco, na qual se privilegiam a homofonia, as brincadeiras e jogos com a língua, colocando em cena a mostração para além da demonstração, o que faz Lacan apelar para topologia como maneira de mostrar a impossibilidade de aceder ao real sem ser pelas palavras, enfatizando, no entanto, a necessidade de priorizar a ressonância, o som como uma via em que o psicanalista pode fazer ressoar outra coisa que o sentido.

Sobre as formulações feitas por Lacan no Seminário 24, Philippe Julien (2009) escreve sobre sua experiência como analisando de Lacan afirmando que o desenrolar da sua análise se desdobrou nos moldes do fazer poético, por ter promovido um efeito de sentido, mas também de furo. A pontuação, retomada de uma palavra que marca o fim de uma sessão, produz para Julien um furo na narrativa, abrindo um vazio criador, condição de uma nova produção na próxima sessão. A pontuação depende da fala do 
analisando, por isso produzida no um a um. Seu estatuto de furo diz respeito ao fato de que a pontuação produz um encontrão com o impossível da resposta do Outro e isso produz no sujeito um vazio. Esse impossível, entretanto, leva o sujeito a criar ele mesmo uma resposta inédita nos moldes de uma saída, de um destino. Para Julien, sua travessia operou uma passagem de analisando para analista.

À maneira do savoir-y-faire, Lúcia Castelo Branco (2000) articula a escrita poética de Maria Gabriela Llansol a um trabalho que tem função de ato poético por se tratar de uma escrita que faz buraco no simbólico, reduzindo a dimensão da narrativa à dimensão da palavra. Segundo a autora, a letra é o instrumento dessa escrita literal que delineia um litoral entre o simbólico e o real, pois ela "não representa nada, mas está ali, em sua literalidade, a marcar o ponto de furo, a fazer buraco no simbólico" (p. 37). Para a autora, alguns textos escrevem-se em ponto de letra, na medida em que neles a letra funciona com um anel amarrador a cifrar o real do gozo do sujeito, promovendo um modo de amarração entre o real, o simbólico e o imaginário.

A intervenção clínica na prática analítica visa a tocar justo na questão topológica da articulação entre o real, o simbólico e o imaginário - cerne das questões subjetivas. O que está em jogo na via feminina do trabalho analítico é a função de anel, que aponta para o fato de que não há uma amarração garantida entre os três registros, motivo da produção de sintomas e dos conflitos psíquicos, o que há é uma invenção que faça função de anel ao promover uma amarração que permita ao sujeito dar um destino ao irrepresentável, preservando, contudo, seu lugar, sua função de furo. Diante dos limites da interpretação, é a função de destino que se traduz em um savoir-y-faire que se coloca como possibilidade de trabalho analítico, um trabalho de criação, extremamente singular, feito (ou efeito) da solidão de ser um. 


\section{CONCLUSÃO}

Neste trabalho de tese, buscamos desenvolver de que forma o feminino e o irrepresentável se articulam na teoria psicanalítica. Ao percorrer os temas, descobrimos entre eles uma afinidade estreita, podendo o irrepresentável ser tomado como uma maneira possível de definir o feminino em seu traço específico. Como um tema sedutor e inesgotável, o feminino cria fascínio e interrogações por se tratar da esfera da sexualidade que resta a nomear no psiquismo. A falta de representação do gozo feminino - o Outro gozo - no inconsciente faz com que o feminino, naquilo que lhe é específico e único, nunca seja completamente dito. Há em seu centro um mistério nunca decifrado porque o que o constitui não é da ordem de um saber, de uma estrutura de linguagem, não sendo, portanto, transmissível. Em seu centro há um gozo que fica fora da articulação da linguagem.

O que faz do feminino um enigma é, portanto, esse ponto nunca recoberto pela palavra, onde habita um gozo mais próximo do gozo propriamente dito. A questão do gozo no ser humano, enfatizada por Lacan em seu ensino, é marcada por uma perda, que se dá devido à incidência da linguagem em seu mecanismo fazendo com que o gozo seja parcializado. A linguagem coloca em cena a lei do desejo que passa a regular o gozo, na medida em que o mecanismo do desejo se alimenta da falta gerada pela perda de gozo. A falta funciona como mola para o desejo, essa é a função engendrada pela castração, da qual o feminino se vale na orientação da sexualidade, mas o faz de forma não-toda. O irrepresentável do gozo se preserva no feminino como possibilidade, indicando que haverá sempre um vazio que é impossível de dizer e que diz respeito ao que do sexo não ganhou inscrição no psiquismo. 
Assim, ao falar do feminino, não basta discernir entre dois sexos, é, sobretudo, de uma divisão em relação a dois gozos que se trata: de um lado, o gozo fálico guiado pelas leis do desejo e, de outro, o gozo suplementar, não-todo fálico, que aponta um mais além. Do posicionamento em relação ao Outro gozo, Lacan extrai desdobramentos clínicos e convoca a psicanálise a orientar sua prática em direção ao real, afirmando que a interpretação na clínica psicanalítica precisa operar como uma intervenção no gozo e que, ao fazê-lo, irá se deparar com os limites da linguagem e com a função que é posta em ação quando isso ocorre - a função da criação. Da interpretação como abertura à significação, à interpretação como efeito do encontro do sujeito com o limite da linguagem, se impõem o saber-fazer com o gozo irrepresentável em detrimento de significá-lo. Esse é o caminho percorrido neste trabalho de tese por meio das construções teóricas organizadas em três capítulos dos quais seguem algumas conclusões.

No primeiro capítulo, por uma incursão no ensino de Sigmund Freud e de Jacques Lacan, ao buscar o percurso trilhado por eles sobre a diferença sexual e a maneira de situar o feminino na psicanálise, conclui-se que o feminino é um ponto central na teoria psicanalítica. As histéricas mostraram isso a Freud ao participarem, por meio de suas falas, da fundação da psicanálise com a descoberta do inconsciente instância psíquica que se dedica a armazenar os significantes do desejo e a letra de gozo. Foi ao localizar a estreita ligação entre os sintomas e a sexualidade, que Freud identificou a relação do sujeito com um desejo sempre insatisfeito e com um gozo insistente.

Ao desenvolver uma teoria da sexualidade atrelada a uma teorização sobre a estruturação psíquica, Freud destaca que, quando se trata do ser humano, a diferenciação sexual não se limita à questão anatômica, de órgãos sexuais femininos ou 
masculinos. De acordo com ele, a diferença sexual depende da situação psíquica que a envolve, ou seja, da maneira como o órgão é interpretado pelo desejo e pelo gozo em cada sujeito singularmente. A noção de falo é colocada no centro da estruturação psíquica como representante do sexo no inconsciente e é em relação a ele que o masculino e o feminino se definem: o masculino resolvendo-se com ele e o feminino ultrapassando-o.

Na teorização sobre o falo, Lacan afirma que ele é um significante, o que quer dizer que ele é a inscrição simbólica do sexo no inconsciente e que a marca diferencial do humano no que tangue ao sexual é, justamente, o vínculo indissociável com a linguagem - o fato de o sujeito padecer do significante. O significante - o falo - vem instalar no sujeito uma posição inconsciente em relação ao seu sexo, a significação será engendrada por cada sujeito na associação entre significantes em seu inconsciente, produzindo, por seu movimento, um efeito de significado.

A referência fálica não é suficiente para definir o feminino, é a indicação de Lacan, que inclina sua teorização sobre o feminino para um mais além do falo. Segundo ele, ocorre uma dissimetria no nível simbólico em relação à inscrição do masculino e do feminino no inconsciente, uma vez que o masculino ancora sua representação na simbologia do que já está lá nomeado de falo, enquanto o feminino não é todo representado por ele. O que faz Lacan afirmar que uma mulher é não-toda representada simbolicamente, pois a parte que excede à representação fálica, resta irrepresentável.

Situamos então a articulação entre o feminino e o irrepresentável como estando na base da definição do feminino. Há um gozo irrepresentável que se encontra mais além da lógica fálica que é especificamente feminino, o Outro gozo, formulado por Lacan nas fórmulas da sexuação. Desse gozo conclui-se que ele é suplementar em relação ao gozo fálico ao qual uma mulher também tem acesso. Conclui-se também que 
ele se situa em um impossível de dizer, indicado por Lacan como um gozo que se experimenta, mas que nada se fala sobre ele. Por estar localizado fora dos domínios da linguagem, no campo do real, o gozo feminino escapa à representação, percorrendo o corpo inteiro.

O irrepresentável é abordado no segundo capítulo e o percurso para situá-lo foi recorrer a noções que dão a ele um contorno, uma vez que é puro furo, lugar vazio, desertado pela palavra e pelo sentido. Sua posição entre o desejado e o obtido é da ordem de uma hiância, um espaço sempre aberto, onde impera a força do real na economia psíquica. Lacan afirma que a psicanálise é uma prática orientada para o real, esse núcleo duro das coisas, lugar do silêncio e do inassimilável. Essa parte constitui o núcleo central do inconsciente, núcleo real em torno do qual o inconsciente se estrutura como uma linguagem.

A forma de abordá-lo na clínica psicanalítica se dá por meio de buscar a instância da letra no inconsciente, porque a letra toca o real, ela traça uma borda entre o saber e o gozo marcando o lugar que no significante faz retorno, a parte da fala que escapa ao sentido, que resiste ao saber. Ao dizer que a letra faz da fronteira entre o real e o simbólico um litoral, quer dizer que enquanto o simbólico avança em direção ao real em uma tentativa de dizê-lo - e esse é o movimento da linguagem -, a letra mantém o traçado que sinaliza que o simbólico nunca será capaz de fazê-lo, pois há um limite à linguagem.

Esse limite é evidenciado na comunicação na forma de uma decalagem. Quando se trata do ser falante há uma decalagem entre o que se diz e o que se escuta, bem como entre o que se escreve e o que se lê, sendo a interpretação o que torna possível o desdobramento do discurso - passar do que se diz ao que se escuta só é possível interpretando. Aqui, fala-se de uma interpretação elementar, linguageira, aquela que 
permite a comunicação. Na experiência analítica também falamos de interpretação, dispositivo básico de intervenção, mas sua ação se desdobra na contramão da comunicação.

A interpretação, em psicanálise, assume um estatuto mais de equivocação do que de compreensão, é o que propõe a regra da associação livre, uma aposta no fluxo de palavras e nas substituições, mais que no sentido da história contada. A função da fala na experiência analítica não é a comunicação, sua função é evocar, entoar e não informar, o que aproxima a fala analítica da função poética da linguagem, onde os efeitos ultrapassam a comunicação. Retomamos o que diz Jacques-Alain Miller (2012) sobre a escrita de Mallarmé, uma escrita que oculta progressivamente o significado, fazendo a significância irradiar ainda mais em estilo de enigma, pois a significância se abre a partir do momento em que o significante funciona como letra, separado do seu valor de significação.

No terceiro capítulo, elegemos a articulação da psicanálise com a arte, especialmente com a poesia, por encontrar nesse campo mecanismos de linguagem e de criação que apontam para as vias que a psicanálise busca em sua intervenção clínica. Ao percorrer a obra freudiana, nos deparamos com as sucessivas convocações que Freud faz à criação artística como uma via de abordagem e captação da subjetividade humana. A investigação a respeito das fantasias, onde Freud traça uma aproximação entre a criação da fantasia e o trabalho do escritor criativo aponta que, assim como na fantasia, a escrita criativa não é um indicativo da realidade, entre ela e a realidade há uma hiância, lugar onde se situa o trabalho propriamente criativo, de uma criação por meio da linguagem na medida em que os seus elementos são rearranjados de uma forma singular a ponto de parecer criar um mundo próprio. 
Soltar as amarras da linguagem é o que Lacan propõe ao convocar a poesia como interlocutora na prática analítica, pois a poesia faz um uso particular do sistema linguístico como se houvesse uma gramática poética, onde a forma tem grande importância e prevalece sobre o conteúdo. Por meio de combinações estéticas, o poema marca uma lacuna entre o som e o sentido, evidenciando o lugar do non-sense. Assim, a palavra é tomada por seu valor de letra, quer dizer, fora do sentido e a possibilidade de significação fica a cargo do leitor que pode agregar algo relativo à sua própria fantasia. É assim que a função poética da linguagem mostra como uma palavra pode ter um valor de letra.

$\mathrm{Na}$ experiência analítica, o psicanalista é convocado a operar um forçamento no estatuto simbólico da linguagem para fazer surgir um efeito poético, efeito que é conseguido a partir dos jogos com a língua, da equivocação do significante até que ele possa funcionar como letra, palavra nua, fora do sentido. A prática da letra na psicanálise coloca em cena a poética enquanto função que permite um efeito de verdade, pois ela trabalha na trama do simbólico com o real, convocando o irrepresentável, incluindo, na lei do significante, o valor de gozo.

Uma interpretação analítica que busca inspiração na palavra poética não opera visando a uma produção de sentido, sua função, ao contrário, é produzir uma redução do sentido, como do significante à letra, pois o non-sense radical da letra toca o real. $\mathrm{O}$ equívoco e os jogos de palavras são modos de intervenção que buscam tocar o nonsense, o fora do sentido e com isso bordejar o furo, o buraco estrutural da linguagem.

Para Lacan, esse buraco estrutural é um furo no saber sobre a relação entre os sexos, um impossível de dizer que coloca em função a letra por ela se situar especialmente sobre a borda do furo no saber, podendo articular diante da impossibilidade de significar. O irrepresentável do gozo feminino está localizado nesse 
buraco, vimos que a função poética é capaz de engendrá-lo na clínica psicanalítica: a função poética de subversão da linguagem e, também, a função poética de criação diante do vazio instaurado pelo irrepresentável.

Concluímos que a produção deste trabalho de tese é resultado de um esforço de pesquisa, articulação e posicionamento diante de temas cruciais ao trabalho analítico. Buscamos tecer uma leitura sobre o feminino a partir da articulação com a noção de irrepresentável, apontando consequências clínicas. Apresentamos algumas indicações em relação ao estatuto da fala e da linguagem na clínica psicanalítica e destacamos, em especial, a função poética da linguagem como possibilidade de articular o real irrepresentável do gozo feminino. 


\section{REFERÊNCIAS}

André, S. (1994). O que quer uma mulher? Rio de Janeiro: Zahar.

Álvares, C. (2001). O literário e o irrepresentável: A escrita literária, segundo Pascal Quignard. In IV Congresso Internacional da Associação Portuguesa de Literatura Comparada.

Barros, M. (2007). O livro das ignorãças. Rio de Janeiro: Record.

Barros, M. (2008). Livro sobre nada. Rio de Janeiro: Record.

Barros, M. (2010). Menino do mato. São Paulo: Leya.

Branco, L. C. (2000). Os absolutamente sós - Llansol - A letra - Lacan. Belo Horizonte: Autêntica; FALE/UFMG.

Bruno, P. (2007). L'occulte et le réel: Critique de l'initiation. Eres Psychanalyse, n 10 , p. 33-40.

Chatelard, D. S. (2005). O conceito de objeto na psicanálise: do fenômeno à escrita. Brasília: Editora Universidade de Brasília.

Dafunchio, N. S. (2013). Seminários: Clínica da Sexução, Salvador, BA; Inibição, Sintoma e Angústia: uma clínica nodal das neuroses, Recife, PE. Salvador: IPB

Duras, M. (1986). O Deslumbramento (Le ravissement de Lol. V. Stein). Rio de Janeiro: Nova Fronteira.

Eco, U. (2003). Ensaios sobre a Literatura. Rio de Janeiro: Record.

Encontro com Lacan. Direção: Gerard Miller. Paris: INA - Institut National de l'Audiovisuel, 2011. Título original: Rendez-vous chez Lacan.

Freud, S. (1987). Histeria. Edição Standard Brasileira das Obras Psicológicas Completas de Sigmund Freud (Vol. I). Rio de Janeiro: Imago. (Originalmente publicado em 1988).

Freud, S. (1987). Algumas considerações para um estudo comparativo das paralisias motoras orgânicas e histéricas. Edição Standard Brasileira das Obras Psicológicas Completas de Sigmund Freud (Vol. I). Rio de Janeiro: Imago. (Originalmente publicado em 1893).

Freud, S. (1987). Estudos sobre a Histeria. Edição Standard Brasileira das Obras Psicológicas Completas de Sigmund Freud (Vol. II). Rio de Janeiro: Imago. (Originalmente publicado em 1893-1895). 
Freud, S. (1987). Projeto para uma psicologia científica. Edição Standard Brasileira das Obras Psicológicas Completas de Sigmund Freud (Vol. I). Rio de Janeiro: Imago. (Originalmente publicado em 1950 [1895]).

Freud, S. (1987). A interpretação dos sonhos. Edição Standard Brasileira das Obras Psicológicas Completas de Sigmund Freud (Vol. IV e V). Rio de Janeiro: Imago. (Originalmente publicado em 1900).

Freud, S. (1987). Três Ensaios sobre a teoria da sexualidade. Edição Standard Brasileira das Obras Psicológicas Completas de Sigmund Freud (Vol. VII). Rio de Janeiro: Imago. (Originalmente publicado em 1905).

Freud, S. (1987). Personagens psicopáticos no palco. Edição Standard Brasileira das Obras Psicológicas Completas de Sigmund Freud (Vol.VII). Rio de Janeiro: Imago. (Originalmente publicado em 1905-1906).

Freud, S. (1987). Delírios e Sonhos na Gradiva de Jensen. Edição Standard Brasileira das Obras Psicológicas Completas de Sigmund Freud (Vol. IX). Rio de Janeiro: Imago. (Originalmente publicado em 1907 [1906]).

Freud, S. (1987). Escritores Criativos e Devaneios. Edição Standard Brasileira das Obras Psicológicas Completas de Sigmund Freud (Vol. IX). Rio de Janeiro: Imago. (Originalmente publicado em 1908 [1907]).

Freud, S. (1987). Moral sexual civilizada e doença nervosa moderna. Edição Standard Brasileira das Obras Psicológicas Completas de Sigmund Freud (Vol. IX). Rio de Janeiro: Imago. (Originalmente publicado em 1908).

Freud, S. (1987). O narcisismo: uma introdução. Edição Standard Brasileira das Obras Psicológicas Completas de Sigmund Freud (Vol. XIV). Rio de Janeiro: Imago. (Originalmente publicado em 1914).

Freud, S. (1987). O Inconsciente. Edição Standard Brasileira das Obras Psicológicas Completas de Sigmund Freud (Vol. XIV). Rio de Janeiro: Imago. (Originalmente publicado em 1915).

Freud, S. (1987). O Estranho. Edição Standard Brasileira das Obras Psicológicas Completas de Sigmund Freud (Vol. XVII). Rio de Janeiro: Imago. (Originalmente publicado em 1919).

Freud, S. (1987). A organização genital infantil: uma interpolação na teoria da sexualidade. Edição Standard Brasileira das Obras Psicológicas Completas de Sigmund Freud (Vol. XIX). Rio de Janeiro: Imago. (Originalmente publicado em 1923).

Freud, S. (1987). A questão da análise leiga. Edição Standard Brasileira das Obras Psicológicas Completas de Sigmund Freud (vol. XX). Rio de Janeiro: Imago. (Originalmente publicado em 1926). 
Freud, S. (1987). O Humor. Edição Standard Brasileira das Obras Psicológicas Completas de Sigmund Freud (Vol. XXI). Rio de Janeiro: Imago. (Originalmente publicado em 1927).

Freud, S. (1987). O mal-estar na civilização. Edição Standard Brasileira das Obras Psicológicas Completas de Sigmund Freud (Vol. XXI). Rio de Janeiro: Imago. (Originalmente publicado em 1930).

Freud, S. (1987). Sexualidade feminina. Edição Standard Brasileira das Obras Psicológicas Completas de Sigmund Freud (Vol. XXI). Rio de Janeiro: Imago. (Originalmente publicado em 1931).

Freud, S. (1987). Novas conferências introdutórias sobre psicanálise: feminilidade. Edição Standard Brasileira das Obras Psicológicas Completas de Sigmund Freud (Vol. XXII). Rio de Janeiro: Imago. (Originalmente publicado em 1933[1932]).

Hilst, H. (1999). Do amor. São Paulo: Edith Arnhold/Massao Ohno.

Hilst, H. (2004). Cantares. São Paulo: Globo.

Jorge, M. A. C. (2008). Fundamentos da psicanálise de Freud a Lacan. Rio de Janeiro: Zahar.

Julien, P. (2009). O fim de uma sessão. In Trabalhando com Lacan. Rio de Janeiro: Zahar.

Kehl, M. R. (1996). A mínima diferença: masculino e feminino na cultura. Rio de Janeiro: Imago.

Kehl, M. R. (1998). O irrepresentável existe? In Psicanálise e Literatura, Revista da Associação Psicanalítica de Porto Alegre, n¹5, pp. 66-74.

Lacan, J. (1952/2008). O mito individual do neurótico ou poesia e verdade na neurose. Rio de Janeiro: Zahar.

Lacan, J. (1953/1998). Função e campo da fala e da linguagem. In Escritos. Rio de Janeiro: Zahar.

Lacan, J. (1953-1954/2009). O Seminário, livro 1: os escritos técnicos de Freud. Rio de Janeiro: Zahar.

Lacan, J. (1955-1956/2002). O Seminário, livro 3: as psicoses. Rio de Janeiro: Zahar.

Lacan, J. (1957/1998). A instância da letra no inconsciente ou a razão desde Freud. In Escritos. Rio de Janeiro: Zahar.

Lacan, J. (1957-1958/1999). O Seminário, livro 5: as formações do inconsciente. Rio de Janeiro: Zahar.

Lacan, J. (1958/1998). A significação do falo. In Escritos. Rio de Janeiro: Zahar. 
Lacan, J. (1959-1960/2008). O Seminário, livro 7: a ética da psicanálise. Rio de Janeiro: Zahar.

Lacan, J. (1960/1998). Diretrizes para um congresso sobre a sexualidade feminina. In Escritos. Rio de Janeiro: Zahar.

Lacan, J. (1962-1963/2005). O Seminário, livro 10: a angústia. Rio de Janeiro: Zahar.

Lacan, J. (1964/1998). O Seminário, livro 11: os quatro conceitos fundamentais da psicanálise. Rio de Janeiro: Zahar.

Lacan, J. (1965/2003). Homenagem a Marguerite Duras pelo arrebatamento de Lol V. Stein. In Outros escritos. Rio de Janeiro: Zahar.

Lacan, J. (1966/1998). A ciência e a verdade. In Escritos. Rio de Janeiro: Zahar.

Lacan, J. (1971/2003). Liturratera. In Outros escritos. Rio de Janeiro: Zahar.

Lacan, J. (1971/2009). O Seminário, livro 18: de um discurso que não fosse semblante. Rio de Janeiro: Zahar.

Lacan, J. (1971-1972/2011). Estou falando com as paredes. Rio de Janeiro: Zahar.

Lacan, J. (1972-1973/1985). O Seminário, livro 20: mais, ainda. Rio de Janeiro: Zahar.

Lacan J. (1976-1977). Le Séminaire, Livre XXIV, L'insu que sait de l'une-bévue s'aile à mourre. Version AFI, publication hors commerce, interne à l'Association freudienne internationale. Inédito.

Lispector, C. (1978). Um sopro de vida; Pulsações. Rio de Janeiro: Nova Fronteira.

Magno, M. D. (1977). Senso Contra Censo Arte e Psicanálise. Rio de Janeiro: Tempo Brasileiro.

Mandil, R. (2003). Os efeitos da letra: Lacan leitor de Joyce. Opção lacaniana, n³. Rio de Janeiro/ Belo Horizonte: Contra Capa Livraria/ Faculdade de Letras UFMG.

Mannoni, M. (1999). Elas não sabem o que dizem: Virgínia Woolf, as mulheres e a psicanálise. Rio de Janeiro: Zahar.

Mannoni, O. (1992). Um espanto tão intenso: a vergonha, o riso, a morte. Rio de Janeiro: Campus.

Marcos, C. (2011). Mãe e filha - da devastação e do amor. In Revista Tempo Psicanalítico. Psicanálise e Cultura, vol. 43, n² 2. Rio de Janeiro.

Maurano, D. (2010). Para que serve a psicanálise? In Coleção passo-a-passo, vol. 21. Rio de Janeiro: Zahar. 
Miller, J-A. (1997). Lacan Elucidado: palestras no Brasil. Rio de Janeiro: Jorge Zahar.

Miller, J-A. (2012). O escrito na fala. In Opção lacaniana Online, ano 3, nº 8. Rio de Janeiro.

Pacheco, A. L. P. (2012). Por uma prática sem valor: a suficiência e a conveniência poética do psicanalista. In Stylus Revista de Psicanálise, nº $^{\circ}$ 25. Rio de Janeiro.

Pesenti-Irrmann, M. (2006). La mère e le féminin. In La clinique lacanienne, $\mathrm{n}^{\circ}$ 11, pp. $65-75$.

Pommier, G. (1987). A exceção feminina: os impasses do gozo. Rio de Janeiro: Zahar.

Quinet, A. (2005). A lição de Charcot. Rio de Janeiro: Zahar.

Quintana, M. (2007). Da preguiça como método de trabalho. São Paulo: Globo.

Ramos, C. (2013). A interpretação como valor de verdade e como função poética. In Stylus Revista de Psicanálise, $\mathrm{n}^{\circ}$. 26. Rio de Janeiro.

Ribeiro, A. T. (2000). O escrever e o ler: prática da letra e desejo em prática. In $A$ Prática da Letra, ano XIX, nº. 26. Rio de Janeiro: Escola da Letra Freudiana.

Rivera, T. (2005). Gesto analítico, ato criador. Duchamp com Lacan. In Pulsional revista de psicanálise, ano XVIII, $\mathrm{n}^{\circ}$ 184. São Paulo.

Sauret, M-J. (2006). Féminin et lien social. In La clinique lacanienne, 2006/2, n 11, pp. 91-108.

Saussure, F. (1972). Curso de lingüística geral. São Paulo: Cultrix.

Sobral, P. O. (2008). Psicose e Escrita: a inscrição de um sujeito. Dissertação de mestrado não-publicada, Universidade Federal da Paraíba, Paraíba, Brasil.

Soler, C. (2005). O que Lacan dizia das mulheres. Rio de Janeiro: Zahar.

Vieira, M. A. (2013). Mulher: figura impossível (ou "No litoral”). In Opção Lacaniana, $n^{\circ} .65$, pp. 69-72. São Paulo: EBP.

Zalcberg, M. (2003). A relação mãe e filha. Rio de Janeiro: Campus.

Zalcberg, M. (2007). Amor paixão feminina. Rio de Janeiro: Elsevier. 